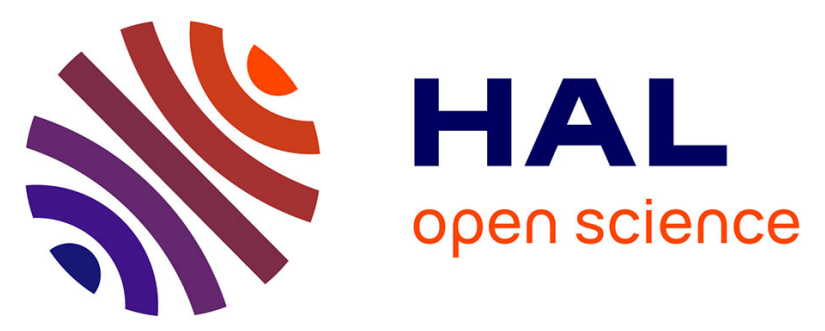

\title{
Ordovician 40Ar/39Ar phengite ages from the blueschist-facies Ondor Sum subduction-accretion complex (Inner Mongolia) and implications for the early Paleozoic history of continental blocks in China and adjacent areas
}

Koenraad de Jong, Wenjiao Xiao, Brian F. Windley, Hideki Masago, Ching-Hua Lo

\section{- To cite this version:}

Koenraad de Jong, Wenjiao Xiao, Brian F. Windley, Hideki Masago, Ching-Hua Lo. Ordovician $40 \mathrm{Ar} / 39 \mathrm{Ar}$ phengite ages from the blueschist-facies Ondor Sum subduction-accretion complex (Inner Mongolia) and implications for the early Paleozoic history of continental blocks in China and adjacent areas. American journal of science, 2006, 306 (10), pp.799-845. 10.2475/10.2006.02 . hal-00139003

\section{HAL Id: hal-00139003 \\ https://hal-insu.archives-ouvertes.fr/hal-00139003}

Submitted on 9 Oct 2008

HAL is a multi-disciplinary open access archive for the deposit and dissemination of scientific research documents, whether they are published or not. The documents may come from teaching and research institutions in France or abroad, or from public or private research centers.
L'archive ouverte pluridisciplinaire HAL, est destinée au dépôt et à la diffusion de documents scientifiques de niveau recherche, publiés ou non, émanant des établissements d'enseignement et de recherche français ou étrangers, des laboratoires publics ou privés. 
Ordovician ${ }^{40} \mathrm{Ar} /{ }^{39} \mathrm{Ar}$ phengite ages from the blueschist-facies Ondor Sum subduction-accretion complex (Inner Mongolia) and implications for the early Paleozoic history of continental blocks in China and adjacent areas

\author{
Koen de Jong ${ }^{1,5}$ \\ Wenjiao Xiao ${ }^{2}$ \\ Brian F. Windley ${ }^{3}$ \\ Hideki Masago 4 \\ Ching-Hua Lo ${ }^{5}$
}

1. Institut des Sciences de la Terre d'Orléans

CNRS/INSU UMR 6113 Université d'Orléans

45067 Orléans 7 cedex 2

France

Email: Koen.deJong@univ-orleans.fr

Tel: +33 (0)238494646

Fax: +33 (0)2 38417308

2. State Key Laboratory of Lithosphere Tectonic Evolution, Institute of Geology and Geophysics, Chinese Academy of Sciences, Beijing 100029, China

3. Department of Geology, University of Leicester, Leicester LE1 7RH, UK

4. Japan Agency for Marine-Earth Science and Technology (JAMSTEC), Center for Deep Earth Exploration, 3173-25 Showa-machi, Kanazawa-ku, Yokohama, Kanagawa 236-0001, Japan

5. Argon Geochronology Laboratory

Department of Geosciences

National Taiwan University, Taipei 10699, Republic of China 
ABSTRACT. We obtained $453.2 \pm 1.8 \mathrm{Ma}$ and $449.4 \pm 1.8 \mathrm{Ma}(2 \sigma)$ laser step-heating ${ }^{40} \mathrm{Ar} /{ }^{39} \mathrm{Ar}$ plateau ages for phengite from quartzite mylonites from the blueschist-facies Ondor Sum subductionaccretion complex in Inner Mongolia (northern China). These ages are within error of the inverse isochron ages calculated using the plateau steps and the weighted mean ages of total fusion of single grains. The compositional change from glaucophane in the cores to crossite in the rims of blue amphiboles, as revealed by electron microprobe analysis, points to decompression, probably caused by progressive exhumation of the subducted material. The Late Ordovician ages were not affected by excess argon incorporation because in all likelihood the oceanic sediments were wet on arrival at the trench and free of older detrital mica. The ca. 450 Ma ages are, hence, interpreted as the time of crystallization during mylonitization under high fluid activity at fairly low temperatures. This means that accretion of the quartzite mylonite unit occurred about 200 Ma before final closure of the PaleoAsian Ocean, amalgamation of the Siberian, Tarim and North China cratons, and formation of the end-Permian Solonker suture zone.

We argue that the Early Paleozoic evolution of the Ondor Sum complex occurred along the northeastern Cimmerian margin of Gondwana, which was composed of micro-continents fringed by subduction-accretion complexes and island arcs. The later evolution took place during the building of the Eurasian continent following middle Devonian and younger rifting along the East Gondwanan margin and northward drift of the detached North China craton. An extensive review shows that this type of two-stage scenario probably also applies to the geodynamic evolution of other microcontinents like, South China, Tarim, a number of Kazakh terranes, Alashan, Qaidam and Kunlun, as well as South Kitakami and correlatives in Japan, and probably Indochina. Like the North China craton, these were bordered by Early Paleozoic subduction-accretion complexes, island arcs or contained calc-alkaline volcanic margins, like for example, the central Tienshan, North Qinling, North Qaidam-Altun, North Qilian and Kunlun belts in China, as well as the Oeyama and Miyamori ophiolites and Matsugadaira-Motai blueschist belt of Japan and the dismembered Sergeevka ophiolite of the southern part of the Russian Far East. This implies that a vast orogenic system, comprising an archipelago of micro-continents, seems to have existed along the Cimmerian margin of 
East Gondwana in Early Paleozoic time in which the ultrahigh-pressure metamorphism that characterizes the early evolution of many of the Asian micro-continents occurred. 


\section{INTRODUCTION AND AIM}

The Central Asian Orogenic Belt (CAOB) is a complex collage of island arcs, micro-continental fragments and remnants of oceanic crust, including small forearc and backarc basins, situated between the Siberian craton to the north and the Kazakhstan, North China (or Sino-Korean) and Tarim cratons in the south (Zonenshain, 1973; Zonenshain and others, 1990; Mossakovsky and others, 1994; Jahn and others, 2000; Filippova and others, 2001; Badarch and others, 2002; Kheraskova and others, 2003; Xiao and others, 2003; Jahn, 2004; fig. 1). The CAOB likely continues eastward as far as the Hida belt in Japan (fig. 1, loc. 11; Arakawa and others, 2000; Jahn and others, 2000) that was part of the Asian mainland before the Miocene (Maruyama and others, 1997). Although the southern margin of Siberia was the site of subduction-accretion tectonics from the Neoproterozoic on (Dobretsov, 2003; Dobretsov and others, 2003; Khain and others, 2003), the CAOB formed mainly during the Paleozoic by accretion of oceanic plate sediments and magmatic arcs, as well as by amalgamation of terranes of different type and derivation (Coleman, 1994; Didenko and others, 1994; Mossakovsky and others, 1994; Dobretsov and others, 1995; Buslov and others, 2001; Filippova and others, 2001; Badarch and others, 2002; Windley and others, 2002; Dobretsov, 2003; Kheraskova and others, 2003; Xiao and others, 2003, 2004a). This process was accompanied by emplacement of immense volumes of mafic and granitic magmas (Chen and others, 2000; Jahn and others, 2000; Wu and others, 2002; Jahn, 2004). The CAOB resulted from the closure of an oceanic basin (Mongolian seaway: Maruyama and others, 1997; Paleo-Asian Ocean: Xiao and others, 2003) by double subduction below the southern active margin of the Siberian craton and the northern margins of North China and Tarim (Wang and Liu, 1986). Li and Wu (1996) argued that intermixing of floras typical for the Siberian craton on the one hand and the North China and Tarim cratons on the other constrains their incipient collision as early Late Permian. Cope and others (2005) envisaged that convergence and ultimate collision resulted in a paleo-current reversal in North China due to the onset of uplift and creation of topography on the northern margin of the craton, from mid-Permian time on. The collision resulted in the formation of the Solonker suture zone, a major structure developed just north of the North China craton (Badarch and others, 2002) and Tarim craton (Xiao and others, 2004b), and that can be followed all along the CAOB from Kyrgyzstan in the west to the coastal area of the Sea of Japan in northernmost North Korea in the east (fig. 1). Different lines of evidence point to a suturing that occurred 
progressively later from west to east (Dobretsov, 2003; Xiao and others, 2004b; Cope and others, 2005). During the final stages of the collision crustal shortening was partitioned into vertical, ductile, strike-slip shear zones between the micro-continents that often reactivated older sutures, during the late Carboniferous to early Permian in the western part (Buslov and others, 2001, 2004) and the late Permian in the central part (Laurent-Charvet and others, 2003) of the orogen. Early Permian A-type granites, occurring in a narrow belt along the suture zone, formed as result of post-collisional slab break-off, and Late Triassic to Early Jurassic A-type granites from subsequent lithospheric delamination ( $\mathrm{Wu}$ and others, 2002). Triassic molassic sediments that overly weakly foliated to undeformed about 230-Ma old granite plutons (Wang and Liu, 1986; Chen and others, 2000) mark their cooling and exhumation, and herald the end of the collision and uplift of the orogen. A compilation by Wang and Liu (1986) and data obtained by the Bureau of Geology and Mineral Resources of Inner Mongolia (Nei Mongol) (BGMRIM, 1991) indicate that terrestrial sediments were deposited across the suture zone in early Jurassic time.

Şengör and others (1993) favored continuous, forearc subduction-accretion and arc collision along the southern margin of the Siberian craton. However, ophiolite belts in the CAOB have been interpreted alternatively as discrete suture zones between terranes, rather pointing to punctuated closure of multiple oceanic basins (Hsü and others, 1991; Mossakovsky and others, 1994; Buchan and others, 2002). Xiao and others (2003) proposed a model for the evolution of the CAOB with three main stages that are related to progressive two-way subduction of the Paleo-Asian Ocean: (1) early to mid-Paleozoic Japanese-type subduction-accretion, (2) a Permian Andean-stage when the two opposing margins became sufficiently consolidated, and (3) continent-continent collision, leading to the formation of the Solonker suture zone at the end of the Permian during the final closure of the Paleo-Asian Ocean due to its coeval southward and northward subduction beneath the Tarim and North China cratons and Siberia, respectively.

The $60-\mathrm{km}$ wide Erdaojing complex forms part of the Solonker suture zone in Inner Mongolia (fig. 2) and consists of tectonic mélanges with blocks of meta-chert, marble, and ultramafic-mafic rocks of blueschist-facies metamorphic grade (Tang, 1990; Xu and others, 2001). The latter authors obtained a ${ }^{40} \mathrm{Ar} /{ }^{39} \mathrm{Ar}$ age of $383 \pm 13 \mathrm{Ma}$ (mid-Devonian) on a sodic-amphibole from a blueschist block (fig. 2, for location). Recently, late Guadalupian (middle Permian) radiolarians have been found (Shang, 2004). The subduction-accretion complex can be compared to the Jilin complex that occurs northeast of the SinoKorean craton in northeastern China (Li, 2006). The suture has a multiple character, because it occurs 5 
within two opposing subduction-accretion complexes formed by two-way subduction (Xiao and others, 2003). Although the former controversy about the timing of the formation of the Solonker suture zone has been resolved as end-Permian (Chen and others, 2000; Wu and others, 2002; Xiao and others, 2003; Cope and others, 2005), the age and significance of the early accretionary stages are poorly known and understood. The Ondor Sum accretion-subduction complex offers a key opportunity to constrain the timing of the early accretion along the northern margin of the North China craton. Therefore, we applied the ${ }^{40} \mathrm{Ar} /{ }^{39} \mathrm{Ar}$ dating method to well-selected samples of blueschist-facies, phengite-bearing quartzitic mylonite in the Ulan Valley in the Ondor Sum region (figs. 2 and 3), where the best section through the subductionaccretion complex is exposed.

The ca. $450 \mathrm{Ma}^{40} \mathrm{Ar} /{ }^{39} \mathrm{Ar}$ ages that we obtained on phengites imply that ductile deformation in the Ondor Sum subduction-accretion complex took place some 200 Ma before the formation of the Late Permian Solonker suture zone. We argue that the Late Ordovician deformation and metamorphism took place along the margin of East Gondwana, parts of which, such as Tarim and the North and South China cratons, were rifted off in Late Paleozoic time and entered the Paleo-Asian Ocean as micro-plates, in part fringed by Early Paleozoic subduction-accretion complexes and island arcs.

\section{THE NORTHERN MARGIN OF THE NORTH CHINA CRATON}

The basement of the North China craton consists of Archean predominantly trondhjemitictonalitic-granodioritic gneisses and minor mafic igneous rocks, as well as Paleoproterozoic metasedimentary and igneous rocks, which are locally overlain by Neoproterozoic to Early Paleozoic passive margin sediments (Hsü and others, 1991; Zhao, 2001; Kusky and Li, 2003; Zhai and others, 2003, 2005; Jia and others, 2004). Cambrian to middle Ordovician platform carbonates are unconformably covered by Carboniferous-Permian strata (BGMRIM, 1991). Based on ${ }^{40} \mathrm{Ar} /{ }^{39} \mathrm{Ar}$ plateau ages of amphiboles from the Bayan Obo area (fig. 2), Chao and others (1997) postulated a regional metamorphic event that started at about $425 \mathrm{Ma}$ and continued until at least $395 \mathrm{Ma}$. By the end of the Carboniferous the northern side of the North China craton was an active continental margin into which Andean-type granites and granodiorites were intruded, onto which andesites, basalts, dacites, rhyolites were extruded, and tuffs were deposited (Xiao and others, 2003). The Late Carboniferous to Permian series contain detritus from both 
plutonic and metamorphic sources (polycrystalline quartz, feldspar and lithic fragments) that supplied detrital zircons with Archean-Paleoproterozoic and Late Paleozoic Sensitive High-Resolution Ion MicroProbe (SHRIMP) U-Pb ages (Cope and others, 2005). The latter, 425-275 Ma, age group increases in importance stratigraphically upward and reveals that the northern margin of North China was a continental margin arc already in the Silurian and which activity would last into Permian time (Cope and others, 2005). Late Paleozoic granite and granodiorite intrusions in the Precambrian basement of the northernmost North China craton (BGMRIM, 1991; Chao and others, 1997; figs. 2 and 10 of Xiao and others, 2003) probably form the source that is being progressively eroded in the terminal Paleozoic (Cope and others, 2005). The Carboniferous-Permian strata exposed near the most northern limit of the Archean basement are deformed into a series of tight north-vergent overturned to isoclinal folds, which are unconformably overlain by Early Jurassic fluvial-lacustrine sediments (Cope and others, 2005).

The Chifeng-Bayan Obo fault (fig. 2) is widely regarded as the northern boundary of the North China craton (Wang and Liu, 1986; Shao, 1989; Tang and Yan, 1993; Bai and others, 1993a, b). A number of Early Paleozoic island arcs occur to the north of the fault. The Ulan arc formed within the Ondor Sum subduction-accretion complex during this period, as part of a north-dipping, oceanward-directed subduction system along the northern margin of the craton, and subsequently, the Bainaimiao arc formed as a result of southward subduction (fig. 4; Xiao and others, 2003). The latter arc consisted of calc-alkaline tholeiitic basalts to minor felsic lavas, alkaline basalts, agglomerates, volcanic breccias and tuffs, as well as gabbros, granodiorites and granites (Hu and others, 1990). Zircon from a granodiorite porphyry has a U-Pb age of about $466 \mathrm{Ma}$ and a muscovite from a granite yielded a K-Ar age of ca. $430 \mathrm{Ma}$ (Zhang and Tang, 1989). Xiao and others (2003) argued that the high initial strontium isotope ratio $\left({ }^{87} \mathrm{Sr}^{86} \mathrm{Sr}_{\mathrm{i}}=0.7146\right)$ of granites (Shao, 1989) and the $\varepsilon N d$ value of $2.4 \pm 1.7$ of granodiorite (Nie and Bjørlykke, 1999) imply that the Bianaimiao arc was formed by mixing between mantle-derived and crustal rocks in an active continental Cordilleran-type margin, rather than in an island arc, as commonly thought. A 20-30 km wide and $120 \mathrm{~km}$ long east-trending belt occurring about $50 \mathrm{~km}$ south of Bayan Obo (fig. 2) contains ca. 455 Ma-old granitic plutonic rocks that intrude Proterozoic metasediments (Chao and others, 1997). The ca. $430 \mathrm{Ma}$ K-Ar muscovite from a granite probably reflects the cooling of the Bainaimiao arc. The occurrence of shallowmarine clastic sediments and carbonates (with late Silurian fossils corals) on top of early Paleozoic granites 
in the western Ondor Sum region (Wang and Liu, 1986) constrains the exhumation of the Bainaimiao-type magmatic rocks, which may point to the extinction of the arc. In the Silurian, Devonian and Carboniferous no island arcs were generated and accreted to the northern margin of the North China craton (Xiao and others, 2003).

\section{ONDOR SUM SUBDUCTION-ACCRETION COMPLEX}

Isolated outcrops of ophiolites occur around Ondor Sum, in an area of about $70 \mathrm{~km}$ along strike associated with high-pressure metamorphic rocks, and further eastward in the area of Kedenshan and along the northern banks of the Xar Moron River (fig. 2). These rocks form part of the Ondor Sum subductionaccretion complex (fig. 2), which incorporates the Ondor Sum Group (Zhang and Wu, 1998), Ondor Sum Ophiolite Belt (Wang and Liu, 1986), Wentermiao (Tang and others, 1983) or Wendurmiao (Hu and others, 1990) Group or the Ondor Sum magmatic-metamorphic complex (Zhai and others, 2003). The subductionaccretion complex comprises Early Paleozoic rocks (Xiao and others, 2003) that have been thrust onto the continental margin of the North China craton. The Mesoproterozoic amphibolite-facies orthogneisses and supracrustal rocks as well as Neoproterozoic greenstones described by Zhai and others (2003) probably belong to this basement.

We have structurally subdivided the Ondor Sum complex at its type locality in the Ulan Valley (also known as: Ulangou, Wulan valley, or Wulangou) northeast of Ondor Sum into three units. These are, from south to north (fig. 3), in order of increasing intensity of deformation and structural position: Unit 1 (undeformed pillow basalt with a cover of chert and clastics), Unit 2 (a series of volcanic rocks) and Unit 3 (mylonitic meta-chert with lenses of ocean-floor derived lithologies). The three units of the subductionaccretion complex are described below in more detail.

Unit 1

Unit 1 comprises about 600 meters of undeformed pillow basalt, in which lensoid bodies of gabbro and limestone occur imbricated (fig. 3). Pillows are up to 30-50 cm long, have vesicular chilled margins and well-preserved amygdaloids filled wth carbonate, chlorite and occasionally albite. Pillow breccias and hyaloclastites, with centimeter-size lava fragments, are found near the bottom of the lavas. 
Many flows have a shear foliation parallel to the bedding of the pillows. The basalts are considered to be of MORB-type, on the basis of their major and trace elements compositions (Tang, 1992; Wu and others, 1998). The basalts are characterized by the metamorphic assemblage: lawsonite + albite + pumpellyite + chlorite + aragonite + calcite + quartz + epidote; lawsonite occurs mainly in the cores of pillows and decreases in abundance outward (Yan and others, 1989).

The series of pillow basalt form the upper part of a locally preserved ophiolite sequence of, from bottom to top; serpentinized harzburgite and dunite, cumulate gabbro, and diabase (Wang and Liu, 1986), developed to the south of the area displayed in figure 4. The ultramafic rocks have the metamorphic mineral assemblage: talc + calcite + magnesite + chlorite + magnetite (Yan and others, 1989). Gabbros contain: omphacite $(\mathrm{Jd} \% 35-25)+$ chlorite + epidote + pumpellyite + albite + titanite + quartz as highpressure metamorphic assemblage (Yan and others, 1989).

The basalts in the uppermost part of unit 1 are covered by a thrust-imbricated, but stratigraphically intact succession of red to purple-colored chert and overlying sandstone (figs. 4, 5). Chert may contain msize lenses of serpentinite and magnetite-pyrolusite-quartz rock. Chert has yielded fossil sponge spicules, Hyolithes, Monoplaco-phora, radiolaria, acritarchs and spores, indicative of a Late Precambrian to Cambrian age (Peng, 1984; Wang and Liu, 1986). Xiao and others (2003) interpreted the thrust duplex on the ophiolitic rocks as representing the ridge-trench transition in ocean plate stratigraphy.

The north-dipping contact zone with the overlying lava series of unit 2 is made up of a $200-250 \mathrm{~m}$ thick zone in which pillow basalts, gabbro and more or less serpentinized harzburgite occur intimately imbricated (fig. 5). At the uppermost thrust contact ultramafic rocks are transformed into talc schists or magnesite-chlorite schists, pointing to pervasive retrogressive hydration.

Unit 2

Unit 2 contains calc-alkaline basalts, andesites, dacites, rhyolites and bedded pyroclastic tuffs. The unit is separated from the structurally underlying unit 1 and overlying unit 3 by a north-dipping thrust faults (fig. 3). Xiao and others (2003) regarded this series of volcanic rocks as a relic of a dismembered island arc that was incorporated into the subduction-accretion complex. 
Unit 3

Unit 3 occupies the structurally highest tectonic position and is the principal target of our study. It consists of a $c a .400 \mathrm{~m}$-thick series of phengite-bearing quartzitic mylonites that are typically reddened due to the presence of hematite. The mylonites contain a well-developed, moderately northward plunging mineral and stretching lineation (fig. 3). The regional foliation is deformed into open and upright folds with wavelengths in the order of $50 \mathrm{~m}$ and axes that shallowly plunge in approximately east- and westward directions. The mylonites contain lenses, which are up to 200 meters across, of several different lithologies such as: meta-basaltic greenschist and blueschist (fig. 3), chlorite schist and chlorite-magnetite-epidote schist, meta-chert, magnetite-pyrolusite-quartz rock, quartz-pyrite-hematite rock, quartz-sericite schist, Kwhite mica-rich quartzitic schist and marble. Some quartzites contain deerite, glaucophane, hematite, magnetite, minnesotaite, piemontite and stilpnomelane (Yan and others, 1989). Phase equilibria point to temperatures of $250-350^{\circ} \mathrm{C}$ and pressures in the order of 0.60-0.75 GPa (Tang and Yan, 1993).

Xiao and others (2003) considered the quartzites of unit 3 to be derived from ocean-floor chert enriched in Fe and Mn and imbricated with slices of oceanic basalt and gabbro during subduction.

\section{Age constraints}

An number of small bodies of different leucocratic rocks, like fine-grained plagiogranite and granophyric trondhjemite, occur associated with the gabbroic rocks and pillow lavas in the Ondor Sum region between Tulinkai and Deyenqimiao to the east of the Ulan Valley (Zhao and Li, 1987; Tang, 1990; Jian and others, 2006). The latter authors obtained U-Pb SHRIMP ages on zircon from these rocks: $477 \pm$ $10 \mathrm{Ma}$ (ophiolite), $477 \pm 6 \mathrm{Ma}$ (low-K rhyolites), $467 \pm 12 \mathrm{Ma}$ (trondhjemite associated with island arc tholeiites) and $457 \pm 10 \mathrm{Ma}$ (adakite). These ages are much younger, but within error of the $\mathrm{Rb}$-Sr wholerock age of $509 \pm 40 \mathrm{Ma}$ that is often quoted for a meta-basalt of unit 1 (for example, Yan and others, 1989; Tang, 1990). However, analytical data for this particular sample are not given and it is not stated where it is taken, rendering its value somewhat uncertain.

${ }^{40} \mathrm{Ar} /{ }^{39} \mathrm{Ar}$ isochron ages of $446 \pm 15 \mathrm{Ma}$ and $426 \pm 15 \mathrm{Ma}$ are often quoted for glaucophane (for example, Zhang and Liou, 1987; Yan and others, 1989; Tang and Yan, 1993). In spite of the fact that these dates are the only available isotopic constraints on the timing of the high-pressure metamorphism of the 
Ondor Sum complex their meaning is uncertain, because analytical data, descriptions of the samples and of their provenance are lacking,

The late Silurian shallow-marine clastic sediments and carbonates that unconformably overlie the ophiolites, blueschists and cherts in the central part of the Ondor Sum region (Tang and others, 1983) do not place tight age constraints on the timing of exposure at the surface of the subduction-accretion complex.

\section{SAMPLE DESCRIPTION, PETROGRAPHY AND MINERAL CHEMISTRY}

The dated mica-bearing quartzites of unit 3 (fig. 3) are intensely foliated and lineated, fine-grained mylonites. The pronounced mineral and stretching lineation plunges moderately to the north. IM-2 has a brick red color, whereas IM-5 is more brownish due to some secondary limonitization. The main minerals in both mylonites are quartz and (minor) phengite, whereas hematite is the major accessory phase. The thoroughly dynamically recrystallized quartz has a grain size of $<200 \mu \mathrm{m}$. The mylonite foliation is formed by an alternation of red, hematite-rich and milky white, hematite-free quartz layers at the scale of less than a millimeter. The hematite-free layers are interpreted as quartz veins that were rotated parallel to the mylonite foliation as a result of the intense elongation of the rocks during their ductile deformation. Less deformed folded and boudinaged quartz veins that are discordant to the mylonite foliation also occur. Foliation boudinage resulted in an anastomosing foliation. Cross cutting, mm-thick quartz veins occur subperpendicular to both foliation and lineation, which contain fibrous crystals with their c-axis parallel to the stretching lineation, pointing to a crack-seal mechanism during brittle extension. The occurrence of different generations of progressively stronger deformed quartz veins points to alternating phases of brittle and ductile deformation. These are probably associated with variations in strain rate and/or fluid pressure. Yellowish green phengite occurs in lozenge-shaped aggregates of a few millimeters long between anastomosing quartz layers, but may also be extremely elongated forming several centimeter-long and highly attenuated lenses. These structures are interpreted as micro-boudins.

Blueschist sample IM-19 is taken from the foliated and lineated margin of a 70 m-diameter metagabbro/leucogabbro lens imbricated in the quartzite mylonite (fig. 3). It is a fine-grained rock (fig. 6) with a weakly developed planar and linear fabric, containing the following mineral paragenesis: Na-amphibole + 
stilpnomelane + chlorite + plagioclase + phengite + calcite + dolomite + quartz, with accessory titanite and magnetite.

The sodic-amphiboles occur as $\sim 0.8 \mathrm{~mm}$-long, rectangular or flaky porphyroblasts with a distinctive deep blue to pale violet pleochroism. They are optically and compositionally zoned, usually with deep bluish cores, which seems to be common for the sodic-amphiboles in the area (Yan and others, 1989). Occasionally, the amphiboles have more irregular and complicated spotted and/or oscillatory zoning patterns. A small number of sodic-amphiboles have rectangular mineral inclusions, presumed to be relict igneous augite, some of which are boudinaged (fig. 6). Electron microprobe analyses show that Naamphibole varies in composition from glaucophane in the cores to crossite in the rims (fig. 7). The cores generally have a slightly higher $\mathrm{Fe}^{2+} / \mathrm{Mg}$ ratio, higher $\mathrm{M} 4$ site $\mathrm{Na}(>1.8)$ and $\mathrm{Al}(\mathrm{VI})$ contents, but a lower $\mathrm{Fe}^{3+}$ content than the rims (table 1, fig. 7). The blue amphibole that seals the pulled-apart augite (fig. 6) has a crossitic composition.

Plagioclase is almost pure albite $(\mathrm{Ab}>99$; table 2$)$ and forms irregular porphyroblasts. The main matrix minerals are: pale-green stilpnomelane that occurs abundantly as aggregates of tiny flakes or laths, relatively rare chlorite, and occasional K-white mica that forms tiny laths. Electron microprobe analysis demonstrates that the K-white mica in this sample is a phengite with $1.67 \mathrm{Al}$ pfu and $3.64 \mathrm{Si}$ pfu and a negligible paragonite component (table 2). Magnetite is the major accessory phase, whereas titanite, although rare, occurs as relatively large grains up to $1.2 \mathrm{~mm}$ long.

Calcite and dolomite are abundant in the matrix and occur as anhedral crystals that cement cracks and grain boundaries of other matrix minerals, suggesting secondary infiltration of a $\mathrm{CO}_{2}$-rich fluid. Both carbonates have dolomitic rims of higher $\mathrm{Mg}$ composition (table 2). The $\mathrm{Ca} /(\mathrm{Ca}+\mathrm{Mg}$ ) ratio in the cores of calcite and dolomite is ca. 0.01 and 0.31 , respectively, whereas the ratio in the rim of both is about 0.35 0.38. Both minerals have a small siderite component $\left(\mathrm{X}_{\mathrm{Sd}}<0.1\right)$, which shows a concomitant increase with magnesite in the rim.

The mineral paragenesis of IM-19 points to high-pressure metamorphism related to subduction, but it does not permit a quantitative estimate of its pressure-temperature condition. At first sight the maximum pressure seems constrained by the stability of albite instead of sodic-pyroxene and the lack of lawsonite. Yan and others (1989) noted that lawsonite and glaucophane never occur in the same assemblage in the high-pressure metamorphic rocks in the Ulan Valley. Absence of lawsonite might also be 12 
partly due to the presence of an elevated $\mathrm{CO}_{2}$ component in the metamorphic fluid in this particular sample, which strongly reduces the stability field of the mineral (Nitsch, 1972). Glaucophane cores of sodicamphiboles imply relatively high-pressure conditions during the prograde stage. The increase of $\mathrm{Fe}^{3+}$, in combination with the decrease in the alumina and $\mathrm{Na}(\mathrm{M} 4)$ contents and the $\mathrm{Fe}^{2+} / \mathrm{Mg}$ ratio, toward grain rims points to decreasing pressure and increasing temperature (Brown, 1977; Maruyama and others, 1986) during advanced metamorphic stages. The decompression was most likely due to progressive exhumation of the subducted material. The sealing of pulled-apart augite (fig. 6) by blue amphibole of crossitic composition instead of glaucophane indicates that exhumation occurred during deformation.

\section{${ }^{40} \mathrm{Ar}{ }^{39} \mathrm{Ar}$ DATING RESULTS}

${ }^{40} \mathrm{Ar} /{ }^{39} \mathrm{Ar}$ dating of phengite occurred by incremental heating of $64-100 \mu \mathrm{m}$ diameter grains with a defocused, continuous ultraviolet laser beam. Fusion was achieved in the final step by beam focusing. All grains of IM-5 were step-heated, whereas splits of sample IM-2 were step-heated separately in two experiments (IM-2a and IM-2b). A number of grains of each sample were dated by total fusion too. The ${ }^{40} \mathrm{Ar} /{ }^{39} \mathrm{Ar}$ analytical data are listed in tables 3 and 4 ; the ages are summarized in table 5 and portrayed as age spectra in figures 8 and 9, respectively. The inverse of the ${ }^{39} \mathrm{Ar}{ }^{40} \mathrm{Ar}$ intercept yields an inverse isochron age, whereas the inverse of the ${ }^{36} \mathrm{Ar} /{ }^{40} \mathrm{Ar}$ intercept $\left((40 / 36)_{\mathrm{i}}\right.$ in table 5) indicates the composition of the trapped non-radiogenic argon component (Roddick and others, 1980; Heizler and Harrison, 1988). With the use of IsoPlot (Ludwig, 2000) plateau ages were calculated if $55 \%$ or more of the ${ }^{39} \mathrm{Ar}$ was released in three or more contiguous steps with a probability-of-fit of the weighted mean of more than $5 \%$. All errors are quoted at the $2 \sigma$ level. For analytical details the reader is referred to Appendix A.

Step-heating yielded somewhat irregular age spectra. The first apparent ages are as young as about $395 \mathrm{Ma}$ (IM-2a; Fig. 8) and $385 \mathrm{Ma}$ (IM-5; Fig. 9) and rise to constant values over the following $20-25 \%$ of ${ }^{39} \mathrm{Ar}$ release. Both samples yielded almost concordant plateau ages of $453.2 \pm 1.9 \mathrm{Ma}$ (IM-2a) and $449.4 \pm$ $1.8 \mathrm{Ma}(\mathrm{IM}-5)$ for $79 \%$ and $57.3 \%$ of the released ${ }^{39} \mathrm{Ar}$, respectively. Sample IM-2b yielded a weighted mean age of $453.2 \pm 2.4 \mathrm{Ma}\left(46.6 \%\right.$ of ${ }^{39} \mathrm{Ar}$ release) for the flat upper part of the dome that is concordant to the plateau age of sample split IM-2a (Fig. 8). The decreasing apparent ages for part of the spectrum following the flat part of the dome are probably due to the observed turning of some bigger grains during 
the final part of the experiment, exposing parts that had apparently not homogeneously degassed earlier, given the younger apparent ages of the last four steps. The relatively strong age variation of contiguous steps in IM-5 (Fig. 9) is probably due to the same phenomenon. The plateau ages are within error of the inverse isochronal ages calculated using the plateau steps (table 5). The weighted mean ages of total fusion of single grains are concordant to the plateau and inverse isochronal ages of each sample, but they are a couple of Ma's older than the integrated ages of all heating steps (table 5).

\section{INTERPRETATION AND DISCUSSION}

Although research during the last decade of the past millennium made it clear that phengite in high-pressure metamorphic rocks has often taken up excess argon, the mineral has also commonly yielded meaningful ${ }^{40} \mathrm{Ar} /{ }^{39} \mathrm{Ar}$ ages (Okay and Monié, 1997; Bosse and others, 2000; Gao and Klemd, 2003; Rodriguez and others, 2003). Incorporation of excess argon by phengite has been explained by its partial recrystallization during subsequent metamorphism at lower pressure (Hammerschmidt and Franz, 1992; Hannula and McWilliams, 1995; de Jong and others, 2001), or by strongly restricted fluid mobility during the high-pressure metamorphism (Scaillet, 1996; Boundy and others, 1997; de Jong, 2003). The fluid activity in rocks depends on their pre-metamorphic history (Scaillet, 1996; Okay and Monié, 1997). In our case, the late Precambrian to Cambrian pelagic siliceous sediments that cover the ocean-floor pillow basalts (unit 1) and the Fe- and Mn-rich ocean-floor chert protoliths of the dated phengite-bearing quartzite mylonite (unit 3) were in all probability still relatively water-rich at their arrival at the trench and during early accretion. The occurrence of different generations of progressively stronger deformed quartz veins points to the presence of a fluid phase throughout the deformation history. In addition, the formation of glaucophane at the cost of magmatic minerals in the basaltic rocks may have liberated water, depending on the exact reaction by which it formed. The dated quartzite mylonites were therefore not metamorphosed under fluid-deficient conditions and were not recrystallized at a later stage. Under these metamorphic conditions, the still relatively young, pelagic sediments had, hence, not cumulated significant, if any, radiogenic argon. It is thus highly unlikely that the obtained ages of ca. 450 Ma were affected by excess argon. The concordant step-heating and single grain total fusion ages of the two samples provide additional supportive evidence against the latter phenomenon, because phengite with excess argon may show highly 
different plateau ages for neighboring samples or different grains from a given sample (Ruffet and others, 1995; de Jong and others, 2001).

The amount of older detrital mica in these pelagic sediments was probably negligible, because microstructures indicative of such components, like porphyroclasts and strain shadows are lacking. In addition, straightforwardly recognizable detrital feldspar is absent. Moreover, we can argue on geochemical grounds that it is highly unlikely that the ages of about $450 \mathrm{Ma}$ are due to this phenomenon. In the very first place, the presence of older detrital K-white mica would have resulted in a much greater spread in single grain total fusion ages. Secondly, white mica being a hydrous mineral; it releases Ar during step-heating under vacuum as a consequence of chemical and structural changes within the crystals, rather than by volume diffusion (see references in: de Jong and others, 2001). A major consequence of this is that ${ }^{39} \mathrm{Ar}_{\mathrm{K}}$ and ${ }^{40} \mathrm{Ar} *$ are released simultaneously from cores and rims of crystals, leading to homogenization of ages. In contrast, the presence of different generations of chemically distinct white micas in grain separates often results in complicated or dome-shaped ${ }^{40} \mathrm{Ar} /{ }^{39} \mathrm{Ar}$ age spectra due to their differential degassing over a temperature interval (Wijbrans and McDougall, 1986; de Jong, 2003). In such cases ${ }^{37} \mathrm{Ar}_{\mathrm{Ca}}{ }^{\beta 9} \mathrm{Ar}_{\mathrm{K}}$ ratios proxies for the $\mathrm{Ca} / \mathrm{K}$ ratios of the degassing material - are also irregular. The finding of age plateaux and constant ${ }^{37} \mathrm{Ar}_{\mathrm{Ca}}{ }^{39} \mathrm{Ar}_{\mathrm{K}}$ ratios can thus be taken as an argument in favor of degassing of chemically homogeneous white mica, further underscoring the absence of detrital components. Finally, the phengite ages are comparable to the $460-410 \mathrm{Ma}^{40} \mathrm{Ar} /{ }^{39} \mathrm{Ar}$ ages of glaucophane in high-pressure metamorphic rocks from the Ulan Valley referred to by Chinese authors.

Because the metamorphic temperature of the main tectono-metamorphic recrystallization during which the quartzite mylonites were formed was well below the blocking temperature of K-white mica (see Villa (1998) for a listing), the ca. $450 \mathrm{Ma}$ age is interpreted as the crystallization age of phengite during mylonitization. White mica ages in the accretionary complexes of Japan, represented by the Sambagawa and Mikabu belts, have been interpreted in a similar way (Takasu and Dallmeyer 1990; de Jong and others 2000 and references therein). Our ca. 450 Ma phengite ages are probably a better and in any case a tighter constraint on the age of accretion-related tectono-metamorphic recrystallization than the range of 460-410 $\mathrm{Ma}{ }^{40} \mathrm{Ar} /{ }^{39} \mathrm{Ar}$ ages of glaucophane quoted by Chinese authors. Glaucophane is K-poor and submicroscopic inclusions of K-rich minerals like mica, which may have formed during later recrystallization or alteration, may critically influence its age (Sisson and Onstott, 1986). The meta-gabbro/leucogabbro lens that occurs 
in the quartzite mylonite of unit 3 (fig. 3) has a foliated and lineated margin from which blueschist IM-19 was sampled. The micro-boudinage of magmatic augite in IM-19 occurred in stability field of crossite that was formed at the expense of glaucophane during exhumation. This implies that the final stages of the penetrative ductile deformation during which the dated quartzite mylonites IM-2 and IM-5 were formed also occurred during exhumation. Our ca. 450 Ma phengite dates provide, hence, an age constraint on the final phase of the formation of the Ondor Sum subduction-accretion complex.

Xiao and others (2003) pointed out that the right-way-up ocean plate stratigraphy and the upwardfacing pillows of unit 1 of the Ondor Sum accretion-subduction complex, together with the consistent northward dip of the entire section, indicate that the rocks have not been overturned. Therefore, they envisaged that southward accretion took place on a north-dipping subduction zone that generated the Ulan arc. Our ca. $450 \mathrm{Ma}$ plateau ages would thus constrain the dynamic recrystallization of the quartzite mylonites formed during this phase of southward accretion (fig. 4A). Accordingly, this event was of Late Ordovician age according to the time-scale of Harland and others (1990) or earliest Ashgill using the recent chronostratigraphic scale of Webby and others (2004).

The supra-subduction zone ophiolite sequence and a variety of subduction-related leucocratic rocks in the Tulinkai area that yielded zircons with U-Pb SHRIMP ages of 477 to $457 \mathrm{Ma}$, as indicated above, have highly variable $\varepsilon_{\mathrm{Nd}(\mathrm{t})}(+11.9--0.75)$ and high initial $\mathrm{Sr}$ ratios $\left({ }^{87} \mathrm{Sr}^{86} \mathrm{Sr}_{\mathrm{i}}=0.7043-0.7062\right)(\mathrm{Jian}$ and others, 2006). On the basis of these data the authors favor a near-trench setting for these magmatic rocks and generation by ridge-trench interaction. This interpretation supports our model of an early Paleozoic intra-oceanic evolution of the Ondor Sum subduction-accretion complex and the Ulan arc (fig. 4A). Jian and others (2006) also pointed out that younger ages of ca. $437 \mathrm{Ma}$ for metamorphic zircons from some of these leucocratic rocks may reflect intra-oceanic overthrusting and crustal thickening under amphibolite-facies conditions. A ca. $420 \mathrm{Ma}$ age of an albitite dyke in a serpentinite places an upper time constraint on this event (Jian and others, 2006). These ages strengthen our interpretation that the ca. 450 Ma age of phengite from the Ulan Valley better constrains the timing of the high-pressure metamorphism in the Ondor Sum subduction-accretion complex than the ${ }^{40} \mathrm{Ar} /{ }^{39} \mathrm{Ar}$ ages of glaucophane referred to by Chinese authors. Indeed, the youngest glaucophane age of ca. 426 Ma agrees with the timing of the postaccretion metamorphism and may be related to recrystallization caused by it. 


\section{EARLY PALEOZOIC BELTS AND TERRANES IN CHINA, KAZAKHSTAN, MONGOLIA, RUSSIA, VIETNAM, JAPAN}

Our radiometric dating implies that a 200 Ma gap existed between the early accretion in the Ondor Sum subduction-accretion complex along the northern margin of the North China craton and the formation of the Solonker suture zone, which marks the final closure of the Paleo-Asian Ocean. As shown below, other margins of the North China craton and of many other continental fragments in the Paleo-Asian Ocean were bordered by early Paleozoic subduction-accretion complexes, island arcs or contained calc-alkaline volcanic margins, which were formed well before the final closure of this oceanic basin.

\section{Kazakhstan and Junggar}

A number of early Paleozoic ophiolites occur along the northern margin of the Junggar terrane (Xinjiang, China; fig. 1), namely, the Tangbale-Mayile-Hongguleleng-Aermantai complexes (Wang and others, 2003). Radiometric and micro fossil data show that the Tangbale ophiolite was formed in late CambrianOrdovician time, whereas, the age of the other complexes is less well constrained, but probably pre-middle Ordovician (Wang and others, 2003). The ophiolites are associated with volcanic and volcanoclastic sequences, as well as radiolarian cherts, turbidites and limestones of Ordovician and/or Silurian age (Wang and others, 2003). ${ }^{40} \mathrm{Ar} /{ }^{39} \mathrm{Ar}$ ages of sodic-amphibole from blueschists in the Tangbale ophiolite mélange (table 6) point to accretion and high-pressure metamorphism in middle Ordovician time along the northern margin of Junggar.

The Altai-Sayan fold belt (fig. 1) comprises terranes of different age and derivation that are separated by subduction-accretion complexes that contain ophiolites, and are cut by strike-slip faults of different age (Zonenshain and others, 1990; Berzin and Dobretsov, 1994; Buslov and others, 2001; Windley and others, 2002). The Chara ophiolite belt is located along the northeastern margin of the Kazakhstan composite terrane and was formed in Late Carboniferous-Permian time as a strike-slip zone during the collision with Siberia, but also contains older serpentine mélanges and accreted terranes (Buslov and others, 2001). The oldest subduction-accretion complex is of Early Paleozoic age and contains amongst others: cherts, eclogites, amphibolites and blueschists, which yielded K-white mica with Late Ordovician to Early Silurian K-Ar ages (table 6). 


\section{Mongolia, Russian Far East and northeastern China}

Mongolia and bordering areas in Russia contain a number of crustal blocks situated along the southern margin of Siberia (Badarch and others, 2002; Dobretsov and others, 2003; Khain and others, 2003). A compilation by these authors revealed that these amphibolite- and locally granulite-facies metamorphic rocks yielded many radiometric ages in the 535-450 Ma range. They explained these data by high-grade metamorphism and anatexis related to Cambro-Ordovician ridge subduction and/or terrane collision.

Northeastern China and adjacent areas of the Russian Far East, contain a complex suite of continent-related terranes composed of rocks of in part early and middle Paleozoic age of diverse tectonic settings (Khanchuk and others, 1996; Şengör and Natal'in, 1996; Kojima and others, 2000; Nokleberg and others, 2001, 2004; Jia and others, 2004). A number of these terranes that are situated just north of the North China craton have been grouped as the Khanka superterrane (Kojima and others, 2000; Nokleberg and others, 2001, 2004).

The Khanka superterrane in the southern part of the Russian Far East (fig. 1, loc. 1) comprises four terranes that amalgamated in the Silurian (Kojima and others, 2000) and were covered by similar Devonian and Mississippian continental-rift-related volcanic and sedimentary series (Nokleberg and others, 2001). The superterrane consists of a series of related terranes of early and middle Paleozoic age, representing a continental-margin, an island arc and subduction-accretion complexes (amongst others the Voznesenka terrane) with Cambrian ophiolite, chert, clastic rocks and limestone (Khanchuk and others, 1996; Kojima and others, 2000; Nokleberg and others, 2001). The Sergeevka terrane is located along the southeastern margin of Khanka and comprises a gneissose meta-dioritic complex, granite and associated metamorphic rocks that may have been formed in an island arc (Khanchuk and others, 1996; Kojima and others, 2000; Nokleberg and others, 2001). Rocks from this long-lived and complex terrane yielded isotopic ages in the 490-530 Ma range and the dismembered Sergeevka ophiolite contains metagabbros with 430 to 470 Ma-old hornblendes (table 6) that are as old as hornblendes of some ophiolites in Japan (see below).

Jia and others (2004) argued, on the basis of whole-rock ${ }^{40} \mathrm{Ar} /{ }^{39} \mathrm{Ar}$ plateau ages of blueschists and syn-tectonic granites, that two terranes that are not part of Khanka, namely the Jiamusi and SongliaoZhangguangcai blocks (fig. 1, loc. 2) collided along the Heilongjiang belt (also known as Mudanjiang belt) 
at about 450-410 Ma. This belt is regarded as a subduction-accretion complex and contains, amongst others, serpentinized ultramafic rocks and gabbro, rare plagiogranite, pillow basalt, marble, a variety of siliceous-argillaceous metasediments and blueschists (Yan and others, 1989). The amphibolite- to granulite-facies metamorphic Mashan complex, which forms part of the Jiamusi block, has yielded ca. 500 Ma SHRIMP zircon ages (table 6).

\section{North and South Qinling Belts}

The Qinling belt of eastern central China, developed to the south of the North China craton (fig. 1, loc. 3), is divisible into northern and southern belts that are separated by metamorphic rocks with Late Carboniferous ${ }^{40} \mathrm{Ar} /{ }^{39} \mathrm{Ar}$ hornblende ages (Zhai and others, 1998).

The northernmost part of the North Qinling belt contains sediments accumulated on the southern passive margin of the North China craton formed by latest Mesoproterozoic metamorphic rocks (Zhai and others, 2003). The youngest sediments are mid-Ordovician that were deformed and metamorphosed under greenschist-facies conditions before deposition of mid-Carboniferous strata (Xue and others, 1996a, b). The central Qinling island-arc, farther south, contains deformed, medium pressure/temperature $(P / T)$ metaigneous rocks with 487 to $470 \mathrm{Ma}$ single-zircon ${ }^{207} \mathrm{~Pb} /{ }^{206} \mathrm{~Pb}$ evaporation ages, and relatively undeformed calc-alkaline granitoid plutons with 422 to 383 Ma isotopic ages (Erlangping unit: Ratschbacher and others, 2003 and references therein) that truncate older structures (Xue and others, 1996a, b). 434-404 Ma ${ }^{40} \mathrm{Ar} /{ }^{39} \mathrm{Ar}$ hornblende ages constrain the time of metamorphism related to these intrusions (Sun and others, 2002a) or their cooling (Zhai and others, 1998). The lower Qinling unit developed farther south comprises gneisses (local granulites), amphibolites and marbles, with Paleoproterozoic and Neoproterozoic metamorphic ages, as well as early Paleozoic K-Ar mineral ages (that is $370-480$ Ma see Ratschbacher and others (2003) for a compilation). The northern zone of the unit contains lenses and blocks of eclogite and gneiss that have yielded garnets with inclusions of coesite and zircons with included micro-diamonds. The ultrahigh-pressure metamorphism occurred at around $500 \mathrm{Ma}$ (table 6; Yang and others, 2003).

These data have been interpreted in terms of the formation of an intra-oceanic island arc (Erlangping unit) caused by southward (Xue and others, 1996a, b) or northward (Ratschbacher and others, 2003) subduction of the oceanic basin bordering the North China craton in the early Ordovician. Following 
the closure of the North Qinling back-arc basin (Sun and others, 2002a), the island arc, micro-continents (like the lower Qinling unit) and subduction-accretion complexes collided with the southern margin of North China before the intrusion of latest Silurian to Early Devonian post-collisional calc-alkaline granitoids (Xue and others, 1996a, b; Ratschbacher and others, 2003). Intrusion of these stitching plutons is part of the building of a ca. $400 \mathrm{Ma}$ Andean-type continental margin arc along the amalgamated southern margin of the North China craton due to northward subduction of oceanic lithosphere (Ratschbacher and others, 2003).

In contrast in the South Qinling belt, most of the isotopic dates that refer to the age of the (ultra) high-pressure metamorphism that formed the local coesite- and diamond-bearing eclogites span the late Carboniferous to late Triassic (references in: Gao and others, 1995; Chang, 1996; Zhai and others, 1998; Sun and others, 2002a, b; Roger and others, 2003; Liou and others, 2004). Recently, however, Qiu and Wijbrans (2006) obtained Late Ordovician to Silurian ${ }^{40} \mathrm{Ar}{ }^{\beta 9} \mathrm{Ar}$ ages from eclogites in the Dabieshan by stepwise crushing of garnet (table 6) and they suggest that these ultrahigh-pressure metamorphic rocks were first formed in the early Paleozoic. Also eclogite in the northwest Dabieshan yielded early Paleozoic isotopic ages that were interpreted by Yang and others (2003) as dating the amphibolite-facies recrystallization of the (ultra) high-pressure metamorphic rocks (table 6).

\section{Tianshan Belt}

The ca. $400 \mathrm{~km}$ wide and $2500 \mathrm{~km}$ long Tianshan belt similarly records about $200 \mathrm{Ma}$ of tectonic history of collision of the Tarim craton and intervening smaller crustal fragments with the southern Angaran active margin of the Siberian continent (Shu and others, 2002, 2004; Laurent-Charvet and others, 2002, 2003; Xiao and others, 2004b). A central belt is separated from the northern and southern Tianshan belts by suture zones (Windley and others, 1990) that contain mélanges with a schistose meta-pelitic matrix that surrounds blocks of (ultra) mafic magmatic rocks, tholeiitic pillow lavas, siliceous rocks and limestones of Ordovician to Late Silurian age, as well as blueschists, eclogites and (mafic) granulites (Gao and others, 1998; Shu and others, 2002, 2004; Xiao and others, 2004b).

The Central Tianshan belt (fig. 1, loc. 4) is considered as an Early Ordovician to Early Silurian magmatic arc (table 6) formed on Proterozoic basement and overlain by Late Paleozoic platform sediments 
(Windley and others, 1990; Laurent-Charvet and others, 2002; Shu and others, 2002, 2004; Xiao and others, 2004b). The immature, intra-oceanic Harlik-Dananshu arc, situated in the central Asian archipelago to the north of the central Tianshan arc, was also initiated in the Early Ordovician (Xiao and others, 2004b, and references there-in).

Despite the formation of an Ordovician-Silurian magmatic arc due to subduction of oceanic lithosphere isotopic ages for blueschists and eclogites from the mélanges along the Central Tianshan's northern limit in western China cluster closely around $350 \mathrm{Ma}$ (Gao and others, 1998; Gao and Klemd, 2003). Geochronologic indications for early Paleozoic high-pressure metamorphism in this area and correlative belts farther west in Kyrgyzstan (Atbashy eclogite belt) and in Tajikistan (Fan-Karategin blueschist belt) are not conclusive (Wang and others, 2006). However, the latest Neoproterozoic to earliest Early Cambrian Weiya granulite from the northern margin of the eastern Central Tianshan belt experienced an early Paleozoic retrograde thermo-tectonic event (Shu and others, 2004; table 6).

The Makbal coesite-grade eclogite in the northern Tianshan belt in Kyrgyzstan may have been formed around Cambrian Ordovician boundary times (table 6).

\section{Kunlun Belt}

The Kunlun belt occurs to the south of the Tarim craton and the Qaidam block and is divided into a western and an eastern range that are offset along the sinistral Altyn Tagh strike-slip system (fig. 1). The Kunlun belt contains the remnants of superimposed early Paleozoic and late Paleozoic-Triassic arcs. In both the western and the eastern Kunlun belt the older suite of batholiths shows a pronounced concentration of 450-490 Ma radiometric ages, pointing to the presence of an Early to Late Ordovician magmatic arc (Yuan and others, 2002; Cowgill and others, 2003; Schwab and others, 2004). The youngest isotopic ages obtained by Cowgill and others (2003) on batholiths in both belts are identical (384 \pm 2 and $389 \pm 5 \mathrm{Ma}$, that is Middle Devonian). Ca. 405 Ma-old lamprophyres and a $384 \pm 2$ Ma-old pluton are post-tectonic (Schwab and others, 2004).

Based on data from the Kudi area (fig. 1, loc. 5) Xiao and others (2002) proposed a model of an early Paleozoic arc-accretionary prism for the western Kunlun belt that has resemblance to the model for the early Paleozoic tectonic evolution of the Ondor Sum subduction-accretion complex, outlined earlier in 
this paper. In agreement with Mattern and Schneider (2000), they envisaged that in the Late Cambrian to earliest Ordovician an oceanward-dipping intra-oceanic subduction zone was generated to the south of Tarim. This led to the formation of the earliest Ordovician intra-oceanic Yixieke arc that was emplaced northward onto the margin of Tarim (Xiao and others, 2002). This process gave rise to flip in the subduction polarity, and consequent northward subduction beneath the southern margin of the accreted Yixieke arc led to the formation of an Early to Mid-Ordovician Andean-type continental margin on the southern side of Tarim (Xiao and others, 2005). The end of northward subduction may be related to the docking of the Kudi terrane, a Precambrian continental fragment with gneisses with Late Ordovician to Silurian isotopic ages (table 6) that probably record the collision (Matte and others, 1996; Zhou and others, 1999). Yuan and others (2002) argued that the end of the collision is constrained by the $405 \pm 2$ Ma singlegrain zircon U-Pb age of the post-dynamic, A-type North Kudi pluton and coeval lamprophyre dikes, indicating the beginning of extensional deformation that would last until the Early Permian. Schwab and others (2004) underlined the similarities in Paleozoic tectonic evolution between the Kunlun belt and the Qinling belt, 2500 to $3000 \mathrm{~km}$ farther to the east. They compared the formation and accretion of the intraoceanic Yixieke arc, with that of the Erlangping unit, and the docked Kudi terrane with the Qinling microcontinent.

Liu (ms) obtained 440-360 Ma hornblende and mica ${ }^{40} \mathrm{Ar} /{ }^{39} \mathrm{Ar}$ ages from Proterozoic gneisses from both sides of the central Kunlun fault in the eastern Kunlun range. He interpreted these ages to reflect the age of amphibolite-facies metamorphism during collision of the South and North Kunlun blocks that followed the closure of the small oceanic or marginal basin between them.

\section{North Qilian Belt}

The North Qilian Belt (fig. 1, loc. 6) comprises (1) a northern terrane with middle Cambrian sediments (Wu and others, 1993), (2) a ca. $1000 \mathrm{~km}$ long, discontinuous belt composed mainly of greenschist-facies metamorphic felsic and mafic volcanic rocks interpreted as an Ordovician volcanic (island) arc (Yin and Harrison, 2000; Wang and others, 2005), and (3) a southern terrane accretionsubduction complex with abyssal and bathyal sedimentary rocks, an imbricated ophiolite (Qian and Zhang, 2001), with blueschists, blocks of eclogite, gabbro, and serpentinized and carbonated ultramafic rocks (Liu, 
ms; Wang and others, 2005). Phengite and glaucophane from the southern terrane yielded 460-440 Ma KAr and ${ }^{40} \mathrm{Ar} /{ }^{39} \mathrm{Ar}$ ages (Xiao and others, 1986; Song and Wu, 1992; Wu and others, 1993; Zhang and others, 1997; Liu, ms). Granodiorite and associated skarn formed in Proterozoic continental fragments present in the southern terrane yielded Late Ordovician isotopic ages (table 6). Ordovician to Early Silurian (table 6) rhyolites and basalts (Wang and others, 2005) and intrusive rocks were emplaced in an island-arc setting (Zhang and others, 2006).

Wang and others (2005) interpreted the geochemistry of the volcanic rocks as pointing to an Ordovician volcanic arc formed on the southern margin of the North China craton above a northward subduction zone, possibly evolving into an island arc separated from the continent by a back-arc basin. The northward drifting of the Central Qilian microcontinental fragment, with Archean basement rocks (Liu, $\mathrm{ms}$ ), eventually resulted in the amalgamation of both terranes and their collision with the North China craton in Silurian times (Wang and others, 2005).

\section{North Qaidam-Altun Eclogite Belt}

The North Qaidam-Altun eclogite belt occurs over almost the entire length of the northern margin of the Qaidam block (constituted by Precambrian metamorphic rocks with a Paleozoic sedimentary cover), and is displaced by the Altyn Tagh fault (fig. 1). The belt comprises quartzo-feldspathic and pelitic gneisses with local garnet peridotites and eclogite lenses and layers, which may contain ultrahigh-pressure minerals (Song and others, 2003; Zhang and others, 2004; Liou and others, 2004).

Metamorphic zircon from eclogites and garnet peridotites yielded U-Pb TIMS (Thermal Ionization Mass Spectrometry) and SHRIMP ages that span 436 to $504 \mathrm{Ma}$; eclogites have whole-rock-garnetomphacite Sm-Nd isochrons in the 500-435 Ma range (Zhang and others, 2001; 2004; 2005; Yang and others, 2002; Song and others, 2003), which according to these authors date the (ultra) high-pressure metamorphic conditions. Exhumation to lower-crustal depths is constrained by ${ }^{40} \mathrm{Ar} /{ }^{39} \mathrm{Ar}$ ages of 477 to 407 Ma (Zhang and others, 2005; table 6). I-type granites in the region yielded SHRIMP ages of 496-445 Ma (Yang and others, 2002). The North Qaidam-Altun eclogite belt probably constituted a tectonic collage of multiple (ultra) high-pressure metamorphic units formed as a result of early Paleozoic (that is 500-445 Ma) 
subduction and subsequent collision between the Qilian and Qaidam blocks, which were probably both Precambrian micro-continents (Song and others, 2003; Zhang and others, 2005).

Bian and others (2004) regarded the entire Kunlun-Qilian-Qinling system during the Early Ordovician to latest Silurian as constituted by an number of colliding micro-continents fringed by subduction-accretion complexes and island arcs developed as a result of northward subduction and closure of oceanic basins.

\section{South China and Indochina}

Although the tectonic significance and geodynamic setting are unclear, scarce information implies that the Indochina block (or Annamia) and the southern part of the Cathaysia block (that is, the southern South China craton) were affected by Silurian magmatism, regional sub-greenschist facies metamorphism and deformation. This is indicated by U-Pb zircon ages (table 6) and by a lack of Silurian sediments, a regional angular unconformity between unmetamorphosed Late Devonian and younger deposits and folded Neoproterozoic to early Paleozoic metasediments of the South China craton with isotopic ages of about 440 to $415 \mathrm{Ma}$ (Zhao and Cawood, 1999; Roger and others, 2000, and references therein). The Dai Loc and Kontum massifs in the Indochina craton of central Vietnam (fig. 1, loc. 9) contain early Paleozoic, in part granulite-facies gneisses (Carter and others, 2001; Lan and others, 2003) and granodiorite (Nagy and others, 2001) (table 6).

\section{Japanese Belts}

The Japanese terranes oceanward of the Hida belt (fig. 1, loc. 11), the geotectonic element the closest to the Asian continent and that can be regarded as the eastward continuation of the $\mathrm{CAOB}$, are generally interpreted as subduction-accretion complexes (Isozaki, 1997a, b). Only a small number of terranes have been considered as derived from a mature island arc or a micro-continent (for example, Faure and Charvet, 1987; Aitchison and others, 1991; Maruyama and others, 1997; Hada and others, 2001; Takagi and Arai, 2003), and occur isolated in the Japanese islands due to late Triassic and younger tectonism. These are the Kurosegawa terrane (western Honshu and Kyushu; indicated in fig. 1 as $\mathrm{H}$ and $\mathrm{K}$, respectively), the Hida Gaien (or Marginal) terrane (central Honshu), the South Kitakami terrane (central 
and northeastern Honshu; fig. 1, loc. 10) and parts of the Paleo-Ryoke terrane (in restricted areas from Kyushu to the Kanto Mountains of central Honshu). These four terranes can be correlated on the basis of similarities in litho- and bio-stratigraphy of Late Silurian to early Middle Devonian and Late Palaeozoic sedimentary series, isotopic ages and petrochemistry of late Ordovician and Permian granitoids (Umeda, 1998; Ehiro, 2000; Hada and others, 2000; Takagi and Arai, 2003; Kurihara, 2004; Kawajiri, 2005). The Hida Gaien terrane as used in this paper refers to the recently redefined Hida Gaien belt by Tsukada and others (2004) that crops out along the southern margin of the Hida belt (fig. 1, loc. 11), which it structurally underlies. These authors pointed out that part of the tectonic elements of the classic belt can be regarded as belonging to the Paleozoic Renge, Suo, Akiyoshi and Maizuru subduction-accretion complexes.

The Oeyama suite is interpreted as an early Paleozoic ophiolite nappe that occupies the highest structural position in the stack of superimposed subduction-accretion complexes of southwest Japan (Ishiwatari and Tsujimori, 2003), and is here regarded as belonging to the Renge belt, as defined by Nishimura (1998). A ca. $560 \mathrm{Ma}$ Sm-Nd age of a gabbro dyke with magmatic clinopyroxene, plagioclase and (?) hornblende, and MORB-like affinities, suggests that the Oeyama ophiolite formed during the Cambrian (Hayasaka, 1995, in: Tsujimori and Itaya, 1999). The peridotite of the Oeyama suite may have been formed in a supra-subduction zone mantle beneath an intra-oceanic arc (Tsujimori and Itaya, 1999; Ishiwatari and Tsujimori, 2003). The Osayama serpentinite mélange, which is associated with the Oeyama belt, contains tectonic blocks of kyanite- and staurolite-bearing high-pressure metamorphic gabbros and a rare blueschist with an eclogite-facies mineral assemblage that yielded early Paleozoic isotopic ages (table 6), which match those from the Sergeevka ophiolite of the southern part of the Russian Far East (fig. 1, loc. 1; table 6).

Ishiwatari and Tsujimori (2003) and Sakashima and others (2003) have considered the South Kitakami terrane as an early Paleozoic active continental margin or mature island arc, on the basis of late Cambrian to Ordovician isotopic ages from ophiolite, blueschists, as well as calc-alkaline and granitic rocks (table 6). Metamorphic rocks with hornblendes that have 400-445 Ma K-Ar ages furthermore occur in a serpentinite mélange in the Kurosegawa terrane (Tsujimori and Itaya, 1999; Ishiwatari and Tsujimori, 2003). 


\section{GEODYNAMICS}

Şengör and others (1993) considered all Precambrian crustal blocks present in the CAOB as fragments derived from the margin of the Laurentian part of the former Meso-Neoproterozoic supercontinent Rodinia (that is from Siberia and, probably, North China). These were emplaced as a result of the separation of a single magmatic arc from this margin in latest Neoproterozoic-Early Cambrian time (namely, the Kipchak arc), rather than as micro-continents. In contrast, based on paleomagnetic data that point to predominant migration of such continental fragments from Gondwana toward Siberia, Mossakovsky and others (1994) and Didenko and others (1994) regarded these fragments as Gondwanaderived micro-continents. Other authors like for example, Dobretsov and others (1995) and Buslov and others $(2001,2004)$, however, underlined the heterogeneity of these fragments and inferred that they were composite micro-continents with Gondwanan and "Laurentian" fragments. The evolution of microcontinental fragments can be quite complicated as illustrated by the Altai-Sayan terrane, for which Fortey and Cocks (2003) proposed that it rifted from Siberia around Cambrian-Ordovician boundary times and subsequently drifted to obtain a peri-Gondwanan position in the Caradoc.

In the following section we will point out that micro-continents that currently form part of Asia as a result of latest Paleozoic to earliest Mesozoic collision were at least in part peri-Gondwanan terranes. These terranes were situated close to the northeastern Cimmerian margin of the Gondwana supercontinent in the early Paleozoic, and fringed by subduction zones, accretionary complexes and calc-alkaline volcanic margins, before they separated from this margin after the middle Devonian and subsequently drifted northward. The early Paleozoic tectonic cycle was preceded by, and a consequence of, the break-up of Rodinia. This event is the rationale behind the accumulation of late Neoproterozoic to earliest Paleozoic passive margin sediments of the eastern margin of Gondwana, the North China craton and many of the micro-continents of mainland Asia.

\section{The Early Paleozoic Gondwanan Margin}

Paleogeographical reconstructions by $\mathrm{Li}$ and Powell (2001) imply that during the Early Cambrian, the North and South China cratons (the latter forming part of a continental ribbon with northwest Tasmania in its southern tip) were located adjacent to the Australia-New Zealand-Antarctica continental margin of 
eastern Gondwana, close to or in the Paleo-Pacific oceanic basin. The magmatic and tectonic evolution of the eastern Gondwanan margin is related to different subduction stages of the Paleo-Pacific Ocean and associated marginal basins (Li and Powell, 2001; Veevers, 2004; Foster and others, 2005), as a result of which the Terra Australis Orogen was formed that continued into South America (Cawood, 2005). Oblique subduction was initiated in the East Gondwana segment in late Neoproterozoic time (580-560 Ma; Cawood, 2005), or in the earliest Phanerozoic (ca. 550 Ma; Veevers, 2004). The main pulse of convergence started at about 530-520 Ma (Cawood, 2005) and enduring westward subduction occurred from 490 Ma onward (Veevers, 2004). Ultrahigh-pressure metamorphic conditions were attained during the Ross orogeny in Antarctica that are dated by $\mathrm{Sm}-\mathrm{Nd}$ and ${ }^{238} \mathrm{U}_{-}{ }^{206} \mathrm{~Pb}$ methods at about $500 \mathrm{Ma}$, whereas the amphibolitefacies overprinting is constrained by ${ }^{40} \mathrm{Ar} /{ }^{39} \mathrm{Ar}$ ages of 490-486 Ma for Ca-amphibole (Liou and others, 2004).

Paleomagnetic data suggest that the northwestern Tasmania part of the ribbon continent that also contained South China, may have accreted to the Pacific margin of Gondwana by the Late Cambrian (Li and Powell, 2001). Due to the oblique subduction of Paleo-Pacific oceanic lithosphere below the eastern Gondwanan margin in Early Cambrian time, the South and North China micro-continents traveled along the active margin, reaching their position near the Cimmerian re-entrant by the Early Ordovician (Li and Powell, 2001; fig. 10). The Arabia-Iran-Himalayan-part-of-India segment of this re-entrant may have been an active margin from the terminal Neoproterozoic to at least the Early Cambrian, characterized by magmatic arc complexes and possibly a back-arc zone of attenuated continental crust, developed above a continent-ward dipping subduction zone (Ramezani and Tucker, 2003). Research by many workers has revealed the Himalayan part of the Gondwanan margin experienced widespread early Paleozoic tectonism. Its manifestations in various regions of the Himalayas include Late Cambrian to Early Ordovician largescale thrusting, crustal thickening and ductile deformation; medium- to high-grade regional metamorphism and the generation of granitic crustal melts; uplift and erosion of metamorphic rocks, as well as accumulation of thick sequences of synorogenic sediments (DeCelles and others, 2000; Miller and others, 2001; Gehrels and others, 2003, 2006a, b; Schwab and others, 2004, and references therein). Rolland and others (2002) regarded the Masherbrum Greenstone Complex of the southern Karakoram (NE Pakistan) as a dismembered ophiolite comprising relics of an Early Ordovician subduction-accretion complex, a volcanic arc and a back-arc system formed along the southern margin of a Northern Karakoram micro- 
continent. The Karakoram micro-continent, together with the Helmand block of central Afghanistan and the Lhasa block of Tibet, belonged to the peri-Gondwanan Cimmerian domain during the Early Ordovician (Le Fort and others, 1994). The Cimmerian re-entrant is regarded as composed of a number of semiindependent blocks during the Cambro-Silurian and not as a single entity (Fortey and Cocks, 2003), although for clarity it is depicted as such in figure 10 .

As the oceanic lithosphere that contained North and South China and other micro-continents that now form part of Asia interacted with these active margins rimming East Gondwana, subduction zones and island arcs formed on the rims of different blocks that, in some cases, subsequently may have collided, like for example, the Qilian and Qaidam blocks. Taking into account the age constraints outlined in earlier in this paper, the Ondor Sum subduction-accretion complex probably records this evolution as the entire process of creating the oceanic lithosphere (unit 1), the accretion of oceanic sediments (unit 3), the flip of the subduction polarity and the formation of the Bainaimiao arc in the margin of the North China craton seems to have been accomplished between the earliest Cambrian to the early Silurian. These basalts and ocean floor sediments may hence be relics of the Paleo-Pacific oceanic crust.

As outlined in the previous section, retrograde metamorphism was superimposed on high-pressure assemblages of a number of belts around micro-continents present in the Cimmerian margin of Gondwana and related to the exhumation of subducted rocks and their final cooling. Therefore, orogenic activity may have lasted into the Devonian. The clockwise rotation of the supercontinent in Ordovician to early Devonian time might have attributed to tectonic activity in micro-continents along its margins ( $\mathrm{Li}$ and Powell, 2001).

It is well accepted that by the Early Cambrian (ca. $530 \mathrm{Ma}$ ) Tarim had broken away from the Gondwana supercontinent and formed an independent micro-continent, like North and South China (for example, Meert and others, 2001; Li and Powell, 2001 and references there-in). Nevertheless, because of their close trilobite affinities, the three micro-continents are inferred to have had a position close to Australia until the Late Cambrian (references in: Li and Powell, 2001; Metcalfe, 2002; Choi and others, 2003). Plate reconstructions show that the main continents of Gondwana, Laurentia, Baltica and Siberia were widely separated in the Ordovician (Li and Powell, 2001; Fortey and Cocks, 2003; fig. 10). In the Cambrian to Ordovician the North China and Tarim micro-continents occupied a position close to the Cimmerian margin of Gondwana, thus far from the Siberian craton with which they were to collide in Late 
Paleozoic times (fig. 10). Similarities in pre-Ashgill stratigraphies and fossil record between the North China craton and North Australia confirm this position (Metcalfe, 1996, 1998). Currently available paleomagnetic and fossils records imply that this situation had not essentially changed in the Silurian to latest Early Devonian (Metcalfe, 1996, 1998, 2002; Li and Powell, 2001).

The above paleomagnetic and paleogeographic reconstructions imply that the formation of Late Cambrian to Early Ordovician island arcs, subduction-accretion complexes and high-pressure metamorphic belts in Ondor Sum and the Solonker orogen, the Central Tianshan, some of the Kazakh terranes, the North Qinling, the North Qaidam-Altun belt, the North Qilian Mountains as well as the Kunlun range all formed in a geodynamic setting that was drastically different from that of the Late Paleozoic Central Asian orogenic belt. Silurian granitic magmatism, metamorphism and deformation that affected the southern part of the South China craton implies that this micro-continent probably was part of this orogenic zone along the Cimmerian margin of Gondwana too (fig. 10). Although Carter and others (2001) explained the Late Ordovician to Silurian magmatic event in central Vietnam by an extensional event related to the rifting of Indochina from Gondwana, Nagy and others (2001) pointed out that it cannot be ruled out that the calcalkaline rocks originated in a magmatic arc related to subduction. This would imply that the Indochina micro-continent was located in the orogenic system along the Gondwanan margin as well (fig. 10). Indochina and some of the terranes involved, like the Alashan, Qaidam and Kunlun with their Early Paleozoic stratigraphic, faunal and floral affinities to Tarim, North and South China are widely interpreted as being peri-Gondwanan terranes in pre-middle Devonian times (Metcalfe, 1996, 2002; Fortey and Cocks, 2003).

Middle Paleozoic Rifting and Drifting from the Gondwanan Margin

Paleomagnetic reconstructions by Li and Powell (2001, their figs. 12, 13) show that the North and South China cratons as well as Tarim began to separate from the Cimmerian margin of Gondwana after the Early Devonian, opening the Paleo-Tethyan Ocean, and giving rise to lack of faunal and floral affinities from that time onward (Metcalfe, 1998, 2002). The evolutionary trend of Late Devonian tholeiitic volcanic rocks to Early Carboniferous alkali basalts observed in the Youjiang Basin of the southernmost part of the South China craton, reflects a lithospheric thinning in a passive continental margin related to the opening of the Paleo-Tethys (Guo and others, 2004). Also the present-day northern margin of Tarim records the 
transition from a passive margin to a rifted margin during the same period (Xiao and others, 2004b). After the Early Carboniferous these micro-continents began their northward drift that led to collision with the Angaran active margin of Siberia (fig. 14 of Li and Powell, 2001) by means of subduction of the PaleoPacific (Metcalfe, 1996, 1998; Li and Powell, 2001) or Paleo-Asian Ocean (Xiao and others, 2003; fig. 11). By the end of the Carboniferous the northern sides of the Tarim and North China cratons had evolved into active continental magmatic margins (Xiao and others, 2003, 2004b).

\section{Provenance of Terranes North of the Solonker Suture}

The preceding paragraphs revealed that many micro-continents to the south of the Solonker suture have an East Gondwana provenance. For some of the crustal blocks situated north of this suture a similar case can be made, but for other terranes Gondwana derivation is less clear.

The early Paleozoic Siberian margin.---

The southern part of the Siberian craton changed from a terminal Neoproterozoic to middle Cambrian passive margin to a complex active continental margin (Khain and others, 2003). This margin contains a number of amalgamated cratonic and metamorphic terranes, around which Late Cambrian to middle Ordovician subduction-accretion complexes and late Neoproterozoic and younger island arcs accreted and ophiolite complexes obducted, before the assemblage collided with Siberia (Badarch and others, 2002; Windley and others, 2002; Dobretsov and others, 2003; Khain and others, 2003; Xiao and others, 2004a). Buslov and others (2001), Dobretsov (2003), Dobretsov and others (2003) and Kheraskova and others (2003) proposed that in the 550 to 490 Ma period oceanic islands and Gondwana-derived microcontinents (like for instance, Kokchetav, Tuva-Mongolia, Central Mongolia) collided with a Cambrian to Early Ordovician island arc system present to the south of the Siberian continent, as a result of which many (ultra) high-pressure rocks formed. In Early Ordovician time this system collided with the Siberian continent, leading to attenuation of the island arc volcanism (Buslov and others, 2001; Kheraskova and others, 2003). Subsequently, the southern active margin of Siberia moved progressively southward and in the Ordovician a two km-thick series of calc-alkaline volcanic and volcaniclastic rocks was laid down (Hsü and others, 1991). 
Kazakhstan.---

Kazakhstan is regarded as a composite terrane made up of a number of continental fragments, terranes, island arcs and oceanic crust remnants of different age, and that formed as the result of prolonged accretion and collision (Dobretsov, 2003; Fortey and Cocks, 2003; Khain and others, 2003; Kheraskova and others, 2003; Buslov and others, 2004). Amalgamation of the Kazakh terranes appears to have been accomplished at least by Early Carboniferous time (fig. 11; Li and Powell, 2001; Dobretsov, 2003; Fortey and Cocks, 2003; Torsvik and Cocks, 2004), but continental assemblies as old as Early Devonian (Buslov and others, 2004) or Late Ordovician (Filippova and others, 2001; Kheraskova and others, 2003) have been envisaged too. The collision of Kazakhstan with Siberia took place in the middle Carboniferous (Dobretsov, 2003); Gondwana-derived Tarim appears to have collided with Kazakhstan by mid-Permian time (Şengör and Natalin, 1996).

In southern Kazakhstan several micro-continental fragments with Precambrian granitic gneisses have been identified (Abdulin and others, 1995) that are considered as derived by Neoproterozoic rifting from the margins of Siberia (Berzin and Dobretsov, 1994) or East Gondwana (Mossakovsky and others, 1994; Kheraskova and others, 2003). The latter view is based on similarities in the late Neoproterozoic and early Paleozoic stable margin sequences between Kazakhstan and Australia, China and Tarim (Eganov and Sovetov, 1979). On the basis of faunal considerations Fortey and Cocks (2003) considered a number of the Kazakh terranes (like Chingiz and Chu-Ili) as peri-Gondwanan, which like Tarim, would have drifted across the paleoequator into the northern hemisphere by Ordovician-Silurian boundary times. Also paleomagnetic data indicate that elements of the Kazakhstan composite terrane have consistently drifted northward from at least the Early Ordovician through the Permian (Bazhenov, 2003; Collins and others, 2003; Buslov and others, 2004).

Mongolia, Russian Far East and northeastern China.---

Badarch and others (2002) showed that only the Hutag Uul terrane and its western correlative the Tsagaan Uul terrane of southernmost Mongolia contain Silurian-Devonian strata that lack fossils of Siberian affinity, in contrast to other Mongolian terranes with Precambrian basement. The Hutag Uul terrane is equivalent to the Baolidao arc-accretion complex (fig. 2; Xiao and others, 2003). 
Wilde and others (2000) speculated that the ca. 500 Ma-old metamorphism in the Jiamusi block in northeastern China (fig. 1, loc. 2) occurred while the rocks were located at the margin of Gondwana. However, in the absence of paleomagnetic and paleontological data, the origin of these high-grade metamorphic blocks and the geodynamic setting in which their metamorphism took place, hence, remain unclear. It is therefore not excluded that the Cambro-Ordovician metamorphism of some terranes north of the Solonker suture zone might well have been generated in subduction-arc-accretion complexes fringing Siberia's southern margin, and or during the subsequent collision of the system with this continent, as outlined in an earlier section.

Khanchuk and others (1996) regarded the Voznesenka terrane of the southern part of the Khanka superterrane in the Russian Far East (fig. 1, loc. 1) as element of the early Paleozoic continental margin of Gondwana, on the basis of affinities of Cambrian microfossils with the Australian paleobiogeographic province. These authors also regarded the Sergeevka terrane as Gondwana-derived. Khanchuk and others (1996) envisaged that the Khanka superterrane was rifted from Gondwana in Devonian time, resulting in the formation of bimodal volcanic rocks. In contrast, Şengör and Natal'in (1996) considered the Khanka as part of the northern margin of the North China craton, which we regard as peri-Gondwanan (fig. 10). The amalgamation of the different terranes of Khanka occurred during the early Paleozoic before the deposition of Middle and Late Devonian and younger volcanic rocks and clastic sediments that overlap the entire superterrane (Nokleberg and others, 2004). This would imply that the entire early Paleozoic accretion evolution of the Khanka superterrane took place in a peri-Gondwanan setting. Collision with the North China craton probably occurred in the Early Triassic (Zonenshain and others, 1990; Wu and others, 2004).

\section{Terranes in Japan}

The South Kitakami terrane of northeastern Japan (fig. 1, loc. 10) can be regarded as a Gondwanaderived terrane that documents the entire Paleozoic geodynamic evolution. It comprises a nearly complete and coherent Silurian to Early Cretaceous sedimentary succession that rests on the Miyamori ophiolite and possibly on minor granitic and metamorphic basement of Ordovician age (Tazawa, 2002; Ishiwatari and Tsujimori, 2003; Sakashima and others, 2003; Yoshida and Machiyama, 2004). The Paleozoic strata contain abundant fossil fauna and flora, which document that South Kitakami was part of Gondwana in the Silurian and Devonian, then broke away from this supercontinent and subsequently drifted northward (for 
instance, Ehiro, 2000, and references in Tazawa, 2002. On the basis of middle Permian Boreal-Tethyan mixed brachiopod fauna Tazawa $(1999,2002)$ positioned South Kitakami in the northern hemisphere associated with the North China micro-continent. Using ammonoids, Ehiro and others (2005), however, favored an equatorial position for the terrane during this time slice, closer to the South China microcontinent. South Kitakami has been considered as having formed part of a single system in the early Paleozoic with geologic entities of the Russian Far East: the Khanka superterrane (Şengör and Natal'in, 1996; Tazawa, 2002) or more specifically the Sergeevka terrane (Kojima and others, 2000). The similar Ordovician radiometric ages of some granitoids, the Sergeevka, Miyamori and Oeyama ophiolites, as well as the Matsugadaira-Motai blueschists (table 6) lend some support to this correlation. A Gondwana derivation has also been advocated for the Kurosegawa terrane (Aitchison and others, 1991; Maruyama and others, 1997; Hada and others, 2001).

South Kitakami's clastic series of Permian age contain substantial input from andesitic and granitic sources, and their contact metamorphic aureoles (Takeuchi, 1994), which point to the proximity of island arcs or an active magmatic margin (Yoshida and Machiyama, 2004). Diorite pebbles in middle Permian (Usuginu-type) conglomerates yielded hornblende with 240-270 Ma K-Ar ages (references in: Takeuchi, 1994) and tonalite pebbles contain zircon and monazite with 240-260 Ma CHIME ages (Takeuchi and Suzuki, 2000). Similar conglomerates of Permian age with similarly aged granitic clasts are known from the Kurosegawa terrane (Hada and others, 2000; Takagi and Arai, 2003). The latter authors argued that the source area was formed by the Paleo-Ryoke terrane that contains a number of suites of Permian granitic rocks that yielded hornblende with K-Ar ages in the 250-277 Ma range, and that were generated in an immature volcanic arc or active continental margin. A granodiorite body that probably belongs to the Usukigawa suite in eastern Kyushu yielded zircon with a SHRIMP U-Pb age of $292 \pm 12 \mathrm{Ma}$ (Sakashima and others, 2003). The Hida Gaien terrane experienced widespread deposition of mainly felsic pyroclastic rocks during the Late Carboniferous and Early Permian in a volcanic arc, and local bimodal volcanism in Early Permian time (Takeuchi and others, 2004). Kawajiri (2005) pointed out that the diversity of magma types suggests that the terrane was situated in an island arc or back-arc basin setting in latest Permian time.

Permian gabbro intrusions, local tonalite and plagiogranite, as well as basalt, andesite and rhyolite of Permian to early Triassic age (Jia and others, 2004), occur in northeastern China and the Russian Far 33 
East (Nokleberg and others, 2001, 2004). These rocks form the Laoelin-Grodekovsk terrane that the latter authors interpret as a magmatic arc. Younger, collision-related, Late Permian granitic plutons intrude the terrane and are co-magmatic with Permian volcanic rocks in the Khanka superterrane. Nokleberg and others (2004) suggests that this relation shows that the Laoelin-Grodekovsk magmatic arc accreted to the Khanka superterrane at the end of the Paleozoic. The occurrence of such terminal Paleozoic magmatic and volcanic activity, the presence of a Late Permian-Early Triassic subduction-accretion complex in the Jilin area of northeastern China (Li, 2006) and the Chongjin subduction-accretion complex in northernmost North Korea, which contains late Paleozoic ophiolites, chert and limestone (Nokleberg and others, 2001), all imply that the Solonker suture zone continues eastward to the Sea of Japan (fig. 1).

Principally on geochemical grounds Arakawa and others (2000) and Jahn and others (2000) regarded the Hida belt in Japan as an eastward continuation of the CAOB, rather than as the eastern margin of the North China craton with which it has chemical and geochronological dissimilarities. They arrived at this conclusion on the basis of the age and isotopic characteristics of the Paleozoic to Mesozoic granitic rocks, the young Sm-Nd (Dm) model ages for metapelitic Hida gneisses, implying a sedimentary protolith not older than Early Paleozoic, and finally the 250-220 Ma age for the main metamorphism. Indeed, the range of radiometric ages from the Hida belt is comparable to ca. $240 \mathrm{Ma} \mathrm{U}-\mathrm{Pb}$ zircon ages (F.- $\mathrm{Y}$. Wu, unpublished data in: $\mathrm{Wu}$ and others, 2004), ca. $225 \mathrm{Ma}{ }^{40} \mathrm{Ar} /{ }^{39} \mathrm{Ar}$ biotite and muscovite ages from amphibolite-facies rocks and synorogenic granites from the Hulan group (Xi and others, 2003) located in the easternmost part of the CAOB in China. These early Mesozoic isotopic dates agree with the progressively younger age of suturing signaled in the Introduction of this paper.

The picture that emerges is that the Japanese islands contain remnants of a Gondwana-derived terrane, comprising parts of the present-day South Kitakami, Hida Gaien, Paleo-Ryoke and Kurosegawa terranes made up of early and late Paleozoic sedimentary and volcanic series, as well as late Ordovician and Permian granitoids. As a result of subduction of oceanic lithosphere below this proto-Japan superterrane, early and late Paleozoic high-pressure metamorphic rocks and several subduction-accretion complexes of Permian age were formed. The subduction-accretion complexes contain fragments of ocean floor possibly as old as Cambrian (Oeyama ophiolite, Renge belt) and Late Devonian (early Famenian red chert lenses in basalt of the Hayachine belt in the northern margin of South Kitakami terrane (Hamano and others, 2002)). This points to prolonged subduction-accretion tectonism before the proto-Japan superterrane 34 
collided with the East Asian active margin, formed by the eastern continuation of the CAOB. The timing of this collision is ill constrained but occurred before the intrusion of the 170-200 Ma-old Funatsu granites in the Hida belt, which can be correlated with similar middle Jurassic Daebo-type granitoid intrusions in Korea (Nakajima, 1997). The 250-220 Ma-old main metamorphism in the Hida belt (Arakawa and others, 2000) may be related to the collision. Takeuchi (1994) noted a fundamental change in the source areas of sedimentary basins of South Kitakami and other terranes in Triassic-Jurassic boundary time. He regarded detritus in Jurassic sandstones as derived from medium- to high-grade metamorphic rocks. Such type of metamorphic rocks are only widespread in the Hida belt, suggesting deep erosion of the collision belt between the proto-Japan superterrane and the East Asian margin in early Jurassic time.

\section{Implications}

As outlined above, we view the evolution of suture zones and orogenic belts between the blocks that make up present-day China and surrounding areas in a two-stage tectonic scenario: 1 . The early Paleozoic evolution occurred near the margin of East Gondwana, 2. The late Paleozoic geodynamic development and crustal evolution occurred within a framework for the accretionary building of the Eurasian continent. This explains the 200 million year time-span between the early accretion in the Ondor Sum subduction-accretion complex and the Late Permian age of the Solonker suture zone.

Our two-stage model implies that a vast orogenic system existed along the Cimmerian margin of Gondwana, comprising an archipelago of sometimes colliding micro-continental fragments that were bordered by subduction-accretion complexes, island arcs or contained calc-alkaline volcanic margins. Part of these micro-continents may have been derived by rifting from the Australian part of the Gondwanan margin (for example, South China, Tarim, a number of Kazakh terranes, and Indochina), whereas others may have had a Siberian provenance before their peri-Gondwanan history (like North China; Li and Powell, 2001). This view implies that the early Paleozoic ultrahigh-pressure metamorphism that characterizes the early evolution of many of the Asian micro-continents occurred in a peri-Gondwana orogenic system. It is unclear in how far the early Paleozoic tectono-metamorphic evolution of the periGondwanan terranes is actually related to accretion to the Cimmerian margin. Accretion might have occurred following closure of a marginal basin that could have been created by the same extensional event that could have rafted continental fragments from the Gondwana margin. Cawood (2005) invoked such a 
model for the early Paleozoic tectonic evolution of the Andean segment of the West Gondwanan margin.

The tectonic evolution of the CAOB has certain parallels with those of the Variscan belt in Europe and the Appalachians in the eastern USA, which both contain much older micro-continental fragments that are derived from the margin of West Gondwana (Ziegler, 1989; Pickering and Smith, 1995), like for example, Armorica and Avalonia (figs. 10 and 11). These terranes experienced an important late Neoproterozoic to Early Cambrian crust-forming phase, may contain relics of volcanic island arcs and subduction-accretion complexes, experienced an Ordovician orogenic event prior to collision, and were separated from Gondwana at different times (Schaltegger and others, 2003; von Raumer and others, 2003; Murphy and others, 2004).

A two-stage tectonic scenario in which the tectonic evolution related to accretionary building of Eurasia in latest Paleozoic to earliest Mesozoic time is preceded by earlier tectonic phases not directly related to this event can similarly explain ambiguities in the timing of the collision of the South and North China cratons. A number of authors (like for example, Gao and others, 1995; Chang, 1996; Yang and others, 2003; Liou and others, 2004; review by Roger and others, 2003) assumed that early Paleozoic tectono-metamorphic and magmatic events in the North Qinling belt might be due to episodic collision or collision phases between the North and South China cratons. However, Sun and others (2002a) pointed out that because the Late Silurian to Early Devonian metamorphism and magmatism have been recorded exclusively in the North Qinling belt and are absent in the South Qinling belt, it is not related to the collision between both cratons. Collision between the North and South China cratons in the (early) Permian, or even late Carboniferous, and that climaxed in the Late Triassic, associated with local ultrahighpressure metamorphism in the South Qinling belt (for example, Zhai and others, 1998; Li and Powell, 2001; Sun and others, 2002a, b; Roger and others, 2003; Liou and others, 2004), preceded by early Paleozoic accretion against these micro-continents in a peri-Gondwanan setting, seems to explain most of the available data.

\section{CONCLUSIONS}

${ }^{40} \mathrm{Ar}{ }^{39} \mathrm{Ar}$ dating of phengite has shown that dynamic recrystallization of quartzitic mylonite and ductile deformation in the higher part of the Ondor Sum subduction-accretion complex along the northern 
margin of the North China craton occurred at about 450 Ma. That was about $200 \mathrm{Ma}$ before the final closure of the Paleo-Asian Ocean and the formation of the Solonker suture zone. In all likelihood the oceanic sediments were free of older detrital mica, and unconsolidated and hydrated when they arrived at the trench and they were accreted and metamorphosed under fluid-sufficient conditions. Consequently, we argue that the 200 million year age difference was neither due to the incorporation of excess argon, which often plagues dating of this high-pressure mica, nor to the presence of older detrital mica. Instead, we propose that the Ondor Sum complex formed part of an early Paleozoic orogenic system that involved a number of drifting micro-continents fringed by subduction-accretion complexes and island arcs along the northeastern Cimmerian margin of Gondwana. This might have been preceded by an earlier evolution in the Paleo-Pacific Ocean. Northward drift of the detached North China craton and closure of the PaleoAsian Ocean by double subduction finally resulted in collision of the micro-continent with the southern part of the Central Asian Orogenic belt and Siberia, and the formation of the Solonker suture zone by the endPermian. This type of two-stage scenario probably also applies to the geodynamic evolution of other microcontinents that currently form part of Asia due to collision in the late Paleozoic to early Mesozoic (South China, Tarim, a number of Kazakh terranes, Alashan, Qaidam, South and North Kunlun, Khanka, South Kitakami, and probably Indochina), and which were bordered by early Paleozoic subduction-accretion complexes, island arcs or contained calc-alkaline volcanic margins while located in the Cimmerian margin of East Gondwana. It might be possible that these events in some blocks have been preceded by an earlier evolution in Cambrian time associated with the subduction of the Paleo-Pacific Ocean below the AustraliaNew Zealand-Antarctica continental margin of the Gondwana supercontinent. Finally, this two-stage model implies that an archipelago of micro-continents existed along the Cimmerian margin of Gondwana and that the early Paleozoic ultrahigh-pressure metamorphism that characterizes the early evolution of many of the Asian micro-continents occurred in this vast, peri-Gondwanan orogenic system.

\section{ACKNOWLEDGMENTS}

The analytical work was completed while the senior author $(\mathrm{KdJ})$ was a visiting scientist at the Taiwan

National University financially supported by the National Science Council of Taiwan by means of grant NCS92-2811-M-0022-016- to KdJ, which also helped to defray travel expenses incurred during the project. 
Sun-Lin Chung is thanked for help in various ways during the senior author's stay in Taipei. Discussions with Chikao Kurimoto and Katsumi Kimura during several trips of the senior author to the Geological Survey of Japan in Tsukuba (enabled by grants of the Science and Technology Agency of Japan and the European Union) greatly improved his knowledge of the geology of the Japanese islands. He also gratefully acknowledges the invitation by prof. Hideo Takagi (Waseda univerity, Tokyo) to join an excursion to the Kanto Mountains, enabling to fathom the intricacies of the Paleo-Ryoke nappe. Michel Faure (Orléans university), Bor-ming Jahn (Academia Sinica Taipei), Tatsuki Tsujimori (Stanford university), Bo Wang and Liangshu Shu (Nanjing university) are thanked for discussions and/or kindly supplying pre-prints of papers. BFW thanks Shigenori Maruyama (Tokyo Institute of Technology) for funding of the 2001 fieldwork during which the samples were taken and for the microprobe facilities, for which Dr. S. Takeuchi gave technical support. Mr. S. Okamoto is thanked for his advice on petrography. We acknowledge general funding by grants from the Major State Basic Research Program of China (2001CB409801) and Innovative Projects of the Chinese Academy of Science (KZCX2-SW-119, KZCX1-07, and KZCX2-104). Last but not least, we are grateful for the constructive comments of Bradley Ritts and an anonymous referee. This paper is a contribution to IGCP Project 473. 
APPENDIX A

EXPERIMENTAL PROCEDURES

$$
{ }^{40} \mathrm{Ar} /{ }^{39} \text { Ar Dating }
$$

Phengite separates were prepared from the $64-100 \mu \mathrm{m}$ sieve fraction by means of handpicking under a binocular zoom microscope and subsequent ultrasonic cleaning in demineralized water for five minutes. The mineral separates were wrapped in high-purity aluminum foil and irradiated for 30 hours along with irradiation standard biotite LP-6 (Odin and others, 1982) in the VT-C position of the Tsing-Hua University Open-Pool Reactor, Taiwan. A weighted mean of five fusions of irradiation standard LP-6 Biotite with a calibrated ${ }^{40} \mathrm{Ar} /{ }^{39} \mathrm{Ar}$ age of $128.4 \pm 0.2 \mathrm{Ma}$, based on Fish Canyon Sanidine $(28.02 \pm 0.28$ Ma) (Baksi and others, 1996; Renne and others, 1998) resulted in an average J value of $0.003440063 \pm$ 0.000020617, which is used in the age calculations. The neutron flux gradient across the top and bottom of the irradiation canister was about $3.6 \%$, as indicated by the variation of $\mathrm{J}$ values from the flux monitor.

Irradiated phengite grains were loaded into a high-vacuum sample housing fitted with a sapphire UHV window, and were incrementally heated to fusion with a defocused, continuous ultraviolet (266 nm) laser beam. Experiments were monitored with a coupled Nikon SMZU microscope equipped with a CCD camera and a US laser up collimator/objective lens. The laser probe comprises a US laser 403TQ A.O. quadrupled Nd:YAG laser, an all-metal extraction line and a high resolution VG3600 noble-gas mass spectrometer, operated in static mode, and outfitted with a Nier-type 'Bright' ion source and a Johnston electron multiplier. Chemically active gases were removed with $\mathrm{Zr}-\mathrm{Al}$ and $\mathrm{Fe}-\mathrm{V}$ alloy getters operated at $400^{\circ} \mathrm{C}$. Each heating step lasted for 3 minutes followed by 1 minute of gettering. Extraction line blanks were measured at the start and finish of an experiment and repeated typically every third to fifth step.

Apparent ${ }^{40} \mathrm{Ar} /{ }^{39} \mathrm{Ar}$ ages of individual steps were calculated from the corrected isotopic ratios using decay constants and isotopic abundance ratios given by Steiger and Jäger (1977), and were corrected for blanks, isotopic decay and interference by irradiation-induced contaminant Ar-isotopes derived from $\mathrm{Ca}, \mathrm{K}$ and $\mathrm{Cl}$. The $\left({ }^{36} \mathrm{Ar}{ }^{37} \mathrm{Ar}\right)_{\mathrm{Ca}},\left({ }^{39} \mathrm{Ar} /{ }^{37} \mathrm{Ar}\right)_{\mathrm{Ca}},\left({ }^{40} \mathrm{Ar} /{ }^{39} \mathrm{Ar}\right)_{\mathrm{K}}$ and $\left({ }^{38} \mathrm{Ar}_{\mathrm{Cl}}{ }^{\beta 9} \mathrm{Ar}_{\mathrm{K}}\right)$ ratios used in the corrections for irradiation-induced contaminant Ar-isotopes derived from $\mathrm{Ca}, \mathrm{K}$ and $\mathrm{Cl}$ (determined from irradiated 
aliquots of $\mathrm{K}_{2} \mathrm{SO}_{4}, \mathrm{CaSO}_{4}$ and $\left.\mathrm{KCl}\right)$ are: $2.3992( \pm 1.0487) \times 10^{-4}, 5.6997( \pm 0.1649) \times 10^{-4}, 2.9393( \pm$ $0.2463) \times 10^{-2}$ and $0.5183( \pm 0.0530)$ respectively, with errors quoted on the $1 \sigma$ level. Integrated dates were obtained from the sum total of the peak heights and their errors from the square root of the sum square of the peak-height errors for all steps. Regression lines in ${ }^{36} \mathrm{Ar} /{ }^{40} \mathrm{Ar}$ versus ${ }^{39} \mathrm{Ar} /{ }^{40} \mathrm{Ar}$ correlation diagrams were obtained by cubic least-squares fitting according to York's 1969 procedure. Decay constant and isotopic abundance ratios used: ${ }^{40} \mathrm{~K}_{\text {tot }}=5.543 \times 10^{-10} \mathrm{a}^{-1} ;{ }^{40} \mathrm{~K} / \mathrm{K}=0.01167$ atom \% (Steiger and Jäger, 1977). A ${ }^{40} \mathrm{Ar} /{ }^{36} \mathrm{Ar}$ of $292.4 \pm 0.5$ was measured on aliquots of air Ar. For further details on data correction and age calculations the reader is referred to Lo and Lee (1994). 


\section{REFERENCES}

Abdulin, A. A., Avdeev, A. V., and Seitov, N. S., 1995, On the study of microcontinents and ophiolite zones in Kazakhstan: Occasional Publications, ESRI, New Series 12B, Earth Science and Resources Institute, University of South Carolina, Columbia, South Carolina, p. 97-112.

Aitchison, J. C., Hada, S., and Yoshikura, S. -i., 1991, Kurosegawa terrane: disrupted remnants of a low latitude Paleozoic terrane accreted to SW Japan: Journal of Southeast Asian Earth Sciences, v. 6, p. $83-92$.

Arakawa, Y., Saito, Y., and Amakawa, H., 2000, Crustal development of the Hida belt, Japan: Evidence from $\mathrm{Nd}-\mathrm{Sr}$ isotopic and chemical characteristics of igneous and metamorphic rocks: Tectonophysics, v. 328, p. 183-204.

Badarch, G., Cunningham, W. D., and Windley B. F., 2002, A new terrane subdivision for Mongolia: implications for the Phanerozoic crustal growth of Central Asia: Journal of Asian Earth Sciences, v. 21, p. $87-110$.

Bai, D. H., Zhang, L., and Kong, X. R., 1993a, A magnetotelluric study of the Palaeozoic collision zone in the east of Inner Mongolia, I: Observations and data analysis: Acta Geophysica Sinica, 36, p. 326336.

Bai, D. H., Zhang, L., and Kong, X. R., 1993b, A magnetotelluric study of the Palaeozoic collision zone in the east of Inner Mongolia, II: Two-dimensional modelling: Acta Geophysica Sinica, 36, p. 773-783.

Baksi, A. K., Archibald, D. A., and Farrar, E., 1996, Intercalibration of ${ }^{40} \mathrm{Ar} /{ }^{39} \mathrm{Ar}$ dating standards: Chemical Geology, v. 129, p. 307-324. 
Bazhenov, M. L., Collins, A. Q., Degtyarev, K. E., Levashova, N. M., Mikolaichuk, A. V., Pavlov, V. E., and Van der Voo, R., 2003, Paleozoic northward drift of the North Tien Shan (Central Asia) as revealed by Ordovician and Carboniferous paleomagnetism: Tectonophysics, v. 366, p. 113-141.

Berzin, N. A., and Dobretsov, N. L., 1994, Geodynamic evolution of Southern Siberia in Late Precambrian - Early Paleozoic time, in Coleman, R. G., editor, Proceedings of the $29^{\text {th }}$ International Geological Congress, Part B, Reconstruction of the Paleo-Asian Ocean: Leiden, VSP International Science Publishers, p. 53-70.

BGMRIM (Bureau of Geology and Mineral Resources of Inner Mongolia), 1991, Regional Geology of Inner Mongolia Autonomous Region: Geological Memoirs, Series 2, no. 25, Beijing, Geological Publishing House, 725 p. (in Chinese with English summary).

Bian, Q. -T., Li, D. -H., Pospelov, I., Yin, L. -M., Li, H. -S., Zhao, D. -S., Chang, C. -F., Luo, X. -Q., Gao, S. -L., Astrakhantsev, O., and Chamov, N., 2004, Age, geochemistry and tectonic setting of Buqingshan ophiolites, North Qinghai-Tibet Plateau, China: Journal of Asian Earth Sciences, v. 23, p. $577-596$.

Bosse, V., Féraud, G., Ruffet, G., Ballèvre, M., Peucat, J. -J., and de Jong, K., 2000, Timing of burial and exhumation of eclogite-facies rocks from the Champtoceaux Complex (Variscan belt, France): Geological Journal, v. 35, p. 297-325.

Boundy, T. M., Hall, C. M., Li, G., Essene, E. J., and Halliday, A. N., 1997, Fine-scale isotopic heterogeneities and fluids in the deep crust: $\mathrm{a}^{40} \mathrm{Ar} /{ }^{39} \mathrm{Ar}$ laser ablation and TEM study of muscovites from a granulite-eclogite transition zone: Earth and Planetary Science Letters, v. 148, p. 223-242.

Brown, E. H., 1977, The crossite content of Na-amphibole as a guide to pressure of metamorphism: Journal of Petrology, v. 18, p. 53-72.

Buchan, C., Pfänder, J., Kröner, A., Brewer, T. S., Tomurtogood, O., Tomurhuud, D., Cunningham, D., and Windley, B. F., 2002, Timing of accretion and collisional deformation in the Central Asian Orogenic 
Belt: implications of granite geochronology in the Bayankhongor Ophiolite Zone: Chemical Geology, v. 192, p. 23-45.

Buslov, M. M., Fujiwara, Y., Iwata, K., and Semakov N. N., 2004, Late Paleozoic-Early Mesozoic geodynamics of Central Asia: Gondwana Research, v. 7, p. 791-808.

Buslov, M. M., Saphonova, I., Yu., Watanabe, T., Obut, O. T., Fujiwara, Y., Iwata, K., Semakov N. N., Sugai, Y., Smirnova, L. V., and Kazansky, A. Yu., 2001, Evolution of the Paleo-Asian Ocean (AltaiSayan region, Central Asia) and collision of possible Gondwana-derived terranes with the southern marginal part of the Siberian continent: The Geoscience Journal, v. 5, p. 203-224.

Carter, A., Roques, D., Bristow, C., and Kinny, P., 2001. Understanding Mesozoic accretion in Southeast Asia: significance of Triassic thermotectonism (Indosinian orogeny) in Vietnam: Geology, v. 29, p. 211-214.

Cawood, P. A., 2005, Terra Australis Orogen: Rodinia breakup and development of the Pacific and Iapetus margins of Gondwana during the Neoproterozoic and Paleozoic: Earth-Science Reviews, v. 69, p. 249-279.

Chang, E. Z., 1996, Collision orogen between north and south China and its extension in the Korean Peninsula: Journal of South East Asian Earth Sciences, v. 13, p. 267-277.

Chao, E. C. T., Back, J. M., Minkin, J. A., Tatsumoto, M., Wang, J. W., Conrad, J. E., McKee, E. H., Hou, Z. L. Meng, Q. R., Huang, S. G., 1997, Sedimentary carbonate-hosted giant Bayan Obo REE-Fe-Nb ore deposit of Inner Mongolia, China; a cornerstone example for giant polymetallic ore deposits of hydrothermal origin: United States Geological Survey Bulletin, v. 2143 (http://pubs.usgs.gov/bul/b2143/).

Chen, B., Jahn, B-M., Wilde, S., and Xu, B., 2000, Two contrasting Palaeozoic magmatic belts in northern Inner Mongolia, China: petrogenesis and tectonic implications: Tectonophysics, v. 328, p. 157-182. 
Choi, D. K., Kim, D. H., Sohn, J. W., and Lee, S. -B., 2003, Trilobite faunal successions across the Cambrian-Ordovician boundary intervals in Korea and their correlation with China and Australia: Journal of Asian Earth Sciences, v. 21, p. 781-793.

Chung, S. L., Lee, T. Y., Lo, C. H., Wang, P. L., Chen, C. Y., Yem, N. T., Hoa, T. T., and Wu, G. Y., 1997, Intraplate extension prior to continental extrusion along the Ailao Shan Red River shear zone: Geology, v. 25, p. 311-314.

Coleman, R. G., 1994, Proceedings of the $29^{\text {th }}$ International Geological Congress, Part B, Reconstruction of the Paleo-Asian Ocean: Leiden, VSP International Science Publishers, 177 p.

Collins, A. Q., Degtyarev, K. E., Levashova, N. M., Bazhenov, M. L., and Van der Voo, R., 2003, Early Paleozoic paleomagnetism of East Kazakhstan: Implications for paleolatitudinal drift of tectonic elements within the Ural-Mongol Belt: Tectonophysics, v. 377, p. 229-247.

Cope, T., Ritts, B. D., Darby, B. J., Fildani, A., and Graham, S. A., 2005, Late Paleozoic sedimentation on the Northern margin of the North China Block: Implications for regional tectonics and climate change: International Geology Review, v. 47, p. 270-296.

Cowgill, E., Yin, A., Harrison, T. M., and Xiao-Feng, W., 2003, Reconstruction of the Altyn Tagh fault based on $\mathrm{U}-\mathrm{Pb}$ geochronology: Role of back thrusts, mantle sutures, and heterogeneous crustal strength in forming the Tibetan Plateau: Journal of Geophysical Research, v. 108, doi:10. 1029/2002JB002080.

DeCelles, P. G., Gehrels, G. E., Quade, J., LaReau, B., and Spurlin, M., 2000, Tectonic implications of $\mathrm{U} / \mathrm{Pb}$ zircon ages of the Himalayan orogenic belt in Nepal: Science, v. 288, p. 497-499.

de Jong, K., 2003, Very fast exhumation of high-pressure metamorphic rocks with excess ${ }^{40} \mathrm{Ar}$ and inherited ${ }^{87} \mathrm{Sr}$, Betic Cordilleras, southern Spain: Lithos, v. 70, p. 91-110. 
de Jong, K., Féraud, G., Ruffet, G., Amouric, M., and Wijbrans, J. R., 2001, Excess argon incorporation in phengite of the Mulhacén Complex: submicroscopic illitization and fluid ingress during late Miocene extension in the Betic Zone, south-eastern Spain: Chemical Geology, v. 178, p. 159-195.

de Jong, K., Kurimoto, C., and Guise, P. G., 2000, ${ }^{40} \mathrm{Ar} /{ }^{39} \mathrm{Ar}$ whole-rock dating of metapelites from the Mikabu and Sambagawa belts, western Kii peninsula, southwest Japan: Journal of the Geological Society of Japan, v. 106, p. 703-712.

Didenko, A. N., Massakovsky, A. A., Pecherskii, D. M., Ruzhentsev, S. V., Samygin, S. G., and Kheraskova, T. N., 1994, Geodynamics of the Central-Asian Paleozoic oceans: Russian Geology and Geophisics, v. 35, p. 48-61.

Dobretsov, N. L., 2003, Evolution of structures of the Urals, Kazakhstan, Tien Shan, and Altai-Sayan region within the Ural-Mongolian Fold Belt (Paleoasian Ocean): Russian Geology and Geophisics, v. 44 , p. 5-27.

Dobretsov, N. L., Berzin, N. A., and Buslov, M. M., 1995, Opening and tectonic evolution of the PaleoAsian ocean: International Geology Review, v. 37, p. 335-360.

Dobretsov, N. L., Buslov, M. M., and Vernikovsky, V. A., 2003, Neoproterozoic to Early Ordovician evolution of the Paleo-Asian Ocean: Implications to the break-up of Rodinia: Gondwana Research, v. 6 , p. $143-159$.

Eganov, E. A., and Sovetov, Yu. K., 1979, Karatau - a model for phosphorite deposition, in Siberian Branch, USSR Academy of Sciences, editor, Transactions of the Institute of Geology and Geophysics, v. 427: Novosibirsk, Nauka Publishing House, 190 p (in Russian with English abstract).

Ehiro, M., 2000, Relationships in tectonic framework among the South Kitakami and Hayachine tectonic belts, Kurosegawa Belt, and "Paleo-Ryoke Belt": Memoir of the Geological Society of Japan, v. 56, p. 53-64. 
Ehiro, M., Hasegawa, H., and Misaki, A., 2005, Permian ammonoids Prostacheocers and Perrinites from the Southern Kitakami Massif, Northeast Japan: Journal of Paleontology: v. 79, p. 1222-1228.

Faure, M., and Charvet, J., 1987, Late Permian/early Triassic orogeny in Japan: piling up of nappes, transverse lineation and continental subduction of the Honshu block: Earth and Planetary Science Letters, v. 84, p. 295-308.

Filippova, I. B., Bush, V. A., and Didenko, A. N., 2001, Middle Paleozoic subduction belts: The leading factor in the formation of the Central Asian fold-and-thrust belt: Russian Journal of Earth Sciences, v. 3, p. $405-426$.

Findlay, R. H., 1998, The Song Ma Anticlinorium, northern Vietnam: the structure of an allochtonous terrane containing an early Palaeozoic island arc sequence: Journal of Asian Earth Sciences, v. 15, p. 453-464.

Fortey, R. A., and Cocks, L. R. M., 2003, Palaeontological evidence bearing on global Ordovician-Silurian continental reconstructions: Earth-Science Reviews, v. 61, p. 245-307.

Foster, D. A., Gray, D. R., and Spaggiari, C. V., 2005, Timing of subduction and exhumation along the Cambrian east Gondwana margin, and the formation of Paleozoic backarc basins: Geological Society of America Bulletin, v. 117, p. 105-116.

Gao, J., and Klemd, R., 2003, Formation of HP-LT rocks and their tectonic implications on the western Tianshan orogen, NW China: geochemical and age constraints: Lithos, v. 66, p. 1-22.

Gao, J., Li, M. S., Xiao, X. C., Tang, Y. Q., and He, G. Q., 1998, Palaeozoic tectonic evolution of the Tianshan Orogen, northwestern China: Tectonophysics, v. 287, p. 213-231.

Gao, S., Zhang, B. R., Gu, X. M., Xie, Q. L., Gao, C. L., and Guo, X. M., 1995, Silurian-Devonian provenance changes of South Qinling basins: implications for accretion of the Yangtze (South China) to the North China cratons: Tectonophysics, v. 250, p. 183-197. 
Gehrels, G. E., DeCelles, P. G., Martin, A., Ojha, T. P., Pinhassi, G., and Upreti, B. N., 2003, Initiation of the Himalayan orogen as an arly Paleozoic thin-skinned thrust belt: GSA Today, v. 13, p. 4-9. doi: 10.1130/1052-5173(2003)13<4:IOTHOA $>2.0$. CO;2

Gehrels, G.E., DeCelles, P.G., Ojha, T.P., and Upreti, B.N., 2006a, Geologic and U-Th-Pb geochronologic evidence for early Paleozoic tectonism in the Kathmandu thrust sheet, central Nepal Himalaya: Geological Society of America Bulletin, v. 118, p. 185-198. doi: 10.1130/B25753.1

Gehrels, G.E., DeCelles, P.G., Ojha, T.P., and Upreti, B.N., 2006b, Geologic and U-Pb geochronologic evidence for early Paleozoic tectonism in the Dadeldhura thrust sheet, far-west Nepal Himalaya: Journal of Asian Earth Sciences, v. 28, p. 385-408. doi:10.1016/j.jseaes.2005.09.012

Guo, F., Fan, W. M., Wang, Y. J., and Li, C. W., 2004, Upper Paleozoic basalts in the Southern Yangtze Block: Geochemical and $\mathrm{Sr}-\mathrm{Nd}$ isotopic evidence for asthenosphere-lithosphere interaction and opening of the Paleo-Tethyan Ocean: International Geology Review, v. 46, p. 332-346.

Hada, S., Ishii, K. -i., Landis, C. A., Aitchison, J., and Yoshikura, S., 2001, Kurosegawa Terrane in Southwest Japan: Disrupted remnants of a Gondwana-derived terrane: Gondwana Research, v. 4, p. $27-38$.

Hada, S., Yoshikura, S. and Gabites, J. F., 2000, U-Pb zircon ages for the Mitaki igneous rocks, SiluroDevonian tuff, and granitic boulders in the Kurosegawa Terrane, Southwest Japan: Memoir of the Geological Society of Japan, v. 56, p. 183-198.

Hamano, K., Iwata, K., Kawamura, M., and the Kitakami Paleozoic Research Group, 2002, Late Devonian conodont age of red chert intercalated in greenstones of the Hayachine Belt, Northeast Japan: Journal of the Geological Society of Japan, v. 108, p. 114-122. (in Japanese with English abstract).

Hammerschmidt, K., and Franz, G., 1992, Retrograde evolution of eclogites: evidences from microstructures and ${ }^{40} \mathrm{Ar} /{ }^{39} \mathrm{Ar}$ white mica dates, Münchberg Massif, northern Bavaria: Contributions to Mineralogy and Petrology, v. 111, p. 113-125. 
Han, B. F., He, G. Q., Wu, T. R., and Li, H. M., 2004, Zircon U-Pb dating and geochemical features of Early Paleozoic granites from Tianshan, Xinjiang: Implications for tectonic evolution: Xinjiang Geology, v. 22, p. 4-11 (in Chinese with English abstract).

Hannula, K. A., and McWilliams, M. O., 1995, Reconsideration of the age of blueschist facies metamorphism on the Seward Peninsula, Alaska, based on phengite ${ }^{40} \mathrm{Ar} /{ }^{39} \mathrm{Ar}$ results: Journal of Metamorphic Geology, v. 13, p. 125-139.

Harland, W. B, Armstrong, R. L, Cox, A. V, Craig, L. E, Smith, A. G, and Smith, D. G, 1990, A Geological Time Scale 1989: Cambridge, Cambridge University Press, 263 p.

Heizler, M. T., and Harrison, T. M., 1988, Multiple trapped argon isotope components revealed by ${ }^{40} \mathrm{Ar} /{ }^{39} \mathrm{Ar}$ isochron analysis: Geochimica et Cosmochimica Acta, v. 52, p. 1295-1303.

Hsü, K. J., Wang, Q., Li, J., and Hao, J., 1991, Geologic evolution of the Neimonides: a working hypothesis: Eclogae Geologicae Helvetiae, v. 84, p. 1-31.

$\mathrm{Hu}, \mathrm{X} ., \mathrm{Xu}, \mathrm{C}$. , and Niu, S., 1990, Evolution of the Early Palaeozoic Continental Margin in Northern Margin of the North China Platform: Beijing, Peking University Press, $216 \mathrm{p}$ (in Chinese with English abstract).

Ishiwatari, A., and Tsujimori, T., 2003, Paleozoic ophiolites and blueschists in Japan and Russian Primorye in the tectonic framework of East Asia: A synthesis: The Island Arc, v. 12, p. 190-206.

Isozaki, Y., 1997a, Contrasting two types of orogen in Permo-Triassic Japan: Accretionary versus Collisional: The Island Arc, v. 6, p. 2-24.

Isozaki, Y., 1997b, Jurassic accretion tectonics of Japan: The Island Arc, v. 6, p. 25-51.

Jahn, B-M., 2004, The Central Asian Orogenic Belt and growth of the continental crust in the Phanerozoic, in Malpas, J., Fletcher, C. J. N., Aitchison, J. C., editors, Aspects of the Tectonic Evolution of China: Geological Society London Special Pubublication, No. 226, p. 73-100. 
Jahn, B-M., Wu, F., and Chen, B., 2000, Granitoids of the Central Asian Orogenic Belt and continental growth in the Phanerozoic: Transactions of the Royal Society of Edinburgh: Earth Sciences, v. 91, p. 181-193.

Jia, D. C., Hu, R., Lu, Y., and Qiu, X., 2004, Collision belt between the Khanka block and the North China block in the Yanbian Region, Northeast China: Journal of Asian Earth Sciences, v. 23, p. 211-219.

Jian, P., Lui, D., Kröner, A., 2006, Early Paleozoic Ridge - Trench Interaction in the Central Asian Orogenic Belt of Inner Mongolia, China: Asia Oceania Geosciences Society $3^{\text {rd }}$ Annual Meeting, Singapore 10-14 July 2006 (AOGS 2006), www.asiaoceania-conference.org/Abstract2006/Abstract File $\backslash S E \backslash S E 20 \backslash 59-S E-A 0880$.

Kawajiri, K., 2005, Petrology of gabbroic rocks in the Hida Gaien belt in the northern part of Takayama City, Gifu Prefecture, central Japan: Journal of the Geological Society of Japan, v. 111, p. 332-349 (in Japanese with English abstract).

Khain, E. V., Bibikova, E. V., Salnikova, E. B., Kröner, A., Gibsher, A. S., Didenko, A. N., Degtyarev, K. E., and Fedotova, A. A., 2003, The Palaeo-Asian ocean in the Neoproterozoic and early Palaeozoic: new geochronologic data and palaeotectonic reconstructions: Precambrian Research, v. 122, p. 329358.

Khanchuk, A. I., Ratkin, V. V., Ryazantseva, M. D., Golozubov, V. V., and Gonokhova, N. B., 1996, Geology and mineral deposits of Primorskiy Krai: Vladivostok, Russian Academy of Sciences, Geological Institute, Far East Branch, Dalnauka, 61 p.

Kheraskova, T. N., Didenko, A. N., Bush, V. A., Volozh, and Yu. A., 2003, The Vendian-Early Paleozoic history of the continental margin of Eastern Paleogondwana, Paleoasian Ocean, and Central Asian Foldbelt: Russian Journal of Earth Sciences, v. 5, p. 165-184.

Kojima, S., Kemkin, I. V., Kametaka, M., and Ando, A., 2000, A correlation of accretionary complexes of southern Sikhote-Alin of Russia and the Inner Zone of Southwest Japan: The Geoscience Journal, v. 4, p. 175-185. 
Kretz, R., 1983, Symbols for rock-forming minerals: American Mineralogist, v. 68, p. 277-279.

Kurihara, T., 2004, Silurian and Devonian radiolarian biostratigraphy of the Hida Gaien belt, central Japan: Journal of the Geological Society of Japan, v. 110, p. 620-639 (in Japanese with English abstract).

Kusky, T. M., and Li, J., 2003, Paleoproterozoic tectonic evolution of the North China Craton: Journal of Asian Earth Sciences, v. 22, p. 383-397.

Lan, C. -Y., Chung, S. -L., Trinh, V. L., Lo, C. -H., Lee, T. -Y., Mertzman, S. A., and Shen, J. J. -S., 2003, Geochemical and Sr-Nd isotopic constraints from the Kontum massif, central Vietnam on the crustal evolution of the Indochina block: Precambrian Research, v. 122, p. 7-27.

Laurent-Charvet, S., Charvet, J., Shu, L. S., Ma, R., and Lu, H., 2002, Palaeozoic late collisional strike-slip deformations in Tianshan and Altay, Eastern Xinjiang, NW China: Terra Nova, v. 14, p. 249-256.

Laurent-Charvet, S., Charvet, J., Monié, P., and Shu, L. S., 2003, Late Palaeozoic strike-slip shear zones in eastern central Asia (NW China): New structural and geochronological data: Tectonics, v. 22, doi:10.1029/2001TC901047.

Le Fort, P., Tongiorgi, M., Gaetani, M., 1994, Discovery of a crystalline basement and Early Ordovician marine transgression in the Karakorum mountain range, Pakistan; Geology, v. 22, p. 941-944. doi: 10.1130/0091-7613(1994)022<0941:DOACBA $>2.3 . C O ; 2$

Li, J. -Y. 2006, Permian geodynamic setting of Northeast China and adjacent regions: closure of the PaleoAsian Ocean and subduction of the Paleo-Pacific Plate: Journal of Asian Earth Sciences, v. 26, p. 207-224.

Li, X., Wu, X., 1996, Late Paleozoic phytogeographic provinces in China and its adjacent regions: Review of Palaeobotany and Palynology, v. 90, p. 41-62.

Li, Z. X., and Powell, C. McA., 2001, An outline of the palaeogeographic evolution of the Australasian region since the beginning of the Neoproterozoic: Earth-Science Reviews, v. 53, p. 237-277. 
Li, W. P., Wang, T., Li, J. B., Kang, X., Yu, F. S., Han, Q. J., and Ma, Z. P., 2001, The U-Pb age of zircon from Late Caledonian granitoids in Hongliuhe area, East Tienshan mountains, Northwest China and its geological implications: Acta Geolscientia Sinica, v. 22, p. 231-235.

Liou, J. G., Tsujimori, T., Zhang, R. Y., Katayama, I., Maruyama, S., 2004. Global UHP metamorphism and continental subduction/collision: The Himalayan model: International Geology Review, v. 46, p. $1-27$.

Liu, Y. J., ms, 2000, ${ }^{40} \mathrm{Ar} /{ }^{39} \mathrm{Ar}$ geochronology and P-T-t paths constraining tectonic processes in orogenic belts: Results from Qilian and Kunlun Mountains (Western China) and Radstadt Mountains (Eastern Alps, Austria): Ph.D. thesis, University of Salzburg, Austria, 100 p.

Lo, C. H., and Lee, C. Y., 1994, ${ }^{40} \mathrm{Ar} /{ }^{39} \mathrm{Ar}$ method of $\mathrm{K}-\mathrm{Ar}$ age determination of geological samples using Tsing-Hua Open-Pool (THOR) Reactor: Journal of the Geological Society of China, v. 37, p. 143164.

Ludwig, K. R., 2000, Isoplot/Ex version 2. 3. A geochronological toolkit for Microsoft Excel: Berkeley Geochronlogy Center, Special publication, No. 1a, 54 p.

Mao, J., Zhang, Z., Lehmann, B., Zhang, Z., Yang J., and Wang Z., 2000, The Yeniutan granodiorite in Sunan County, Gansu Province, China: petrological features, geological setting and relationship to tungsten mineralization, Episodes, vol. 23, p. 163-171.

Mao, J., Zhang, Z., Zhang, Z., and Du, A., 1999, Re-Os isotopic dating of molybdenites in the Xiaoliugou W (Mo) deposit in the northern Qilian mountains and its geological significance: Geochimica et Cosmochimica Acta, v. 63, p. 1815-1818.

Maruyama, S., Cho, M., and Liou, J. G., 1986, Experimental investigations of blueschist-greenschist transition equilibria: pressure dependence of $\mathrm{Al}_{2} \mathrm{O}_{3}$ contents in sodic amphiboles - a new geobarometer, in Evans, B. W., and Brown, E. H., editors, Blueschists and Eclogites: Geological Society of America Memoir, v. 164, p. 1-16. 
Maruyama, S., Isozaki, Y., Kimura, G., and Terabayashi, M., 1997, Paleogeographic maps of the Japanese Islands: Plate tectonic synthesis from 750 Ma to the present: The Island Arc, v. 6, p. 121-142.

Matte, Ph., Tapponnier, P., Arnaud, N., Bourjot, L., Avouac, J. P., Vidal, Ph., Liu, Q., Pan, Y. S., and Wang, Y., 1996, Tectonics of Western Tibet, between the Tarim and the Indus: Earth and Planetary Science Letters, v. 142, p. 311-330.

Mattern, F., and Schneider, W., 2000, Suturing of the Proto- and Paleo-Tethys oceans in the western Kunlun (Xinjiang, China): Journal of Asian Earth Sciences, v. 18, p. 637-650.

Meert, J. G., Nédélec, A., Hall, C., Wingatee, M. T. D., and Rakotondrazafy, M., 2001, Paleomagnetism, geochronology and tectonic implications of the Cambrian-age Carion granite, Central Madagascar: Tectonophysics, v. 340, p. 1-21.

Metcalfe, I., 1996, Gondwanaland dispersion, Asian accretion and evolution of Eastern Tethys: Australian Journal of Earth Sciences, v. 43, p. 605-623.

Metcalfe, I., 1998, Palaeozoic and Mesozoic geological evolution of the SE Asian region: multidisciplinary constraints and implications for biogeography, in Hall, R., and Holloway, J. D., editors, Biogeography and Geological Evolution of SE Asia: Leiden, Backhuys Publishers, p. 25-41.

Metcalfe, I., 2002, Permian tectonic framework and palaeogeography of SE Asia: Journal of Asian Earth Sciences, v. 20, p. 551-566.

Miller, C., Thöni, M., Frank, W., Grasemann, B., Klötzli, U., Guntli, P., and Draganits, E., 2001, The early Palaeozoic magmatic event in the Northwest Himalaya, India: source, tectonic setting and age of emplacement: Geological Magazine, v. 138, p. 237-251.

Mossakovsky, A. A., Ruzhentsov, S. V., Samygin, S. G., and Kheraskova, T. N., 1994, Central Asian fold belt: geodynamic evolution and formation history: Geotectonics, v. 27, p. 445-473. 
Murphy, J. B., Pisarevsky, S. A., Nance, R. D., Keppie, J. D., 2004, Neoproterozoic-Early Paleozoic evolution of peri-Gondwanan terranes: implications for Laurentia-Gondwana connections: International Journal of Earth Sciences, v. 93, p. 659-682.

Nagy, E. A., Maluski, H., Lepvrier, C., Schärer, U., Thi, P. T., Leyreloup, A., and Thich, V. V., 2001, Geodynamic significance of the Kontum massif in central Vietnam: composite ${ }^{40} \mathrm{Ar} /{ }^{39} \mathrm{Ar}$ and $\mathrm{U}-\mathrm{Pb}$ ages from Paleozoic to Triassic: The Journal of Geology, v. 109, p. 755-770.

Nakajima, T., 1997, Regional metamorphic belts of the Japanese islands: The Island Arc, v. 6, p. 69-90.

Nie, F., and Bjørlykke, A., 1999, Nd and Sr isotope constraints on the age and origin of Proterozoic metamafic volcanic rocks in the Bainaimiao-Wenduermiao district, south-central Inner Mongolia, China: Continental Dynamics, v. 4, p. 1-14.

Nishimura, Y., 1998, Geotectonic subdivision and areal extent of the Sangun belt, Inner Zone of Southwest Japan: Journal of metamorphic Geology, v. 16, p. 129-140.

Nitsch, K. -H., 1972, Das P-T-X-CO2 Stabilitäts-feld von Lawsonit: Contributions to Mineralogy and Petrology, v. 34, p. 116-344.

Nokleberg, W. J., Badarch, G., Berzin, N. A., Diggles, M. F., Hwang, D. H., Khanchuk, A. I., Miller, R. J., Naumova, V. V., Obolenskiy, A. A., Ogasawara, M., Parfenov, L. M., Prokopiev, A. V., Rodionov, S. M., and Yan, H., editors, 2004, Digital Files for Northeast Asia Geodynamics, Mineral Deposit Location, and Metallogenic Belt Maps, Stratigraphic Columns, Descriptions of Map Units, and Descriptions of Metallogenic Belts: United States Geological Survey Open-File Report 2004-1252, http://pubs.usgs.gov/of/2004/1252/of2004-1252.pdf.

Nokleberg, W. J., Parfenov, L. M., Monger, J. W. H., Norton, I. O., Khanchuk, A. I., Stone, D. B., Scotese, C. R., Scholl, D. W., and Fujita, K., 2001, Phanerozoic tectonic evolution of the Circum-North Pacific: United States Geological Survey Professional Paper 1626, 122 p. 
Odin, G. S., and 35 collaborators, 1982, Interlaboratory standards for dating purposes, in Odin, G. S., editor, Numerical Dating in Stratigraphy: New York, Wiley and Sons, p. 123-148.

Oh, C. W., Kim, S. W., Choi, S. G., Zhai, M., Guo, J., and Krishnan, S., 2005, First finding of eclogite facies metamorphic event in South Korea and its correlation with the Dabie-Sulu collision belt in China: The Journal of Geology, v. 113, p. 226-232.

Okay, A. I., and Monié, P., 1997, Early Mesozoic subduction in the Eastern Mediterranean: Evidence from Triassic eclogite in northwest Turkey: Geology, v. 25, p. 595-598.

Ota, T., Buslov, M. M., and Watanabe, T., 2002, Metamorphic evolution of Late Precambrian eclogites and associated metabasites, Gorny Altai, southern Russia: International Geology Review, v. 44, p. 837858.

Peng, L. H., 1984, The age of ophiolite suite in Ondor Sum Group, Inner Mongol, and its tectonic significance: Kexue Tongbao, v. 2, p. 104-107 (in Chinese).

Pickering, K. T., and Smith, A. G., 1995, Arcs and backarc basins in the Early Paleozoic Iapetus Ocean: The Island Arc, v. 4, p. 1-67.

Qian, Q., and Zhang, Q., 2001, Geochemical characteristics and tectonic setting of the Laohushan basalts, North Qilian mountains: Acta Geologica Sinica, v. 75, p. 452-457.

Qiu, H. N., Wijbrans, J. R., 2006, Paleozoic ages and excess ${ }^{40} \mathrm{Ar}$ in garnets from the Bixiling eclogite in Dabieshan, China: New insights from ${ }^{40} \mathrm{Ar} /{ }^{39} \mathrm{Ar}$ dating by stepwise crushing: Geochimica et Cosmochimica Acta, v. 70, p. 2354-2370.

Ramezani, J., and Tucker, R. D., 2003, The Saghand Region, Central Iran: U-Pb geochronology, petrogenesis and implications for Gondwana Tectonics: American Journal of Science, v. 303, p. 622665. 
Ratschbacher, L., Hacker, B. R., Calvert, A., Webb, L. E., Grimmer, J. C., McWilliams, M. O., Ireland, T., Dong, S., and Hu J., 2003, Tectonics of the Qinling (Central China): tectonostratigraphy, geochronology, and deformation history: Tectonophysics, v. 366, p. 1-53.

Renne, P. R., Swisher, C. C., Deino, A. L., Karner, D. B., Owens, T. L., and DePaolo, D. J., 1998, Intercalibration of standards, absolute ages and uncertainties in ${ }^{40} \mathrm{Ar}{ }^{39} \mathrm{Ar}$ dating: Chemical Geology, v. 145 , p. $117-152$.

Roddick, J. C., Cliff, R. A., and Rex, D. C., 1980, The evolution of excess argon in Alpine biotites - A ${ }^{40} \mathrm{Ar}{ }^{39} \mathrm{Ar}$ analysis: Earth and Planetary Science Letters, v. 48, p. 185-208.

Rodríguez, J., Cosca, M. A., Gil Ibarguchi, J. I., and Dallmeyer, R. D., 2003, Strain partitioning and preservation of ${ }^{40} \mathrm{Ar} /{ }^{39} \mathrm{Ar}$ ages during Variscan exhumation of a subducted crust (Malpica-Tui complex, NW Spain): Lithos, v. 70, p. 111-139.

Roger, F., Arnaud, N., Gilder, S., Tapponnier, P., Jolivet, M., Brunel, M., Malavieille, J., Xu, Z., and Yang, J., 2003, Geochronological and geological constraints on Mesozoic suturing in east central Tibet: Tectonics, v. 22, doi:10.1029/2002TC001466.

Roger, F., Leloup, P. H., Jolivet, M., Lacassin, R., Phan T. T., Brunel, M., and Seward, D., 2000, Long and complex thermal history of the Song Chay metamorphic dome (northern Vietnam) by multi-system geochronology: Tectonophysics, v. 321, p. 449-466.

Rolland, Y., Picard, C., Pêcher, A., Carrio, E., Sheppard, S. M. F., Oddone, M., and Villa, I. M., 2002, Presence and geodynamic significance of Cambro-Ordovician series of SE Karakoram (N Pakistan): Geodinamica Acta, v. 15, p. 1-21.

Ruffet, G., Féraud, G., Ballèvre, M., and Kiénast, J. R., 1995, Plateau ages and excess argon in phengites: an ${ }^{40} \mathrm{Ar}-{ }^{39} \mathrm{Ar}$ laser probe study of Alpine micas (Sesia zone, Western Alps, northern Italy): Chemical Geology, v. 121, p. 327-343. 
Sakashima, T., Terada, K., Takeshita, T., and Sano, Y., 2003, Large-scale displacement along the Median Tectonic Line, Japan: evidence from SHRIMP zircon $\mathrm{U}-\mathrm{Pb}$ dating of granites and gneisses from the South Kitakami and paleo-Ryoke belts: Journal of Asian Earth Sciences, v. 21, p. 1019-1039.

Scaillet, S., 1996, Excess ${ }^{40}$ Ar transport scale and mechanism in high-pressure phengites: a case study from eclogitized metabasite of the Dora-Maira nappe, western Alps: Geochimica et Cosmochimica Acta, v. 60 , p. $1075-1090$.

Schaltegger, U., Abrecht, J., and Corfu, F., 2003, The Ordovician orogeny in the Alpine basement: constraints from geochronology and geochemistry in the Aar Massif (Central Alps): Schweizerische Mineralogische und Petrographische Mitteilungen, v. 83, p. 183-195.

Schwab, M., Ratschbacher, L., Siebel, W., McWilliams, M., Minaev, V., Lutkov, V., Chen, F., Stanek, K., Nelson, B., Frisch, W., and Wooden, J. L., 2004, Assembly of the Pamirs: Age and origin of magmatic belts from the southern Tien Shan to the southern Pamirs and their relation to Tibet: Tectonics, v. 23, doi:10.1029/2003TC001583.

Şengör, A. M. C., and Natal'in, B. A., 1996, Paleotectonics of Asia, in Yin, A., and Harrison, T. M., editors, The Tectonic Evolution of Asia: Cambridge, Cambridge University Press, p. 486-640.

Şengör, A. M. C., Natal'in, B. A., and Burtman, V. S., 1993, Evolution of the Altaid tectonic collage and Palaeozoic crustal growth in Eurasia: Nature, v. 364, p. 299-307.

Shang, Q., 2004, Occurrences of Permian radiolarians in central and eastern Neimongol (Inner Mongolia) and their geological significance for the North China Orogen: Chinese Science Bulletin, v. 49, p. 2613-2619.

Shao, J., 1989, Continental crust accretion and tectono-magmatic activity at the northern margin of the Sino-Korean plate: Journal of South East Asian Earth Sciences, v. 3, p. 57-62. 
Shu, L. S., Charvet, J., Lu, H. F., and Laurent-Charvet, S., 2002, Palaeozoic accretion-collision events and kinematics of ductile deformation in the eastern part of the southern-Central Tianshan belt, China: Journal of the Geological Society of China, v. 76, p. 308-323.

Shu, L. S., Yu, J., Charvet, J., Laurent-Charvet, S., Sang, H., and Zhang, R., 2004, Geological, geochronological and geochemical features of granulites in the Eastern Tianshan, NW China: Journal of Asian Earth Sciences, v. 24, p. 25-41.

Sisson, V. B., and Onstott, T. C., 1986, Dating blueschist metamorphism: A combined ${ }^{40} \mathrm{Ar} /{ }^{39} \mathrm{Ar}$ and electron microprobe approach: Geochimica et Cosmochimica Acta, v. 50, p. 2111-2117.

Song, S. G., and Wu, H. Q., 1992, Ductile shearing of subduction complex belt in North Qilian Mountains, China: Northwest Geoscience, v. 13, p. 47-60 (in Chinese with English abstract).

Song, S. G., Yang, J. S., Liou, J. G., Wu, C. L., Shi, R. D., and Xua, Z. Q., 2003, Petrology, geochemistry and isotopic ages of eclogites from the Dulan UHPM Terrane, the North Qaidam, NW China: Lithos, v. 70 , p. $195-211$.

Steiger, R. H., and Jäger, E., 1977, Subcommission on geochronology: Convention on the use of decay constants in geo- and cosmochronology: Earth and Planetary Science Letters, v. 36, p. 359-362.

Sun, W., Li, S., Sun, Y., Zhang, G., and Li, Q., 2002a, Mid-paleozoic collision in the north Qinling: Sm$\mathrm{Nd}, \mathrm{Rb}-\mathrm{Sr}$ and ${ }^{40} \mathrm{Ar} /{ }^{39} \mathrm{Ar}$ ages and their tectonic implications: Journal of Asian Earth Sciences, v. 21, $69-76$.

Sun, W., Williams, I. S., and Li, S., 2002b, Carboniferous and Triassic eclogites in the western Dabie Mountains, east-central China: evidence for protracted convergence of the North and South China Blocks: Journal of Metamorphic Geology, v. 20, p. 873-886.

Tagiri, M., Yano, T., Bakirov, A., Nakajima, T., and Uchiumi, S. 1995, Mineral parageneses and metamorphic P-T paths of ultrahigh-pressure eclogites from Kyrghyzstan Tien-Shan: The Island Arc, v. 4, p. 280-292. 
Takagi, H., and Arai, H., 2003, Restoration of exotic terranes along the Median Tectonic Line, Japanese Islands: overview: Gondwana Research, v. 6, p. 657-668.

Takasu, A., and Dallmeyer, R. D., 1990, ${ }^{40} \mathrm{Ar}-{ }^{39} \mathrm{Ar}$ age constraints for the tectono-thermal evolution of the Sambagawa metamorphic belt, central Shikoku, Japan: a Cretaceous accretionary prism: Tectonophysics, v. 185, p. 303-324.

Takeuchi, M., 1994, Changes in garnet chemistry show a progressive denudation of the source areas for Permian-Jurassic sandstones, Southern Kitakami Terrane, Japan: Sedimentary Geology, v. 93, p. 85105.

Takeuchi, M., and Suzuki, K., 2000, Permian CHIME ages of leucocratic tonalite clasts from the Middle Permian Usuginu-type conglomerate in the South Kitakami Terrane, northeastern Japan: Journal of the Geological Society of Japan, v. 106, p. 812-815.

Takeuchi, M., Kawai, M., Noda, A., Sugimoto, N., Yokota, H., Kojima, S., Ohno, K., Niwa, M., and Ohba, H., 2004, Stratigraphy of the Permian Shiroumadake Formation and its structural relationship with serpentinite in the Mt. Shiroumadake area, Hida Gaien belt, central Japan: Journal of the Geological Society of Japan, v. 110, p. 715-730.

Tang, K., 1990, Tectonic development of Palaeozoic fold belts at the north margin of the Sino-Korean craton: Tectonics, v. 9, p. 249-260.

Tang, K., 1992, Tectonic evolution and minerogenetic regularities of the fold belt along the northern margins of Sino-Korea Plate. Beijing, Peking University Press, p. 60-65.

Tang, K., and Yan, Z., 1993, Regional metamorphism and tectonic evolution of the Inner Mongolian suture zone: Journal of Metamorphic Geology, v. 11, p. 511-522.

Tang, K., Yan, Z., Zhang, Y., Xu, D., Tchi, Y., Su, Y., and Liang, Z., 1983, On Wentermiao Group and its tectonic significance: Contributions for the Project of Plate Tectonics in Northern China, v. 1, p. 186-208. 
Tazawa, J. -I., 1999, Occurrence of the Boreal-type brachiopod Yakovlevia from the Middle Permian of the Hida Gaien and South Kitakami belts, Japan and its tectonic implications: Journal of the Geological Society of Japan, v. 105, p. 227-230 (in Japanese with English abstract).

Tazawa, J. -I., 2002, Late Paleozoic brachiopod faunas of the South Kitakami Belt, northeast Japan, and their paleobiogeographic and tectonic implications: The Island Arc, v. 11, p. 287-301.

Torsvik, T. H., and Cocks, L. R. M., 2004, Earth geography from 400 to 250 Ma: a palaeomagnetic, faunal and facies review: Journal of the Geological Society, London, v. 161, p. 555-572.

Tsujimori, T., and Itaya, T., 1999, Blueschist-facies metamorphism during Paleozoic orogeny in southwestern Japan: Phengite K-Ar ages of blueschist-facies tectonic blocks in a serpentinite melange beneath early Paleozoic Oeyama ophiolite: The Island Arc, v. 8, p. 190-205.

Tsujimori, T., and Liou, J. G., 2005, Eclogite-facies mineral inclusions in clinozoisite from Paleozoic blueschist, central Chugoku mountains, Southwest Japan: Evidence of regional eclogite-facies metamorphism: International Geology Review, v. 47, p. 215-232.

Tsujimori, T., Liou, J. G., Wooden, J. L., and Miyamoto, T., 2005, U-Pb dating of large zircons in lowtemperature jadeitite from the Osayama serpentinite melange, SW Japan: Insights into the timing of serpentinization: International Geology Review, v. 47, 1048-1057.

Tsukada, K., Takeuchi, M. and Kojima, S., 2004, Redefinition of the Hida Gaien belt: Journal of the Geological Society of Japan, v. 110, p. 640-658 (in Japanese with English abstract).

Umeda, M., 1998, The Siluro-Devonian Yokokurayama Group in the Yokokurayama area, Kochi, Southwest Japan: Journal of the Geological Society of Japan, v. 104, p. 365-376 (in Japanese with English abstract).

Veevers, J. J., 2004, Gondwanaland from 650-500 Ma assembly through 320 Ma merger in Pangea to 185100 Ma breakup: supercontinental tectonics via stratigraphy and radiometric dating: Earth-Science Reviews, v. 68, p. 1-132. 
Villa, I. M., 1998, Isotopic closure : Terra Nova, v. 10, p. 42-47.

Volkova, N. I., Tarasova, E. N., Polyansky, N. V. and Khomyakov, V. D., 2005, High pressure rocks in serpentinite mélange of the Chara Zone, NE Kazakhstan, in Sklyarov, E. V., editor, Structural and tectonic correlation across the Central Asia orogenic collage: north-eastern segment: Guidebook and abstract volume of the Siberian Workshop IGCP-480. Institute of Earth Crust, Siberian Branch of the Russian Academy of Science, $\quad$ Irkutsk, 269-273. (http://www.igcp.itu.edu.tr/Publications/index.html)

von Raumer, J. F., Stampfli, G. M., and Bussy, F., 2003, Gondwana-derived microcontinents - the constituents of the Variscan and Alpine collisional orogens: Tectonophysics, v. 365, p. 7-22.

Wang, Q., and Liu, X. Y., 1986, Paleoplate tectonics between Cathaysia and Angaraland in Inner Mongolia of China: Tectonics, v. 5, p. 1073-1088.

Wang, B., Faure, M., Shu, L. S., de Jong, K., Cluzel, D., Charvet, J., Meffre, S., and Ruffet, G., 2006. Tectonics of the Yili Block in the southern part of the Western Chinese Tianshan, and its Paleozoic geodynamic evolution. Tectonics, Submitted.

Wang, C. Y., Zhang, Q., Qian, Q., and Zhou, M. -F., 2005, Geochemistry of the Early Paleozoic Baiyin Volcanic Rocks (NW China): Implications for the Tectonic Evolution of the North Qilian Orogenic Belt: The Journal of Geology, v. 113, p. 83-94.

Wang, Z., Sun, S., Li, J., Hou, Q., Qin, K., Xiao, W.-j., and Hao, J., 2003, Paleozoic tectonic evolution of the northern Xinjiang, China: Geochemical and geochronological constraints from the ophiolites: Tectonics, v., 22, doi:10.1029/2002TC001396.

Webby, B. D., Cooper, R. A., Bergström, S. M., and Paris, F., 2004, Stratigraphic framework and time slices, in Webby, B. D., Droser, M. L., Paris, F., and Percival, I. G., editors, The Great Ordovician Biodiversification Event: New York, Columbia University Press, p. 41-47. 
Wijbrans, J.R., and McDougall, I., 1986, ${ }^{40} \mathrm{Ar} /{ }^{39} \mathrm{Ar}$ dating of white micas from an Alpine high-pressure metamorphic belt on Naxos (Greece): the result of resetting of the argon isotopic system: Contributions to Mineralogy and Petrology, v. 93, p. 187-194.

Wilde, S. A., Zhang, X, and Wu, F., 2000, Extension of a newly identified 500 Ma metamorphic terrane in NE China: further U-Pb SHRIMP dating of the Mashan complex, Heilongiiang province, China: Tectonophysics, v. 328, p. 115-130.

Windley, B. F., Allen, M. B., Zhang, C., Zhao, Z. Y., and Wang, G. R., 1990, Palaeozoic accretion and Cenozoic redeformation of the Chinese Tien Shan Range, central Asia: Geology, v. 18, p. 128-131.

Windley, B. F., Kröner, A., Guo, J., Qu, G., Li, Y., and Zhang, C., 2002, Neoproterozoic to Palaeozoic geology of the Altai orogen, Chinese central Asia: New zircon age data and tectonic evolution: The Journal of Geology, v. 110, p. 719-737.

Wu, F. -Y., Sun, D. -Y., Li, H., Jahn, B. -M., and Wilde, S., 2002, A-type granites in northeastern China: age and geochemical constraints on their petrogenesis: Chemical Geology, v. 187, p. 143-173.

Wu, F. -Y., Wilde, S. A., Zhang, G. -L., and Sun, D. -Y., 2004, Geochronology and petrogenesis of the post-orogenic $\mathrm{Cu}-\mathrm{Ni}$ sulfide-bearing mafic-ultramafic complexes in Jilin Province, NE China: Journal of Asian Earth Sciences, v. 23, p. 781-797.

Wu, H. Q., Feng, Y. M., and Song, S. G., 1993, Metamorphism and deformation of blueschist belts and their tectonic implications, North Qilian Mountains: Journal of Metamorphic Geology, v. 11, p. 523536.

Wu, T. R., Zhang, C. and Wan, J. H., 1998, Tectonic settings of Ondor Sum Group and its tectonic interpretation in Ondor Sum region, Inner Mongolia: Geological Journal China University, v. 4, p. 168-176. 
Xi, A., Ren, H., Zhang., B., Wang, Y., Shi, S., and Zhi, H., 2003, Isotopic chronology of the Hulan group and its geological significance in the central Jilin Province: Journal of the Jilin University, v. 33, p. 15-18 (in Chinese).

Xiao, W., Windley, B. F., Hao, J., and Li., J. L., 2002, Arc-ophiolite obduction in the Western Kunlun Range (China): implications for the Palaeozoic evolution of central Asia: Journal of the Geological Society, London, v. 159, p. 517-528.

Xiao, W., Windley, B. F., Hao, J., and Zhai, M., 2003, Accretion leading to collision and the Permian Solonker Suture, Inner Mongolia, China: Termination of the Central Asian Orogenic Belt: Tectonics, v. 22, doi:10.1029/2002TC001484.

Xiao, W., Windley, B. F., Badarch, G., Sun, S., Li, J., Qin, K., and Wang, Z., 2004a, Palaeozoic accretionary and convergent tectonics of the southern Altaids: implications for the growth of Central Asia: Journal of the Geological Society, London, v. 161, p. 339-342.

Xiao, W., Zhang, L., Qin, K., Sun, S., and Li, J., 2004b, Paleozoic accretionary and collisional tectonics of the eastern Tienshan (China): implications for the continental growth of Central Asia: American Journal of Science, v. 304, p. 370-395.

Xiao, W. J., Windley, B. F., Liu, D. Y., Jian, P., Liu, C. Z., Yuan, C., and Sun, M., 2005, Accretionary tectonics of the Western Kunlun orogen, China: A Palaeozoic-Early Mesozoic, long-lived active continental margin with implications for the growth of southern Eurasia: The Journal of Geology, v. 113, p. 687-705.

Xiao, X. C., Tang, Y. Q., and Gao, Y. L., 1986, Re-exposition on plate tectonics of the Qinghai-Xizhang Plateau: Bulletin of the Chinese Academy of Geological Sciences, v. 4, p. 7-20 (in Chinese with English abstract).

Xu, B., Charvet, J., and Zhang, F, 2001, Primary study on petrology and geochronology of blueschists in Sunitezuoqi, northern Inner Mongolia: Chinese The Journal of Geology, v. 36, p. 424-434. 
Xue, F., Kröner, A., Reischmann, T., and Lerch, M., 1996a, Palaeozoic pre- and post-collision calc-alkaline magmatism in the Qinling orogenic belt, central China, as documented by zircon ages on granitoid rocks: Journal of the Geological Society, London, v. 153, p. 409-417.

Xue, F., Lerch, M. F., Kröner, A., and Reischmann, T., 1996b, Tectonic evolution of the East Qinling, China in the Paleozoic: a review and a new tectonic model: Tectonophysics, v. 253, p. 271-284.

Yan, Z., Tang, K., Bai, J., and Mo, Y., 1989, High pressure metamorphic rocks and their tectonic environment in northeastern China: Journal of South East Asian Earth Sciences, v. 3, p. 303-313.

Yang, J. S., Xu, Z. Q., Dobrzhinetskaya, L. F., Green II, H. W., Pei, X. Z., Shi, R. D., Wu, C. L., Wooden, J. L., Zhang, J. X., Wan, Y. S., and Li, H. B., 2003, Discovery of metamorphic diamonds in central China: an indication of a $>4000-\mathrm{km}$-long zone of deep subduction resulting from multiple continental collisions: Terra Nova, v. 15, p. 370-379.

Yang, J. S., Xu, Z. Q., Zhang, J. X., Song, S., Wu, C. L., Shi, R. D., Li, H. B., and Brunel, M., 2002, Early Palaeozoic North Qaidam UHP metamorphic belt on the north-eastern Tibetan plateau and a paired subduction model: Terra Nova, v. 14, p. 397-404.

Yin, A., and Harrison, T. M. 2000, Geologic evolution of the Himalayan-Tibetan orogen: Annual Review of Earth and Planetary Sciences, v.28 p. 211-280.

York, D., 1969, Least squares fitting of a straight line with correlated errors: Earth and Planetary Science Letters, v. 5, p. 320-324.

Yoshida, K., and Machiyama, H., 2004, Provenance of Permian sandstones, South Kitakami Terrane, Northeast Japan: implications for Permian arc evolution: Sedimentary Geology, v. 166, p. 185-207.

Yuan, C., Sun, M., Zhou, M. -F., Zhou, H., Xiao, W. -J., and Li, J. -L., 2002, Tectonic Evolution of the West Kunlun: Geochronologic and Geochemical Constraints from Kudi Granitoids: International Geology Review, v. 44, p. 653-669. 
Zhai, M., Guo, J., Liu, W., 2005, Neoarchean to Paleoproterozoic continental evolution and tectonic history of the North China Craton: a review: Journal of Asian Earth Sciences, v. 24 p. 547-61.

Zhai, M., Shao, J. -a., Hao, J., and Peng, P., 2003, Geological signature and possible position of the North China Block in the supercontinent Rodinia: Gondwana Research, v. 6, p. 171-183.

Zhai, X., Day, H. W., Hacker, B. R., and You, Z., 1998, Paleozoic metamorphism in the Qinling orogen, Tongbai Mountains, central China: Geology, v. 26, p. 371-374.

Zhang, L. F., 1997, ${ }^{40} \mathrm{Ar} /{ }^{39} \mathrm{Ar}$ age and its geological significance of the blueschists from the western Junggar, Xinjiang. Chinese Science Bulletin, v. 42, p. 2178-2181.

Zhang, C., and Wu, T., 1998, Sm-Nd, Rb-Sr isotopic isochron of metamorphic volcanic rocks of Ondor Sum Group, Inner Mongolia: Scientia Geologica Sinica, v. 33, p. 25-30 (in Chinese with English abstract).

Zhang, Y., and Tang, K., 1989, Pre-Jurassic tectonic evolution of intercontinental region and the suture zone between the North China and Siberian platforms: Journal of South East Asian Earth Sciences, v. 3, p. 47-55.

Zhang, Z. M., and Liou, J. G., 1987, The high P/T rocks of China: terrane accretion and orogenic belts: American Geophysical Union Geodynamics Series, v. 19, p. 235-247.

Zhang, A. D., Liu, L., Sun, Y., Chen, D. L., Wang, Y., and Luo, J. H., 2004, SHRIMP U-Pb zircon ages for the UHP metamorphosed granitoid gneiss in Altyn Tagh and their geological significance: Chinese Science Bulletin, v. 49, p. 2527-2532.

Zhang, H. F., Zhang, B. R., Harris, N., Zhang, L., Chen, Y. L., Chen, N. S., and Zhao, Z. D., 2006, U-Pb zircon SHRIMP ages, geochemical and $\mathrm{Sr}-\mathrm{Nd}-\mathrm{Pb}$ isotopic compositions of intrusive rocks from the Longshan-Tianshui area in the southeast corner of the Qilian orogenic belt, China: Constraints on petrogenesis and tectonic affinity: Journal of Asian Earth Sciences, v. 27, p. 751-764. 
Zhang, J. X., Yang, J. S., Mattinson, C. G., Xu, Z. Q., Meng, F. C., and Shia, R. D., 2005, Two contrasting eclogite cooling histories, North Qaidam HP/UHP terrane, western China: Petrological and isotopic constraints: Lithos, v. 84, p. 51-76.

Zhang, J. X., Zhang, Z. M., Xu, Z. Q., Yang, J. S., and Cui, J. W., 2001, Petrology and geochronology of eclogites from the western segment of the Altyn Tagh, Northwestern China: Lithos, v. 56, p. 187206.

Zhang, Q., Sun, X. M., Zhou, D. J., Qian, Q., Chen, Y., Wang, Y. M., Jia, X. Q., and Han, S., 1997, The features and forming environments of ophiolites and their tectonic implication in northern Qilian, China. Progress of Earth Science, Special volume of field symposium on ophiolites and their tectonic setting in Northern Qilian Mountains, v. 4, p. 366-387 (in Chinese with English abstract).

Zhao, G., 2001, Palaeoproterozoic assembly of the North China Craton: Geological Magazine, v. 138, p. $87-91$.

Zhao, G., and Cawood, P. A., 1999, Tectonothermal evolution of the Mayuan assemblage in the Cathaysia Block: Implications for Neoproterozoic collision-related assembly of the South China craton: American Journal of Science, v. 299, p. 309-339.

Zhao, C. J., and Li, Z. T., 1987, The granites of central Nei Mongol in Paleozoic plate tectonics--Collection of papers on plate tectonics of North China: Shengyang, China, Shengyang Institute of Geology and Mineral Resources, Geologic Press, v. 2, p. 80-100 (in Chinese with English abstract).

Zhou, H., Li, J. L., Hou, Q. L., Xiao, W. J., and Chen, H. H., 1999, The large-scale ductile shear zone in Kudi, West Kunlun: Chinese Science Bulletin, v. 44, p. 2080-2082.

Ziegler, P. A. 1989. Evolution of Laurusia - a study of Late Palaeozoic plate tectonics: Dordrecht, Kluwer Academic Publishers, 102 p.

Zonenshain, L. P., Kuz'min, M. I., and Natapov, L. M., 1990, Geology of the USSR: a Plate Tectonic Synthesis: Washington, D. C., American Geophysical Union, Geodynamic Series, v. 21, 242 p. 
Zonenshain, L. P., 1973, The evolution of Central Asian geosynclines through sea-floor spreading: Tectonophysics, v. 19, p. 213-232. 


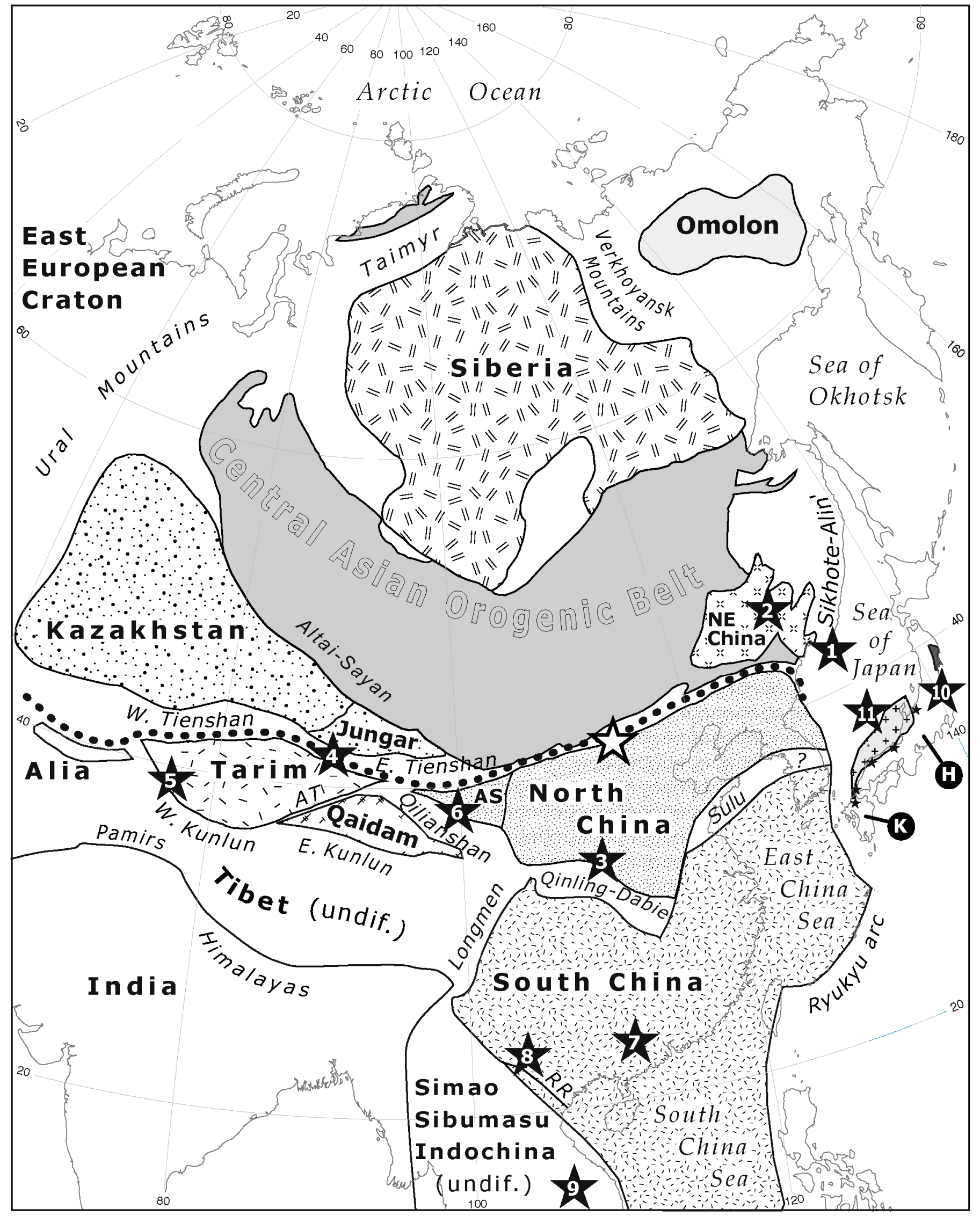




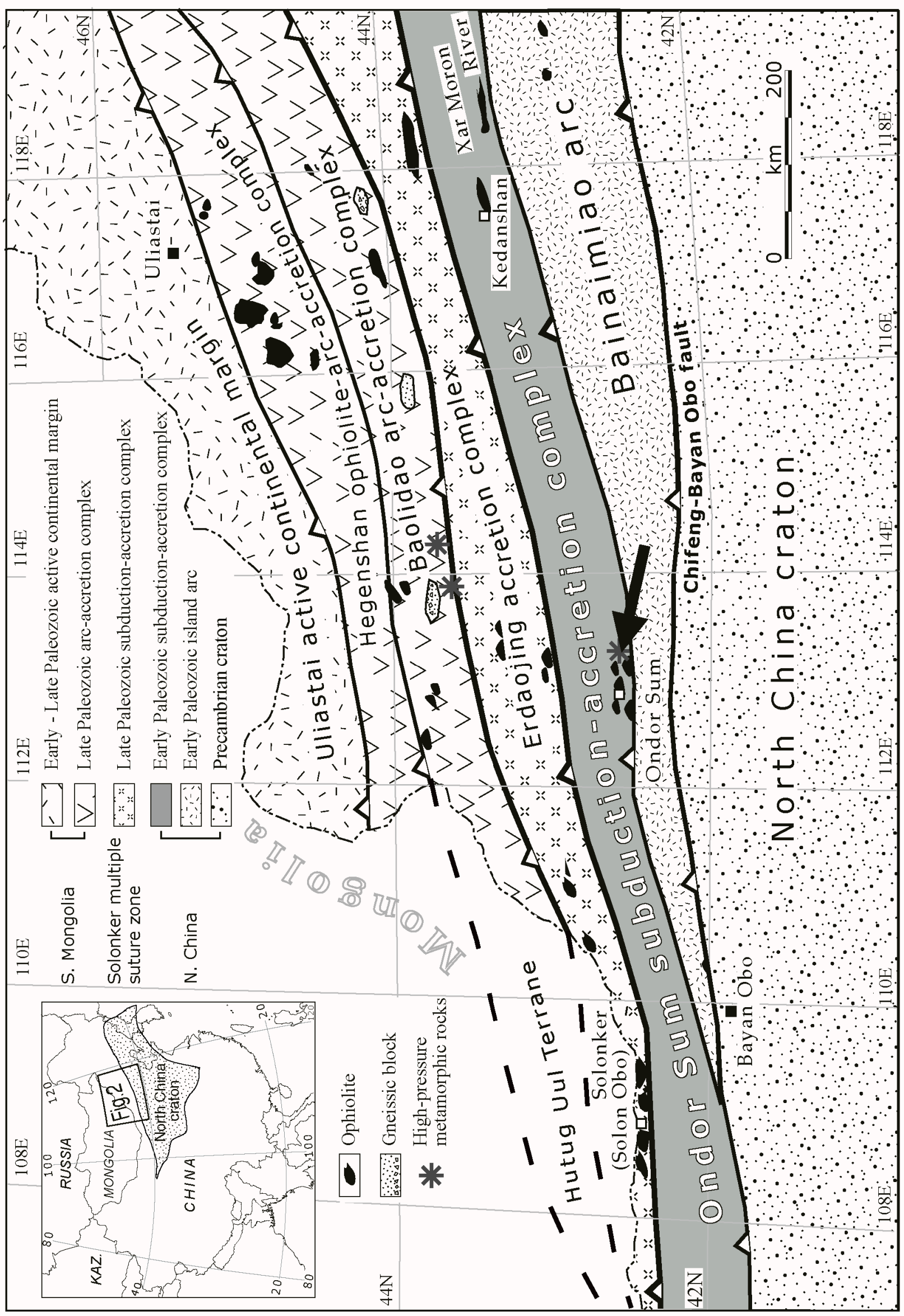




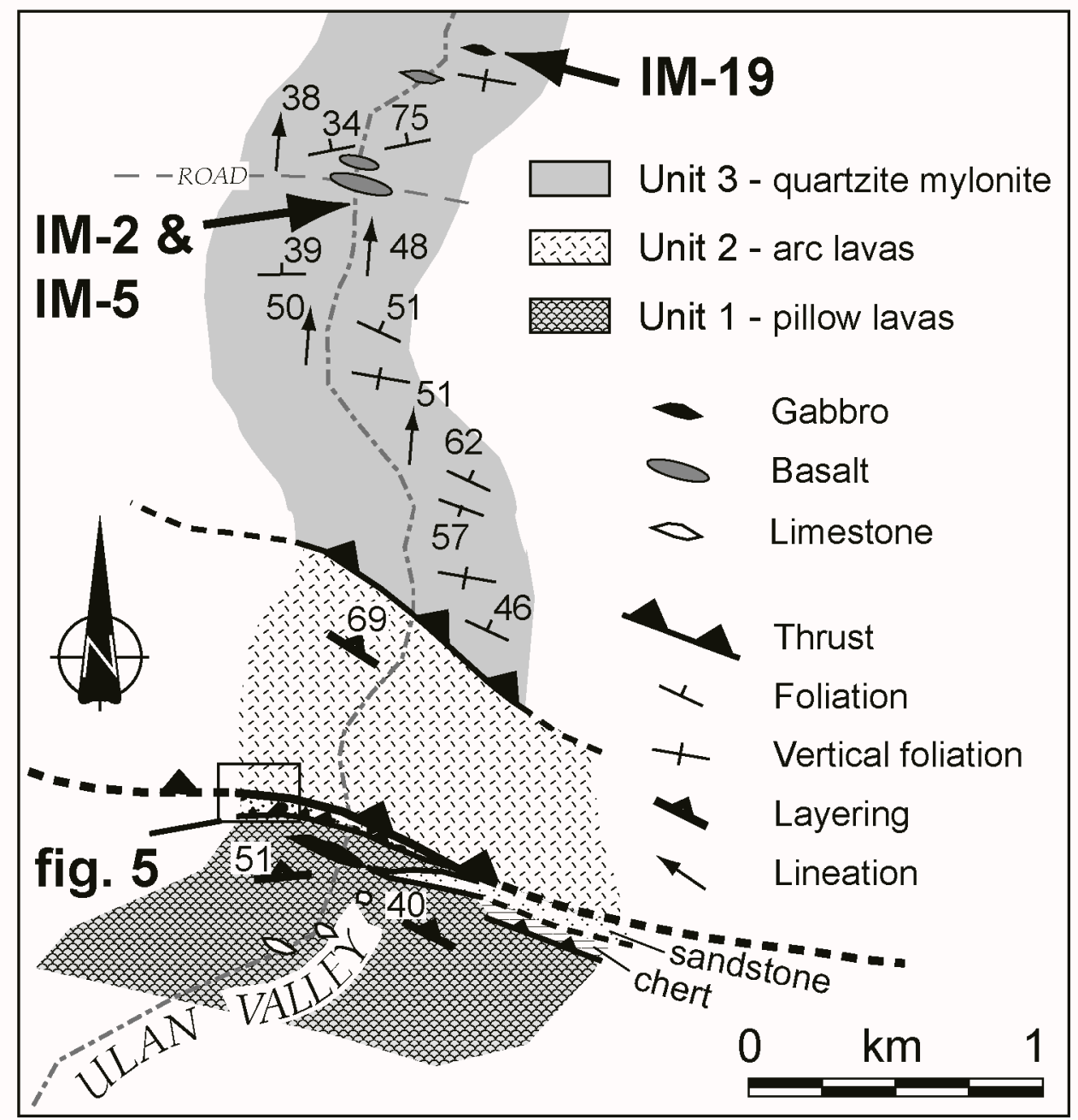


(2)

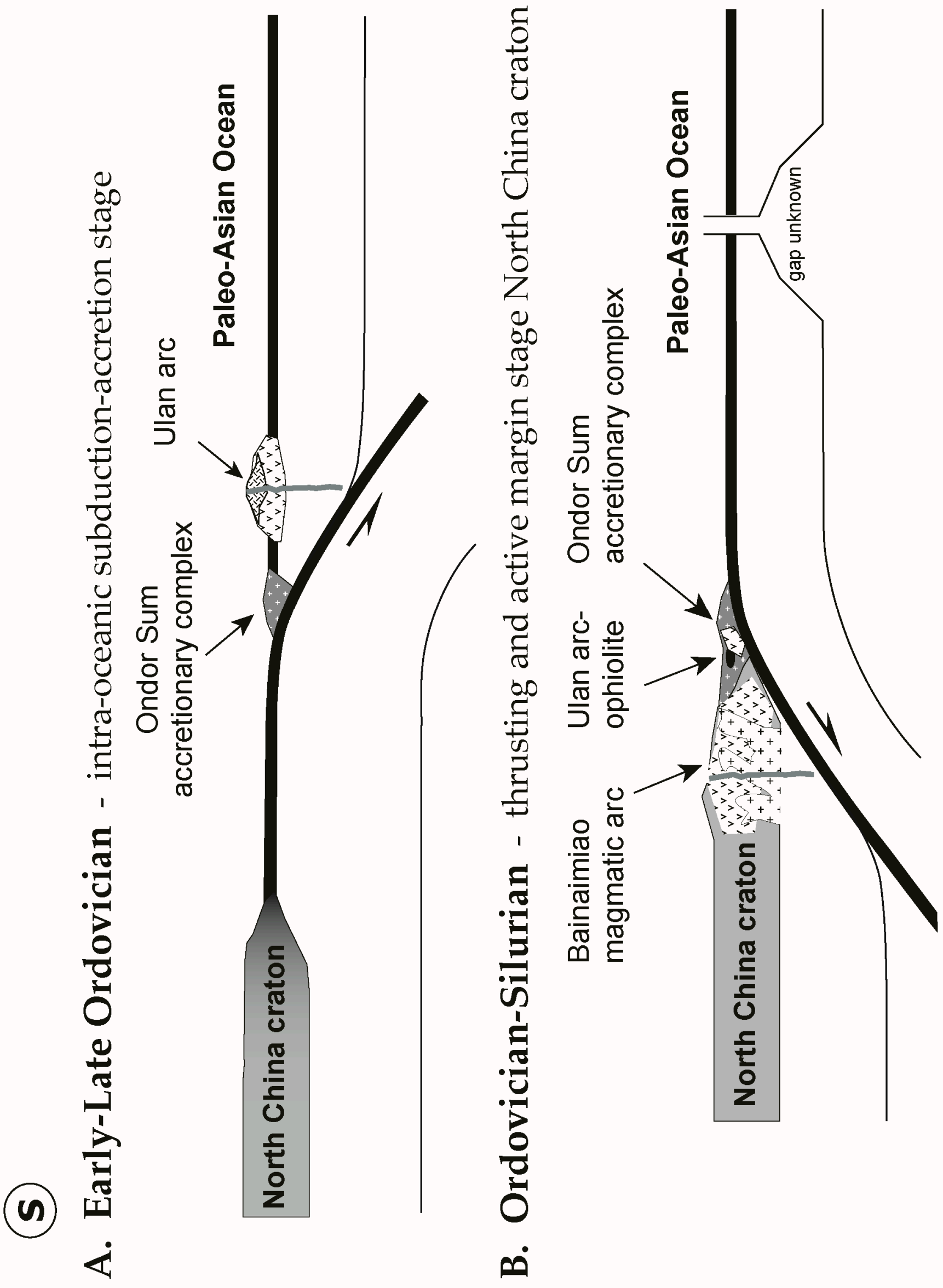




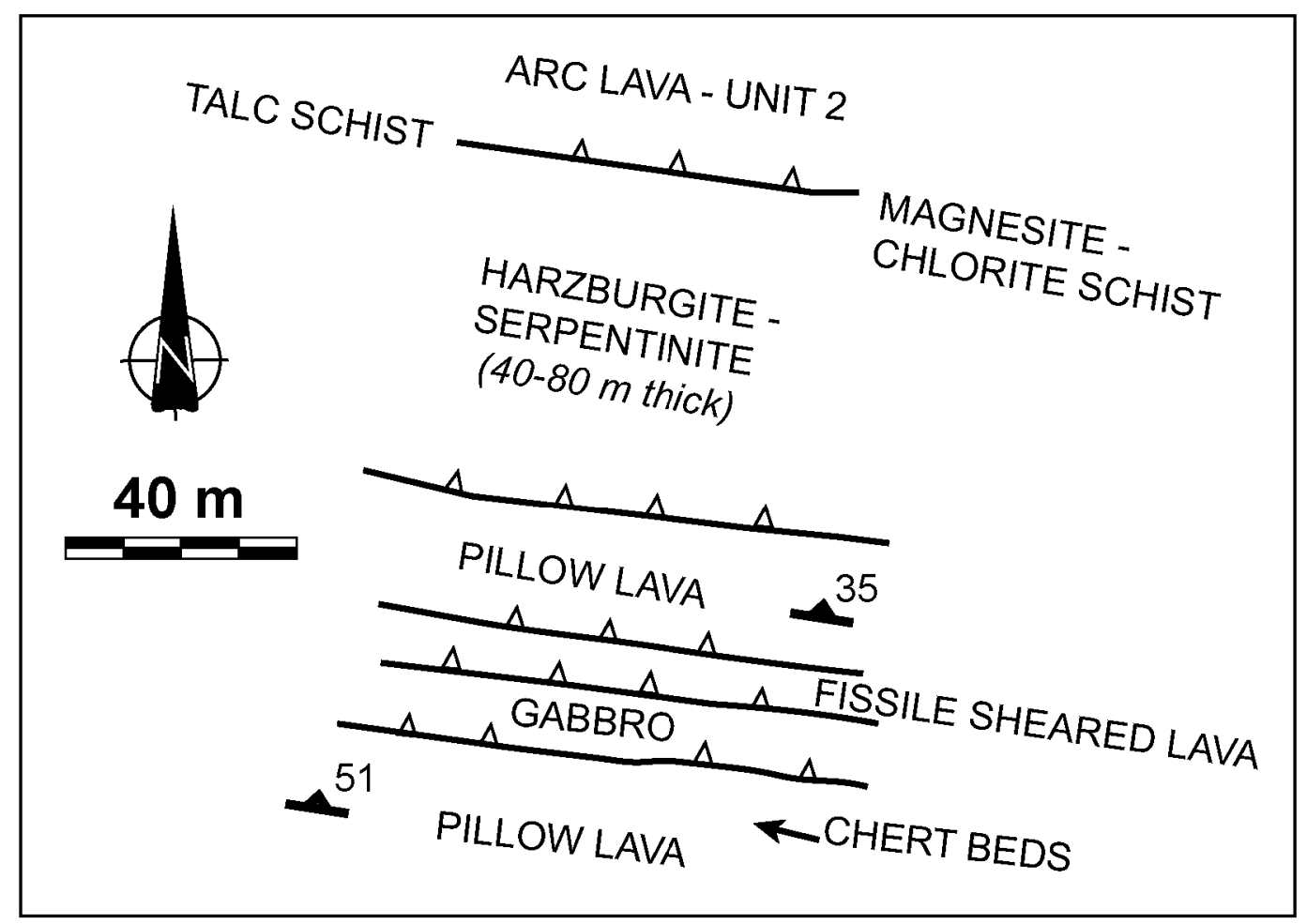




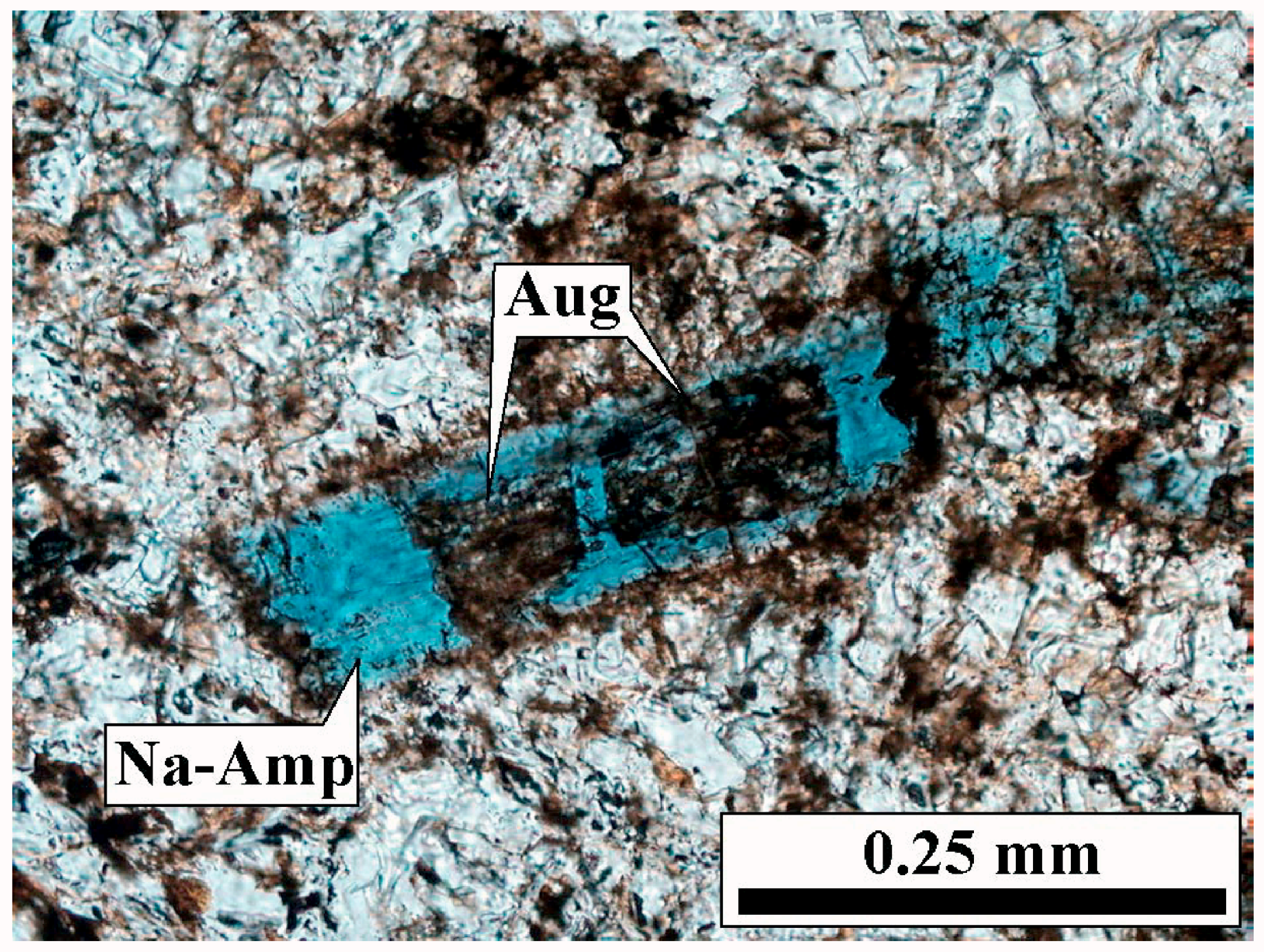



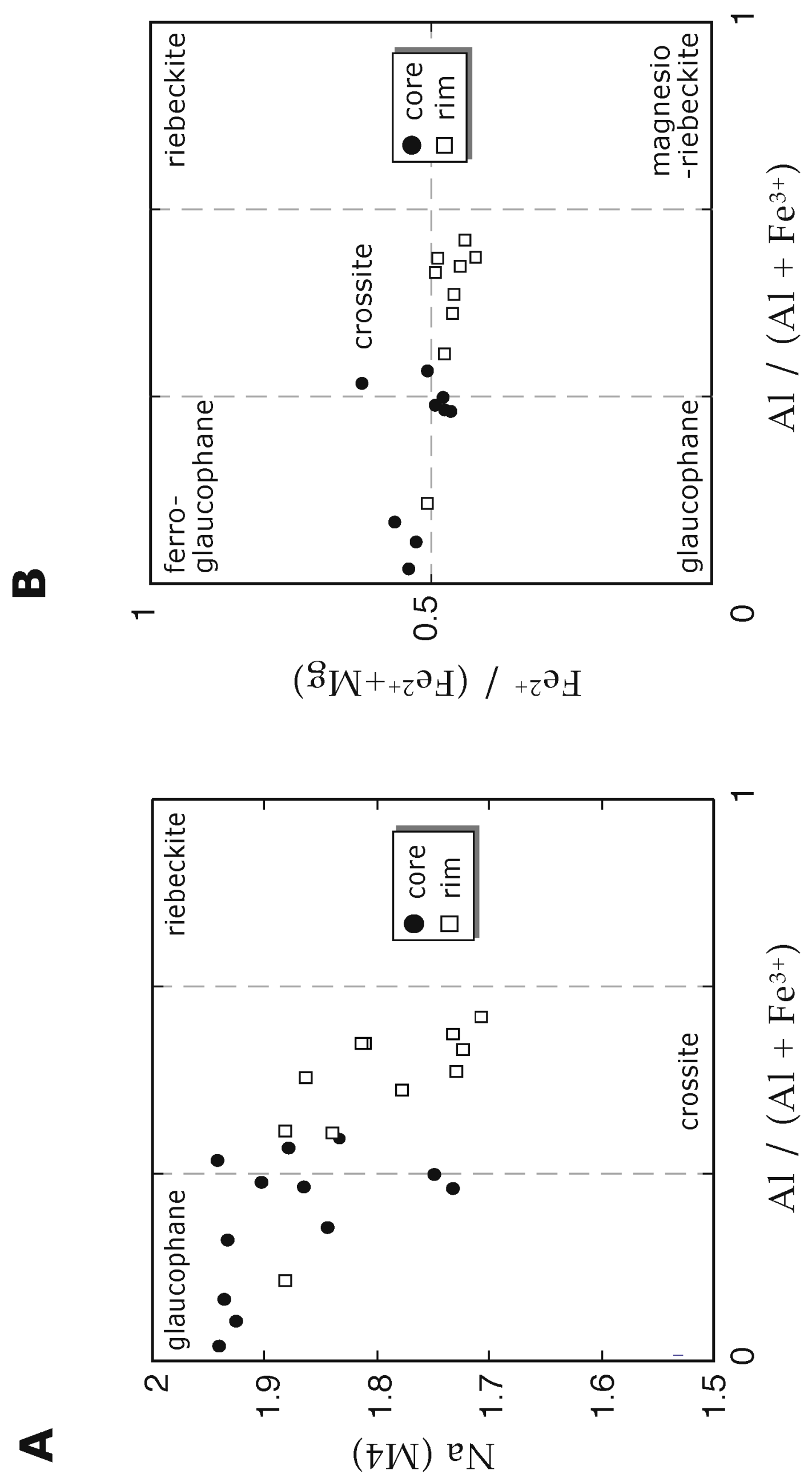


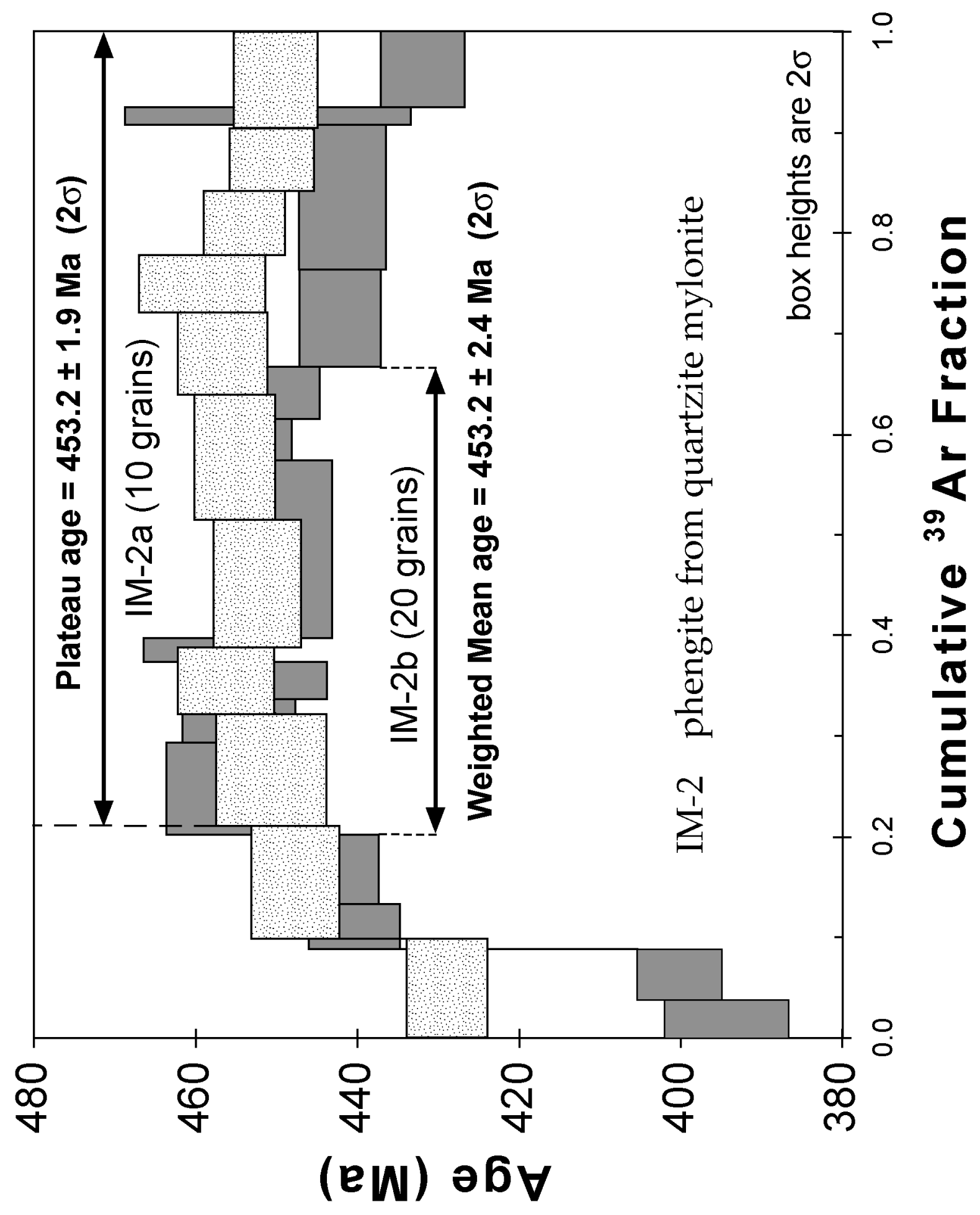




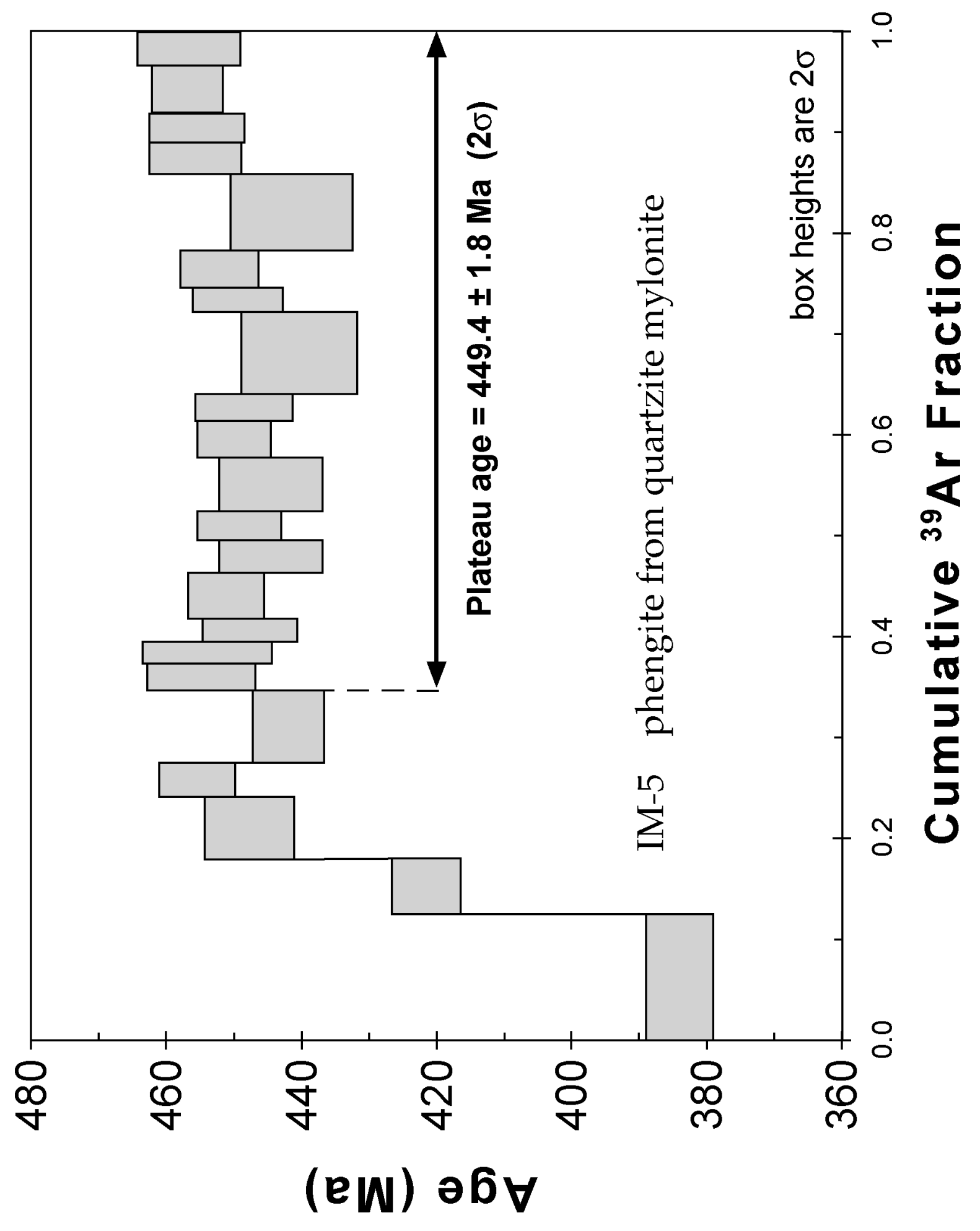




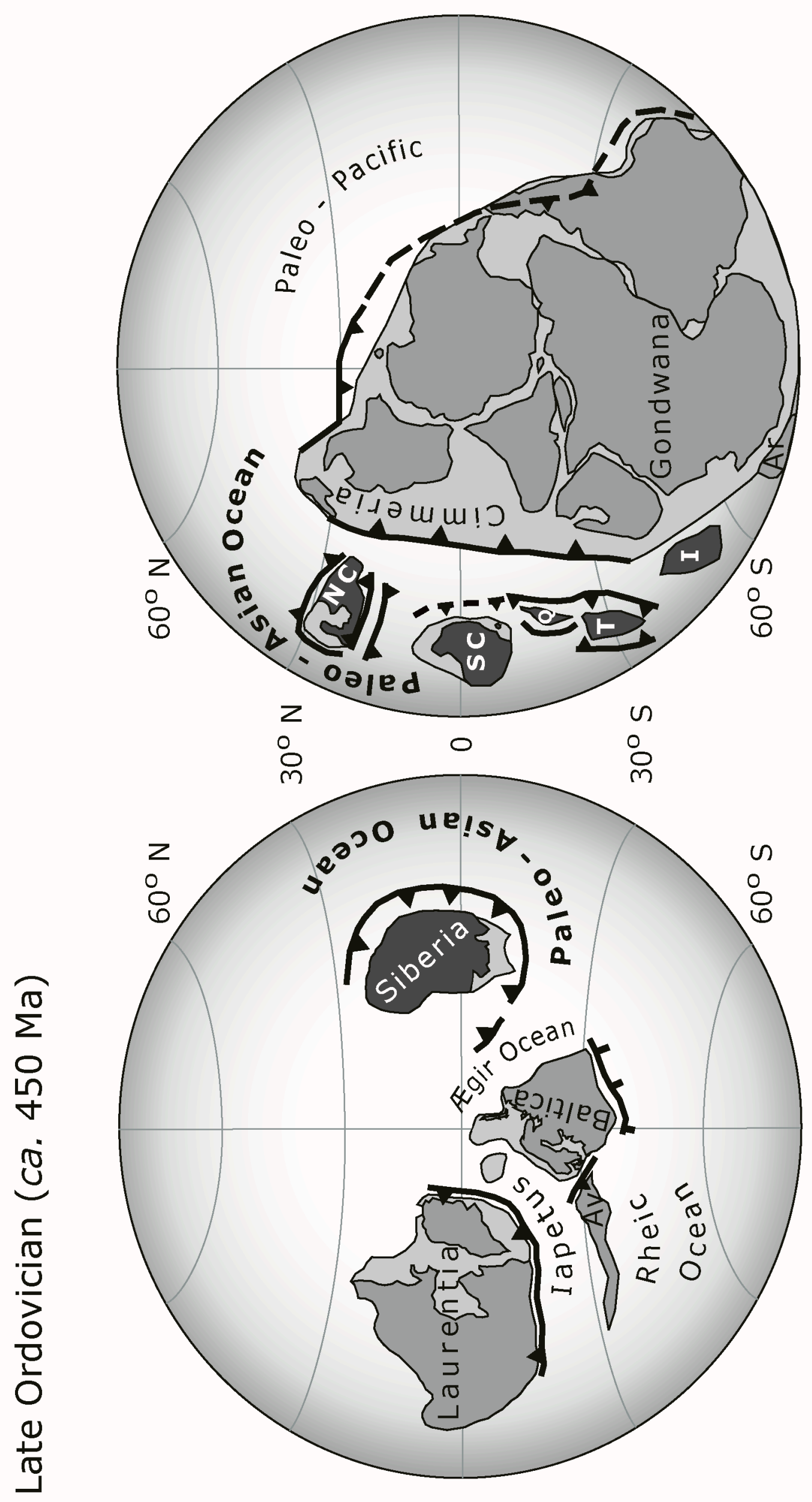


Early Carboniferous (ca. 340 Ma)

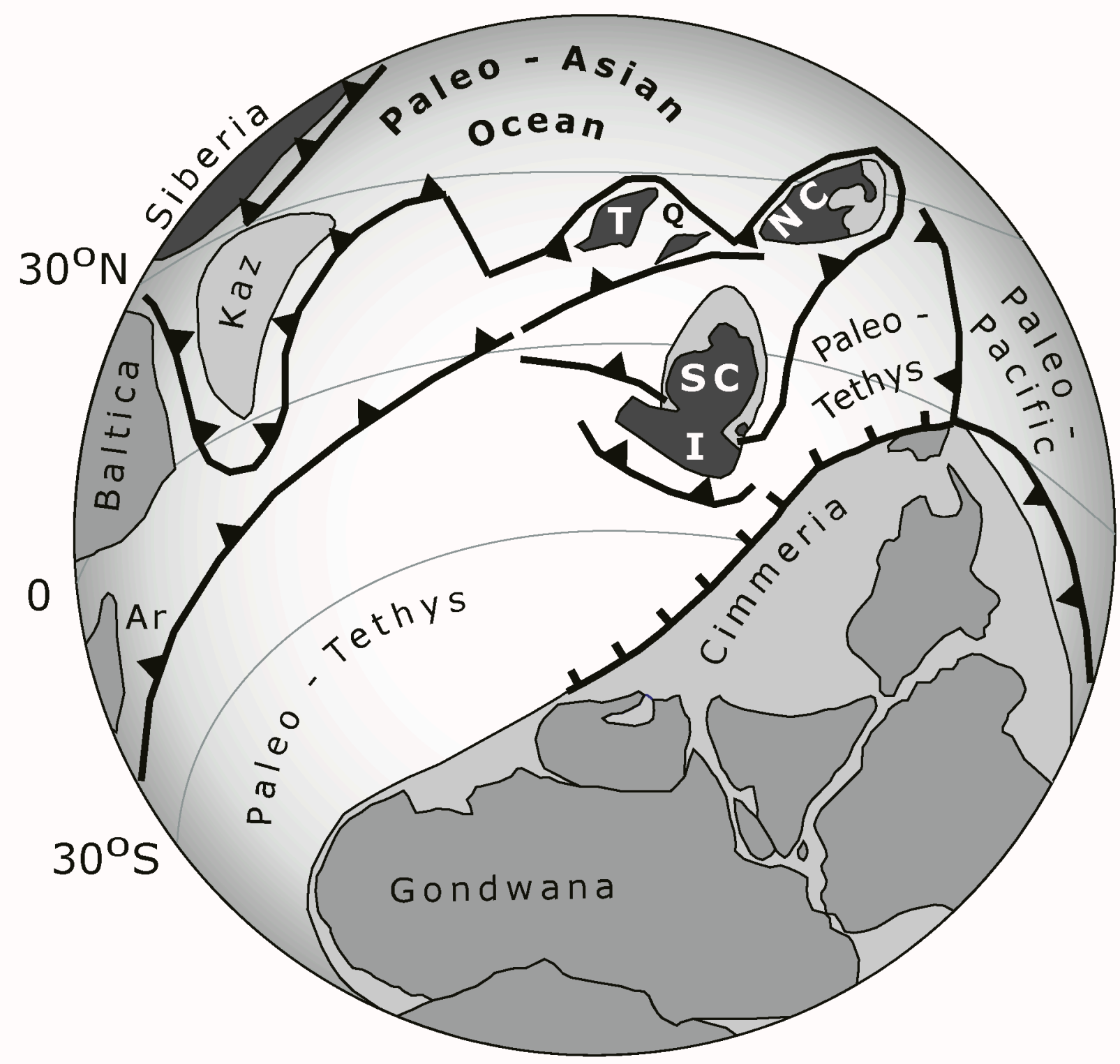




\section{Figure captions}

Fig. 1. Tectonic map of Asia with the main terranes, the Central Asian Organic Belt, and the Solonker suture zone (string of black elongated dots, modified after Badarch and others (2002) and Xiao and others (2004b)). White star indicates Ondor Sum region; numbered stars locations discussed in the text: 1). Sergeevka ophiolite, 2). Jiamusi and SongliaoZhangguangcai blocks, 3). North Qinling belt, 4). Central Tianshan, 5). Western Kunlun range, 6). North Qilian Mountains, 7). Zhuguangshan batholith, 8). Song Chay complex, 9). Dai in Loc and Kontum massifs, 10). South Kitakami terrane, 11). Hida belt, with small stars: main occurrences of the Oeyama ophiolite and correlatives. K: Kyushu; H: Honshu. The boundary between South China and Indochina follows the Song Ma zone, allowing early Paleozoic sedimentary series (Findlay, 1998) and Permian Emeishan flood basalts (Chung and others, 1997) to be on the South China craton for the time slice considered. AT: Altyn Tagh fault; RR: Red River segment of the Ailao Shan-Red River shear zone. Modified after: Chang, 1996; Chung and others, 1997; Arakawa and others, 2000; Jahn and others, 2002; Ota and others, 2002; Wilde and others, 2000; Khain and others, 2003; Song and others, 2003; Jahn, 2004; Jia and others, 2004; Oh and others, 2005). Azimuthal equalarea projection.

Fig. 2. Tectonic sketch map of central Inner Mongolia from which late Mesozoic-Cenozoic strata are omitted for clarity (modified after Xiao and others, 2003). Arrow indicates the sampling area in the Ulan Valley (fig. 3).

Fig. 3. Geological map of the Ondor Sum subduction-accretion complex in the Ulan Valley based on Xiao and others (2003), showing its main litho-tectonic units and structures. Samples for radiometric dating (phengite-bearing quartzite mylonites IM-2 and IM-5) and microprobe analysis (glaucophane-bearing foliated margin of meta-gabbro/leucogabbro IM-19) are indicated. Position indicated in figure 2. The position of the blow-up map of the contact between units 1 and 2 (fig. 5) is outlined. 
Fig. 4. Cartoon-like profiles demonstrating the tectonic evolution of the northern margin of the North China craton in Inner Mongolia (A. Cambrian-Late Ordovician; B. OrdovicianSilurian) in the present-day geographic reference frame, modified after Xiao and others (2003).

Fig. 5. Detailed geological map of the contact zone between the pillow basalts of unit 1 (footwall) and the arc volcanic rocks of unit 2 (hanging wall) of the Ondor Sum subduction-accretion complex in the Ulan Valley. Position indicated in figure 3.

Fig. 6. Photomicrograph of boudinaged augitic (Aug) relics within a sodic-amphibole (Na-Amp) crystal in IM-19, the foliated margin of a meta-gabbro/leucogabbro. Note the filling of pullaparts by amphibole with a crossite composition.

Fig. 7. Composition diagrams for sodic-amphiboles in meta-gabbro/leucogabbro IM-19 from the Ondor Sum subduction-accretion complex in the Ulan Valley. A. Na(M4) versus $\mathrm{Al} /\left(\mathrm{Al}+\mathrm{Fe}^{3+}\right)$ for cores and rims of zoned amphibole crystals, B. $\mathrm{Fe}^{2+} /\left(\mathrm{Fe}^{2+}+\mathrm{Mg}\right)$ versus $\mathrm{Al} /\left(\mathrm{Al}+\mathrm{Fe}^{3+}\right)$ ratios for cores and rims of zoned amphiboles. For EPMA data, see table 1 ; for analytical details, see footnote to table 1.

Fig. 8. ${ }^{40} \mathrm{Ar} /{ }^{39} \mathrm{Ar}$ age spectra of phengite from quartzite mylonite IM-2 obtained by step-heating of about 10 (IM-2a) and 20 (IM-2b) grains with a defocused laser beam.

Fig. 9. ${ }^{40} \mathrm{Ar} /{ }^{39} \mathrm{Ar}$ age spectrum of phengite from quartzite mylonite IM-5 obtained by step-heating of about 90 grains with a defocused laser beam.

Fig. 10. Geodynamic reconstructions of the major lithospheric plates for the Late Ordovician (modified after Li and Powell, 2001). Positions of micro-continents (those discussed in the text are dark shaded) and subduction zones modified mainly after: Pickering and Smith (1995), Li and Powell (2001), Fortey and Cocks (2003), Torsvik and Cocks (2004). Ar = Armorica; Av = Avalonia; I = Indochina; NC = North China Craton; Q = Qaidam-Qilian block; $\mathrm{SC}=$ South China Craton; $\mathrm{T}=$ Tarim . 
Fig. 11. Geodynamic reconstructions of the major lithospheric plates for the Early Carboniferous (modified after Li and Powell, 2001). Positions of micro-continents (those discussed in the text are dark shaded) and subduction zones modified mainly after: Metcalfe (1998), Filippova and others (2001), Li and Powell (2001), Torsvik and Cocks (2004). Ar = Armorica; I = Indochina; Kaz = Kazakhstan; NC = North China Craton; Q = Qaidam-Qilian block; $\mathrm{SC}=$ South China Craton; $\mathrm{T}=$ Tarim . 


\section{Table footnotes}

Table 1

Representative mineral analyses Na-amphibole

\begin{tabular}{|c|c|c|c|c|c|c|c|c|c|c|c|c|c|c|c|}
\hline & Gln & Gln & core & rim & core & rim & rim & core & rim & rim & core & rim & rim & core & rim \\
\hline \multicolumn{16}{|l|}{$\mathrm{wt} \%$} \\
\hline $\mathrm{SiO} 2$ & 55.94 & 57.27 & 56.62 & 55.93 & 54.80 & 55.67 & 55.08 & 56.67 & 56.40 & 55.58 & 56.25 & 57.11 & 56.50 & 56.17 & 54.92 \\
\hline $\mathrm{TiO} 2$ & 0.00 & 0.02 & 0.03 & 0.06 & 0.10 & 0.03 & 0.20 & 0.01 & 0.00 & 0.01 & 0.07 & 0.09 & 0.13 & 0.19 & 0.12 \\
\hline $\mathrm{Al} 2 \mathrm{O} 3$ & 6.81 & 5.86 & 7.04 & 3.78 & 6.20 & 7.98 & 3.35 & 7.12 & 7.08 & 4.31 & 6.29 & 8.48 & 9.20 & 7.45 & 4.36 \\
\hline $\mathrm{FeO}^{*}$ & 17.02 & 18.30 & 17.39 & 18.76 & 20.95 & 16.89 & 19.54 & 16.80 & 17.02 & 20.63 & 18.60 & 16.11 & 15.40 & 17.91 & 20.94 \\
\hline $\mathrm{MnO}$ & 0.15 & 0.19 & 0.16 & 0.19 & 0.15 & 0.22 & 0.25 & 0.19 & 0.12 & 0.21 & 0.11 & 0.09 & 0.15 & 0.15 & 0.23 \\
\hline $\mathrm{MgO}$ & 7.80 & 7.51 & 7.57 & 8.74 & 5.40 & 7.04 & 8.54 & 7.92 & 7.07 & 7.49 & 7.19 & 7.10 & 7.23 & 7.53 & 7.79 \\
\hline $\mathrm{CaO}$ & 0.87 & 0.43 & 0.87 & 1.37 & 0.37 & 0.50 & 1.73 & 1.17 & 0.46 & 0.94 & 0.47 & 0.27 & 0.57 & 0.63 & 1.77 \\
\hline $\mathrm{Na} 2 \mathrm{O}$ & 6.72 & 6.61 & 6.31 & 6.14 & 6.83 & 6.74 & 5.99 & 6.27 & 6.88 & 6.42 & 6.72 & 6.78 & 6.81 & 7.09 & 6.42 \\
\hline $\mathrm{K} 2 \mathrm{O}$ & 0.00 & 0.02 & 0.05 & 0.02 & 0.05 & 0.04 & 0.09 & 0.02 & 0.02 & 0.03 & 0.03 & 0.00 & 0.07 & 0.06 & 0.05 \\
\hline Total & 95.32 & 96.21 & 96.05 & 95.02 & 94.85 & 95.13 & 94.78 & 96.17 & 95.05 & 95.68 & 95.72 & 96.02 & 96.05 & 97.19 & 96.60 \\
\hline \multicolumn{16}{|l|}{ pfu } \\
\hline $\mathrm{Si}$ & 8.084 & 8.195 & 8.098 & 8.140 & 8.107 & 8.049 & 8.095 & 8.088 & 8.182 & 8.095 & 8.118 & 8.131 & 8.052 & 7.988 & 7.979 \\
\hline $\mathrm{Al}(\mathrm{IV})$ & 0.000 & 0.000 & 0.000 & 0.000 & 0.000 & 0.000 & 0.000 & 0.000 & 0.000 & 0.000 & 0.000 & 0.000 & 0.000 & 0.012 & 0.021 \\
\hline $\mathrm{Al}(\mathrm{VI})$ & 1.160 & 0.988 & 1.186 & 0.649 & 1.081 & 1.360 & 0.580 & 1.197 & 1.210 & 0.740 & 1.070 & 1.423 & 1.544 & 1.236 & 0.726 \\
\hline $\mathrm{Ti}$ & 0.000 & 0.002 & 0.004 & 0.007 & 0.011 & 0.004 & 0.023 & 0.002 & 0.000 & 0.001 & 0.007 & 0.009 & 0.014 & 0.021 & 0.013 \\
\hline $\mathrm{Fe} 3+$ & 0.518 & 0.647 & 0.586 & 0.894 & 0.599 & 0.481 & 0.915 & 0.529 & 0.345 & 0.957 & 0.649 & 0.342 & 0.256 & 0.576 & 0.901 \\
\hline $\mathrm{Fe} 2+$ & 1.539 & 1.543 & 1.494 & 1.390 & 1.993 & 1.561 & 1.487 & 1.476 & 1.720 & 1.557 & 1.596 & 1.576 & 1.580 & 1.554 & 1.644 \\
\hline $\mathrm{Mn}$ & 0.018 & 0.023 & 0.020 & 0.024 & 0.019 & 0.026 & 0.031 & 0.023 & 0.014 & 0.026 & 0.013 & 0.010 & 0.018 & 0.018 & 0.029 \\
\hline $\mathrm{Mg}$ & 1.681 & 1.601 & 1.613 & 1.897 & 1.191 & 1.518 & 1.871 & 1.685 & 1.530 & 1.626 & 1.546 & 1.507 & 1.536 & 1.595 & 1.687 \\
\hline $\mathrm{Ca}$ & 0.135 & 0.066 & 0.133 & 0.213 & 0.058 & 0.078 & 0.273 & 0.179 & 0.071 & 0.147 & 0.073 & 0.041 & 0.087 & 0.096 & 0.275 \\
\hline $\mathrm{Na}(\mathrm{M} 4)$ & 1.865 & 1.835 & 1.750 & 1.733 & 1.942 & 1.890 & 1.707 & 1.733 & 1.929 & 1.812 & 1.880 & 1.871 & 1.882 & 1.904 & 1.725 \\
\hline $\mathrm{Na}(\mathrm{A})$ & 0.018 & 0.000 & 0.000 & 0.000 & 0.017 & 0.000 & 0.000 & 0.000 & 0.007 & 0.000 & 0.000 & 0.000 & 0.000 & 0.052 & 0.084 \\
\hline $\mathrm{K}$ & 0.001 & 0.004 & 0.010 & 0.004 & 0.010 & 0.006 & 0.018 & 0.003 & 0.004 & 0.005 & 0.005 & 0.000 & 0.013 & 0.011 & 0.008 \\
\hline
\end{tabular}




$\begin{array}{lrrrrrrrrrrrrrrrr}\text { Total } & 15.019 & 14.904 & 14.892 & 14.950 & 15.027 & 14.975 & 14.998 & 14.915 & 15.011 & 14.965 & 14.958 & 14.912 & 14.982 & 15.063 & 15.092 \\ & & & & & & & & & & & & \\ \text { Alvi+Ti+Fe3+ } & 1.678 & 1.638 & 1.775 & 1.550 & 1.691 & 1.845 & 1.517 & 1.728 & 1.555 & 1.697 & 1.726 & 1.775 & 1.814 & 1.833 & 1.640 \\ \text { XFe3+ } & 0.309 & 0.396 & 0.331 & 0.579 & 0.357 & 0.261 & 0.612 & 0.307 & 0.222 & 0.564 & 0.377 & 0.194 & 0.142 & 0.318 & 0.554 \\ \text { Fe/Mg } & 0.916 & 0.963 & 0.926 & 0.733 & 1.674 & 1.028 & 0.795 & 0.876 & 1.124 & 0.957 & 1.032 & 1.046 & 1.028 & 0.974 & 0.975 \\ \text { XMg } & 0.522 & 0.509 & 0.519 & 0.577 & 0.374 & 0.493 & 0.557 & 0.533 & 0.471 & 0.511 & 0.492 & 0.489 & 0.493 & 0.507 & 0.506 \\ \text { A site } & 0.02 & 0.00 & 0.01 & 0.00 & 0.03 & 0.01 & 0.02 & 0.00 & 0.01 & 0.01 & 0.01 & 0.00 & 0.01 & 0.06 & 0.09\end{array}$

Iron calculated as $\mathrm{FeO}$ cation $(\mathrm{O}=23)$

Tab. 1. Representative electron probe microanalyses of sodic-amphibole (Na-Amp) in meta-gabbro/leucogabbro IM-19 from the Ondor Sum subductionaccretion complex in the Ulan Valley. The analyses were made with a JEOL-8800 electron probe X-ray micro-analyzer (Department of Earth and Planetary Science, Tokyo Institute of Technology), operated at $15 \mathrm{kV}$ with a beam current of $1.20 \times 10^{-8} \AA$ and a $<4 \mu \mathrm{m}$ beam diameter. 


\begin{tabular}{|c|c|c|c|c|c|c|c|c|c|c|}
\hline Phengite & & $\begin{array}{l}\text { Chlorite } \\
\mathrm{wt} \%\end{array}$ & & & $\begin{array}{l}\text { Plagiocl } \\
\mathrm{wt} \%\end{array}$ & & & $\underline{\mathrm{w} t} \%$ & Dolomite-core & Dolomite-rim \\
\hline $\mathrm{SiO} 2$ & 55.86 & & $\mathrm{SiO} 2$ & 28.64 & & $\mathrm{SiO} 2$ & 69.03 & $\mathrm{SiO} 2$ & 0.05 & 0.96 \\
\hline $\mathrm{TiO} 2$ & 0.00 & & $\mathrm{TiO} 2$ & 0.01 & & $\mathrm{TiO} 2$ & 0.00 & $\mathrm{TiO} 2$ & 0.00 & 0.09 \\
\hline $\mathrm{Al} 2 \mathrm{O} 3$ & 21.93 & & $\mathrm{~A} 12 \mathrm{O} 3$ & 17.23 & & $\mathrm{~A} 12 \mathrm{O} 3$ & 19.38 & $\mathrm{Al} 2 \mathrm{O} 3$ & 0.19 & 0.44 \\
\hline $\mathrm{Cr} 2 \mathrm{O} 3$ & 0.03 & & $\mathrm{Cr} 2 \mathrm{O} 3$ & 0.00 & & $\mathrm{Cr} 2 \mathrm{O} 3$ & 0.00 & $\mathrm{Cr} 2 \mathrm{O} 3$ & 0.05 & 0.03 \\
\hline $\mathrm{Fe}-\mathrm{Ox} *$ & 3.70 & $\mathrm{Fe}-\mathrm{Ox} *$ & & 21.95 & $\mathrm{Fe}-\mathrm{Ox}+$ & & 0.03 & $\mathrm{Fe}-\mathrm{Ox} *$ & 5.11 & 7.02 \\
\hline $\mathrm{MnO}$ & 0.00 & & $\mathrm{MnO}$ & 0.43 & & $\mathrm{MnO}$ & 0.00 & $\mathrm{MnO}$ & 0.95 & 1.10 \\
\hline $\mathrm{MgO}$ & 5.15 & & $\mathrm{MgO}$ & 16.98 & & $\mathrm{MgO}$ & 0.01 & $\mathrm{MgO}$ & 11.75 & 17.55 \\
\hline $\mathrm{CaO}$ & 0.05 & & $\mathrm{CaO}$ & 0.06 & & $\mathrm{CaO}$ & 0.06 & $\mathrm{CaO}$ & 34.80 & 29.62 \\
\hline $\mathrm{Na} 2 \mathrm{O}$ & 0.04 & & $\mathrm{Na} 2 \mathrm{O}$ & 0.04 & & $\mathrm{Na} 2 \mathrm{O}$ & 10.71 & $\mathrm{Na} 2 \mathrm{O}$ & 0.10 & 0.04 \\
\hline $\mathrm{K} 2 \mathrm{O}$ & 11.51 & & $\mathrm{~K} 2 \mathrm{O}$ & 0.09 & & $\mathrm{~K} 2 \mathrm{O}$ & 0.05 & $\mathrm{~K} 2 \mathrm{O}$ & 0.00 & 0.00 \\
\hline $\mathrm{P} 2 \mathrm{O} 5$ & 0.00 & & $\mathrm{P} 2 \mathrm{O} 5$ & 0.00 & & $\mathrm{P} 2 \mathrm{O} 5$ & 0.00 & $\mathrm{P} 2 \mathrm{O} 5$ & 0.15 & 0.13 \\
\hline Total & 98.26 & Total & & 85.45 & Total & & 99.28 & Total & 53.15 & 56.98 \\
\hline pfu & & pfu & & & pfu & & & pfu & & \\
\hline $\mathrm{Si}$ & 3.642 & & $\mathrm{Si}$ & 6.293 & & $\mathrm{Si}$ & 3.020 & $\mathrm{Si}$ & 0.021 & 0.340 \\
\hline $\mathrm{Ti}$ & 0.000 & & $\mathrm{Ti}$ & 0.002 & & $\mathrm{Ti}$ & 0.000 & $\mathrm{Ti}$ & 0.000 & 0.025 \\
\hline $\mathrm{Al}(\mathrm{IV})$ & 0.358 & & $\mathrm{Al}(\mathrm{IV})$ & 1.705 & & & & & & \\
\hline $\mathrm{Al}(\mathrm{VI})$ & 1.327 & & $\mathrm{Al}(\mathrm{VI})$ & 2.759 & & & & & & \\
\hline $\mathrm{Al}$ & 1.685 & & $\mathrm{Al}$ & 4.464 & & $\mathrm{Al}$ & 0.999 & $\mathrm{Al}$ & 0.088 & 0.183 \\
\hline $\mathrm{Cr}$ & 0.001 & & $\mathrm{Cr}$ & 0.000 & & $\mathrm{Cr}$ & 0.000 & $\mathrm{Cr}$ & 0.014 & 0.007 \\
\hline $\mathrm{Fe}$ & 0.202 & & $\mathrm{Fe} 2+$ & 4.033 & & $\mathrm{Fe} 3+$ & 0.001 & $\mathrm{Fe}$ & 1.686 & 2.075 \\
\hline $\mathrm{Mn}$ & 0.000 & & $\mathrm{Mn}$ & 0.079 & & $\mathrm{Mn}$ & 0.000 & $\mathrm{Mn}$ & 0.318 & 0.330 \\
\hline $\mathrm{Mg}$ & 0.501 & & $\mathrm{Mg}$ & 5.564 & & $\mathrm{Mg}$ & 0.000 & $\mathrm{Mg}$ & 6.916 & 9.246 \\
\hline $\mathrm{Ca}$ & 0.003 & & $\mathrm{Ca}$ & 0.014 & & $\mathrm{Ca}$ & 0.003 & $\mathrm{Ca}$ & 14.720 & 11.222 \\
\hline $\mathrm{Na}$ & 0.004 & & $\mathrm{Na}$ & 0.017 & & $\mathrm{Na}$ & 0.908 & $\mathrm{Na}$ & 0.074 & 0.024 \\
\hline $\mathrm{K}$ & 0.957 & & $\mathrm{~K}$ & 0.026 & & $\mathrm{~K}$ & 0.003 & $\mathrm{~K}$ & 0.000 & 0.000 \\
\hline $\mathrm{P}$ & 0.000 & & $\mathrm{P}$ & 0.000 & & $\mathrm{P}$ & 0.000 & $\mathrm{P}$ & 0.051 & 0.040 \\
\hline Total & 8.681 & & Total & 20.49 & & Total & 4.935 & Total & 23.888 & 23.492 \\
\hline $\mathrm{Mg} /(\mathrm{Fe}+\mathrm{Mg})$ & 0.713 & $\mathrm{Mg} /(\mathrm{Fe}+\mathrm{Mg})$ & & 0.58 & An & & 0.308 & & & \\
\hline A site & 0.965 & & & & $\mathrm{Ab}$ & & 99.369 & & & \\
\hline $\mathrm{K} /(\mathrm{K}+\mathrm{Na})$ & 0.995 & & & & Or & & 0.324 & & & \\
\hline
\end{tabular}


Fe-Ox* Iron calculated as $\mathrm{FeO}$

Fe-Ox+ $\quad$ Iron calculated as $\mathrm{Fe} 2 \mathrm{O} 3$

Phengite cation $(\mathrm{O}=11)$

Chlorite cation $(\mathrm{O}=28)$

Plagioclase $\quad$ cation $(\mathrm{O}=8)$

Tab. 2. Representative electron probe microanalyses of various minerals in meta-gabbro/leucogabbro IM-19 from the Ondor Sum subduction-accretion complex in the Ulan Valley. Abbreviations according to Kretz (1983); Phn: phengite. Analytical details, see footnote to table 1.

Table 3

${ }^{40} \mathrm{Ar} /{ }^{39} \mathrm{Ar}$ analytical data of phengite from IM-2

\begin{tabular}{|c|c|c|c|c|c|c|c|c|c|}
\hline $\begin{array}{r}\text { power } \\
\text { (watts) }\end{array}$ & cum.39 & Atm. $\%$ & ${ }^{36} \mathrm{Ar} /{ }^{39} \mathrm{Ar}$ & ${ }^{37} \mathrm{Ar} /{ }^{39} \mathrm{Ar}$ & ${ }^{38} \mathrm{Ar} /{ }^{39} \mathrm{Ar}$ & ${ }^{40} \mathrm{Ar} /{ }^{39} \mathrm{Ar}$ & ${ }^{40} \mathrm{Ar} /{ }^{36} \mathrm{Ar}$ & $\begin{array}{l}\text { Age } \\
\text { (Ma) }\end{array}$ & Error \\
\hline \multicolumn{3}{|c|}{ Laser step-heating IM-2a } & 10 grains & & & & & & \\
\hline 0.04 & 0.098 & 0.2 & 0.000620 & 0.012820 & 0.142300 & 78.26 & 126200 & 429.0 & 5.0 \\
\hline 0.06 & 0.210 & 0.4 & 0.001185 & 0.080930 & 0.013180 & 82.17 & 69370 & 447.3 & 5.4 \\
\hline 0.09 & 0.321 & 0.8 & 0.002291 & 0.198100 & 0.011940 & 83.08 & 36260 & 450.2 & 6.8 \\
\hline 0.12 & 0.387 & 0.5 & 0.001500 & 0.234300 & 0.013760 & 83.98 & 55990 & 455.7 & 6.0 \\
\hline 0.15 & 0.515 & 0.2 & 0.000473 & 0.008534 & 0.011600 & 82.88 & 175300 & 451.7 & 5.4 \\
\hline 0.21 & 0.639 & 0.5 & 0.001457 & 0.012630 & 0.012260 & 83.75 & 57480 & 454.6 & 5.0 \\
\hline 0.24 & 0.721 & 0.4 & 0.001132 & 0.009586 & 0.012350 & 83.99 & 74200 & 456.2 & 5.6 \\
\hline 0.27 & 0.778 & 0.7 & 0.002173 & 0.183500 & 0.015870 & 84.77 & 39010 & 458.5 & 7.8 \\
\hline 0.48 & 0.842 & 0.8 & 0.002484 & 0.372000 & 0.014540 & 83.78 & 33730 & 453.4 & 5.0 \\
\hline 0.67 & 0.904 & 0.5 & 0.001424 & 0.027380 & 0.014380 & 82.93 & 58230 & 450.6 & 5.2 \\
\hline
\end{tabular}


Laser step-heating IM-2b

$0.02 \quad 0.059$

20 grains

$\begin{array}{lll}0.05 & 0.138 & 2.1 \\ 0.09 & 0.207 & 1.3\end{array}$

0.00493

0.00535

0.01806

0.19010

72.51

$14710 \quad 394$.

$0.09 \quad 0.207$

0.00347

0.00090

0.03831

0.01120

73.79

$\begin{array}{lll}13800 & 400.2 & 5.2\end{array}$

$\begin{array}{lll}0.12 & 0.313 & 0.3 \\ 0.15 & 0.370 & 1.4\end{array}$

$0.19-0.437$

0.00412

0.01125

0.01135

81.43

81.17

0.00863

85.08

$23490 \quad 440.4 \quad 5.6$

0.00229

0.13870

0.00937

84.02

0.00077

0.03814

0.01113

82.69

0.00215

0.33010

0.01181

84.76

85.82

.16160

83.39

0.00289

0.00132

0.08763

0.01091

83.33

0.01772

0.01161

81.16

0.00203

0.00315

0.01180

81.32

0.856

0.00670

0.13430

0.01203

84.57

$\begin{array}{lll}90180 & 442.8 \quad 5.4\end{array}$

$\begin{array}{lll}20650 & 457.2 & 6.4\end{array}$

$36660 \quad 454.7 \quad 7.0$

$\begin{array}{lll}107300 & 450.4 & 6.6\end{array}$

$\begin{array}{lll}39360 & 458.6 & 7.8\end{array}$

$\begin{array}{lll}7224 & 449.8 & 6.6\end{array}$

$\begin{array}{lll}70850 & 453.2 & 5.0\end{array}$

$\begin{array}{lll}70850 & 453.2 & 5.0 \\ 28850 & 450.5 & 5.8\end{array}$

$\begin{array}{lll}61640 & 442.2 & 5.0\end{array}$

$40100 \quad 441.9 \quad 5.4$

$\begin{array}{rrr}40100 & 441.9 & 5.4 \\ & 451.1 & 17.6\end{array}$

$\begin{array}{lll}0.53 & 0.883 & 2.3 \\ 2.00 & 1.000 & 0.8\end{array}$

0.00214

0.01404

0.01252

79.30

$37090 \quad 432.0 \quad 5.2$

grain cum.39 Atm.

${ }^{36} \mathrm{Ar} /{ }^{39} \mathrm{Ar}$

${ }^{37} \mathrm{Ar} /{ }^{39} \mathrm{Ar}$

${ }^{38} \mathrm{Ar} /{ }^{39} \mathrm{Ar}$

${ }^{40} \mathrm{Ar} /{ }^{39} \mathrm{Ar}$

${ }^{0} \mathrm{Ar} /{ }^{36} \mathrm{Ar} \quad$ Age Error

(Ma)

Total Laser fusion

$\begin{array}{rrrrrrrrrr}1 & 0.090 & 0.7 & 0.00204 & 0.02230 & 0.00713 & 85.53 & 41880 & 462.3 & 6.6 \\ 2 & 0.160 & 7.6 & 0.02290 & 0.06805 & 0.01414 & 88.49 & 3865 & 446.9 & 7.8 \\ 3 & 0.295 & 0.4 & 0.00125 & 0.01491 & 0.00936 & 84.41 & 67320 & 458.0 & 5.2 \\ 4 & 0.421 & 1.0 & 0.00282 & 0.01589 & 0.00852 & 82.57 & 29270 & 446.9 & 5.0 \\ 5 & 0.533 & 1.0 & 0.00277 & 0.09582 & 0.00985 & 83.93 & 30280 & 453.6 & 5.4 \\ 6 & 0.661 & 2.0 & 0.00568 & 0.01567 & 0.01043 & 83.04 & 14610 & 445.1 & 5.2 \\ 7 & 0.776 & 4.2 & 0.01241 & 0.01814 & 0.01130 & 87.55 & 7054 & 457.3 & 5.6 \\ 8 & 0.843 & 0.2 & 0.00067 & 0.03113 & 0.00917 & 82.20 & 122600 & 448.2 & 5.2 \\ 9 & 0.958 & 0.1 & 0.00020 & 0.01818 & 0.00888 & 83.34 & 425500 & 454.4 & 6.2 \\ 10 & 1.000 & 1.5 & 0.00426 & 0.04947 & 0.00853 & 84.68 & 19860 & 455.0 & 8.8\end{array}$


Tab. 3. ${ }^{40} \mathrm{Ar}{ }^{\beta 9} \mathrm{Ar}$ analytical data of phengite from quartzite mylonite IM-2 from the Ondor Sum subduction-accretion complex in the Ulan Valley. a. Stepheating experiment on about 10 (IM-2a) and 20 (IM-2b) grains. b. Total fusion of 10 single grains. ${ }^{40} \mathrm{Ar} *$ is radiogenic argon from natural K-decay; ${ }^{37} \mathrm{Ar},{ }^{38} \mathrm{Ar}$, and ${ }^{39} \mathrm{Ar}$ are $\mathrm{Ca}$-, $\mathrm{Cl}$ - and $\mathrm{K}$-derived argon during irradiation. Uncertainty for ${ }^{40} \mathrm{Ar} *$ and ${ }^{39} \mathrm{Ar}$ volumes is $\pm 5 \%$.

Table 4

${ }^{40} \mathrm{Ar}{ }^{39} \mathrm{Ar}$ analytical data of phengite from IM-5

\begin{tabular}{|c|c|c|c|c|c|c|c|c|c|}
\hline $\begin{array}{l}\text { power } \\
\text { (watts) }\end{array}$ & cum.39 & Atm. $\%$ & ${ }^{36} \mathrm{Ar} /{ }^{39} \mathrm{Ar}$ & ${ }^{37} \mathrm{Ar} /{ }^{39} \mathrm{Ar}$ & ${ }^{38} \mathrm{Ar} r^{39} \mathrm{Ar}$ & ${ }^{40} \mathrm{Ar} /{ }^{39} \mathrm{Ar}$ & ${ }^{40} \mathrm{Ar} /{ }^{36} \mathrm{Ar}$ & $\begin{array}{l}\text { Age } \\
\text { (Ma) }\end{array}$ & Error \\
\hline a. Laser step & heating & & 90 grains & & & & & & \\
\hline 0.02 & 0.125 & 1.8 & 0.00431 & 0.00369 & 0.01313 & 70.18 & 16280 & 383.6 & 5.0 \\
\hline 0.05 & 0.181 & 1.6 & 0.00417 & 0.00829 & 0.01408 & 77.69 & 18620 & 421.1 & 5.0 \\
\hline 0.09 & 0.241 & 1.0 & 0.00271 & 0.00765 & 0.01316 & 82.63 & 30530 & 447.3 & 6.6 \\
\hline 0.12 & 0.277 & 1.3 & 0.00368 & 0.01287 & 0.01307 & 84.44 & 22970 & 454.7 & 5.6 \\
\hline 0.15 & 0.348 & 1.1 & 0.00292 & 0.00651 & 0.01249 & 81.45 & 27930 & 441.3 & 5.2 \\
\hline 0.19 & 0.374 & 1.5 & 0.00434 & 0.01783 & 0.01071 & 84.59 & 19480 & 454.5 & 8.0 \\
\hline 0.22 & 0.396 & 1.9 & 0.00558 & 0.02120 & 0.01294 & 84.74 & 15200 & 453.5 & 9.6 \\
\hline 0.25 & 0.419 & 2.2 & 0.00626 & 0.02029 & 0.01179 & 83.68 & 13370 & 447.4 & 7.0 \\
\hline 0.29 & 0.465 & 1.2 & 0.00329 & 0.01002 & 0.01227 & 83.51 & 25400 & 450.7 & 5.6 \\
\hline 0.32 & 0.498 & 1.5 & 0.00413 & 0.01398 & 0.01275 & 82.40 & 19950 & 444.2 & 7.6 \\
\hline 0.35 & 0.527 & 1.7 & 0.00485 & 0.01607 & 0.01252 & 83.59 & 17230 & 448.9 & 6.2 \\
\hline 0.39 & 0.581 & 0.2 & 0.00059 & 0.00878 & 0.01298 & 81.38 & 138600 & 444.3 & 7.6 \\
\hline 0.43 & 0.618 & 0.3 & 0.00083 & 0.00497 & 0.01367 & 82.56 & 98950 & 449.7 & 5.4 \\
\hline 0.53 & 0.645 & 0.5 & 0.00136 & 0.01773 & 0.01344 & 82.43 & 60830 & 448.3 & 7.2 \\
\hline 2.00 & 0.726 & 0.1 & 0.00026 & 0.00593 & 0.01209 & 80.39 & 309700 & 440.0 & 8.6 \\
\hline 2.50 & 0.750 & 1.8 & 0.00507 & 0.01978 & 0.01273 & 83.63 & 16500 & 448.8 & 6.6 \\
\hline 2.90 & 0.786 & 1.0 & 0.00279 & 0.01333 & 0.01237 & 83.58 & 29950 & 451.8 & 5.8 \\
\hline 3.00 & 0.862 & 0.4 & 0.00099 & 0.00635 & 0.01078 & 80.83 & 81440 & 441.0 & 9.0 \\
\hline 3.50 & 0.893 & 0.2 & 0.00048 & 0.01536 & 0.01185 & 83.55 & 174100 & 455.0 & 6.8 \\
\hline 4.00 & 0.920 & 0.6 & 0.00159 & 0.01755 & 0.01261 & 83.88 & 52750 & 455.0 & 7.0 \\
\hline
\end{tabular}




\begin{tabular}{|c|c|c|c|c|c|c|c|c|c|}
\hline 4.50 & 0.968 & 0.8 & 0.00222 & 0.01000 & 0.01163 & 84.36 & 38020 & 456.4 & 5.2 \\
\hline 5.00 & 1.000 & 1.0 & 0.00285 & 0.00603 & 0.01438 & 84.52 & 29670 & 456.2 & 7.6 \\
\hline 5.50 & 0.421 & 1.0 & 0.00282 & 0.01589 & 0.00852 & 82.57 & 29270 & 446.9 & 5.0 \\
\hline 6.00 & 0.533 & 1.0 & 0.00277 & 0.09582 & 0.00985 & 83.93 & 30280 & 453.6 & 5.4 \\
\hline 6.50 & 0.661 & 2.0 & 0.00568 & 0.01567 & 0.01043 & 83.04 & 14610 & 445.1 & 5.2 \\
\hline 7.20 & 0.776 & 4.2 & 0.01241 & 0.01814 & 0.01130 & 87.55 & 7054 & 457.3 & 5.6 \\
\hline 8.00 & 0.843 & 0.2 & 0.00067 & 0.03113 & 0.00917 & 82.20 & 122600 & 448.2 & 5.2 \\
\hline 9.00 & 0.958 & 0.1 & 0.00020 & 0.01818 & 0.00888 & 83.34 & 425500 & 454.4 & 6.2 \\
\hline 9.90 & 1.000 & 1.5 & 0.00426 & 0.04947 & 0.00853 & 84.68 & 19860 & 455.0 & 8.8 \\
\hline grain & cum.39 & Atm. $\%$ & ${ }^{36} \mathrm{Ar} /{ }^{39} \mathrm{Ar}$ & ${ }^{37} \mathrm{Ar} /{ }^{39} \mathrm{Ar}$ & ${ }^{38} \mathrm{Ar} /{ }^{39} \mathrm{Ar}$ & ${ }^{40} \mathrm{Ar} /{ }^{39} \mathrm{Ar}$ & ${ }^{40} \mathrm{Ar} /{ }^{36} \mathrm{Ar}$ & $\begin{array}{l}\text { Age } \\
(\mathrm{Ma})\end{array}$ & Error \\
\hline \multicolumn{10}{|c|}{ b. Total Laser fusion } \\
\hline 1 & 0.152 & 7.3 & 0.02236 & 0.03831 & 0.01341 & 90.65 & 4055 & 458.0 & 6.8 \\
\hline 2 & 0.438 & 2.5 & 0.00702 & 0.02037 & 0.01328 & 82.91 & 11810 & 442.5 & 5.8 \\
\hline 3 & 0.651 & 17.5 & 0.05936 & 0.02739 & 0.01992 & 100.40 & 1692 & 452.3 & 6.4 \\
\hline 4 & 1.000 & 5.9 & 0.01732 & 0.01669 & 0.01433 & 86.89 & 5016 & 447.1 & 6.0 \\
\hline
\end{tabular}

Tab. 4. $\quad{ }^{40} \mathrm{Ar} /{ }^{39} \mathrm{Ar}$ analytical data of phengite from quartzite mylonite IM-5 from the Ondor Sum subduction-accretion complex in the Ulan Valley. a. Stepheating experiment on about 90 grains. b. Total fusion of 4 single grains. 
Table 5

\begin{tabular}{|c|c|c|c|c|c|}
\hline sample & experiment & & Age and error (Ma) & MSWD & $40 / 36$ ratio \\
\hline \multirow[t]{2}{*}{ IM2 } & Total fusion 10 grains & Weigted mean & $452.8 \pm 5.0$ & & \\
\hline & & Inverse Isochron & $450.4 \pm 3.3$ & 4.4 & $345 \pm 25$ \\
\hline \multirow[t]{3}{*}{ IM2-a } & Stepheating 10 grains & Weigted mean all steps & $450.1 \pm 4.8$ & & \\
\hline & & Plateau ages (79\% 39Ar release) & $453.2 \pm 1.9$ & 0.9 & \\
\hline & & Inverse Isochron plateau steps & $446.8 \pm 10.8$ & 6.3 & $470 \pm 50$ \\
\hline \multirow[t]{3}{*}{ IM2-b } & Stepheating 20 grains & Weigted mean all steps & $442.4 \pm 4.8$ & & \\
\hline & & Plateau ages $(46.6 \%$ 39Ar release $)$ & $453.2 \pm 2.4$ & 1.1 & \\
\hline & & Inverse Isochron plateau steps & $407.3 \pm 49.4$ & 0.3 & $450 \pm 30$ \\
\hline \multirow[t]{4}{*}{ IM5 } & Total fusion 4 grains & Weigted mean & $448.6 \pm 5.2$ & & \\
\hline & Stepheating 90 grains & Weigted mean all steps & $438.4 \pm 4.8$ & & \\
\hline & & Plateau ages (57.3\% 39Ar release) & $449.4 \pm 1.8$ & 1.5 & \\
\hline & & Inverse Isochron plateau steps & $449.3 \pm 6.4$ & 0.3 & $344 \pm 31$ \\
\hline
\end{tabular}

Tab. 5. Summary of the ${ }^{40} \mathrm{Ar} /{ }^{39} \mathrm{Ar}$ age results of phengite IM-2 and IM-5. MSDW $=$ SUMS/(n-2), with SUMS $=$ minimum weighted sum of residuals; $n=$ number of points fitted. $(40 / 36)_{i}$ inverse of the ${ }^{36} \mathrm{Ar} /{ }^{40} \mathrm{Ar}$ intercept in an isotope correlation diagram, that is the composition of the trapped component. 


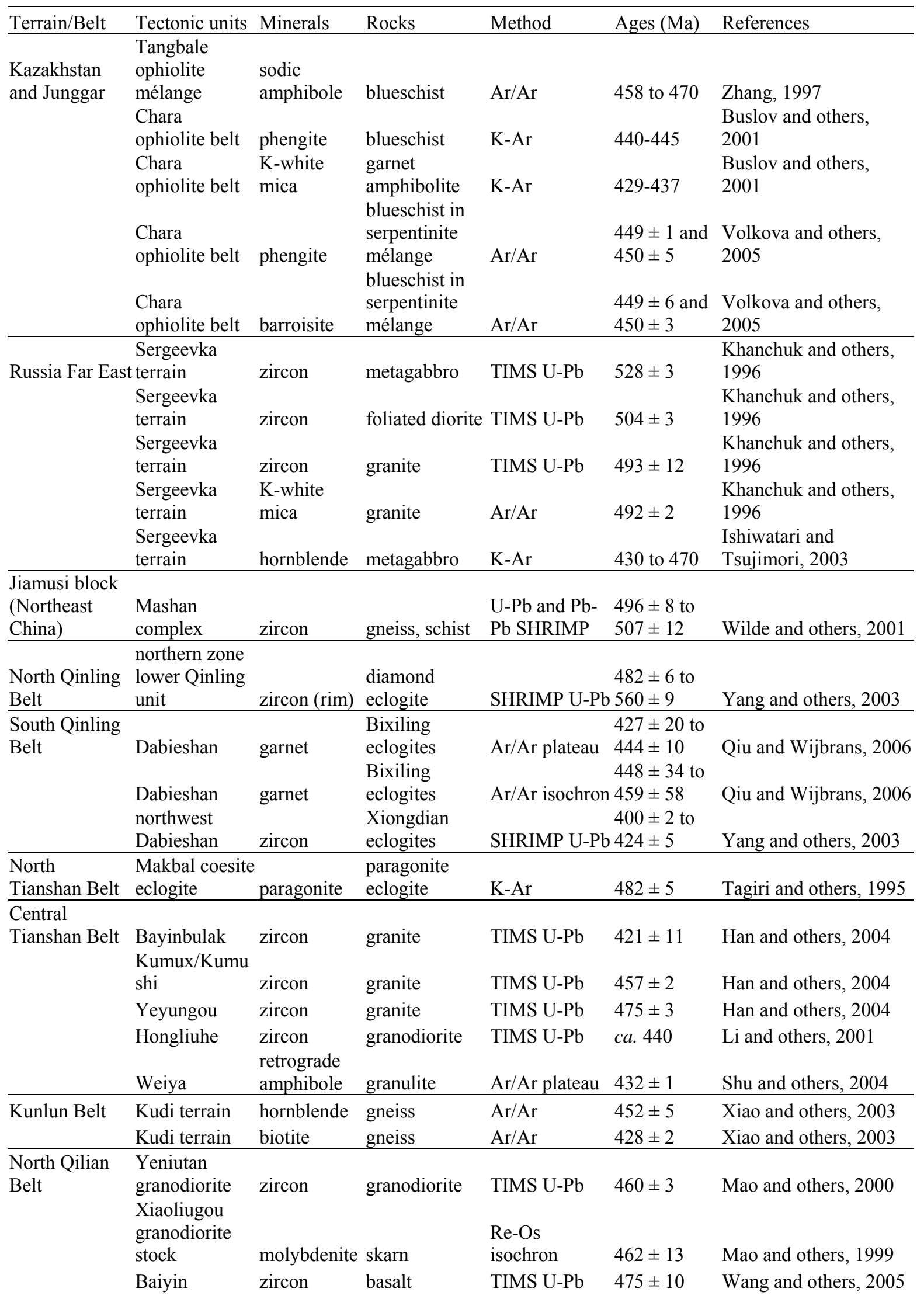




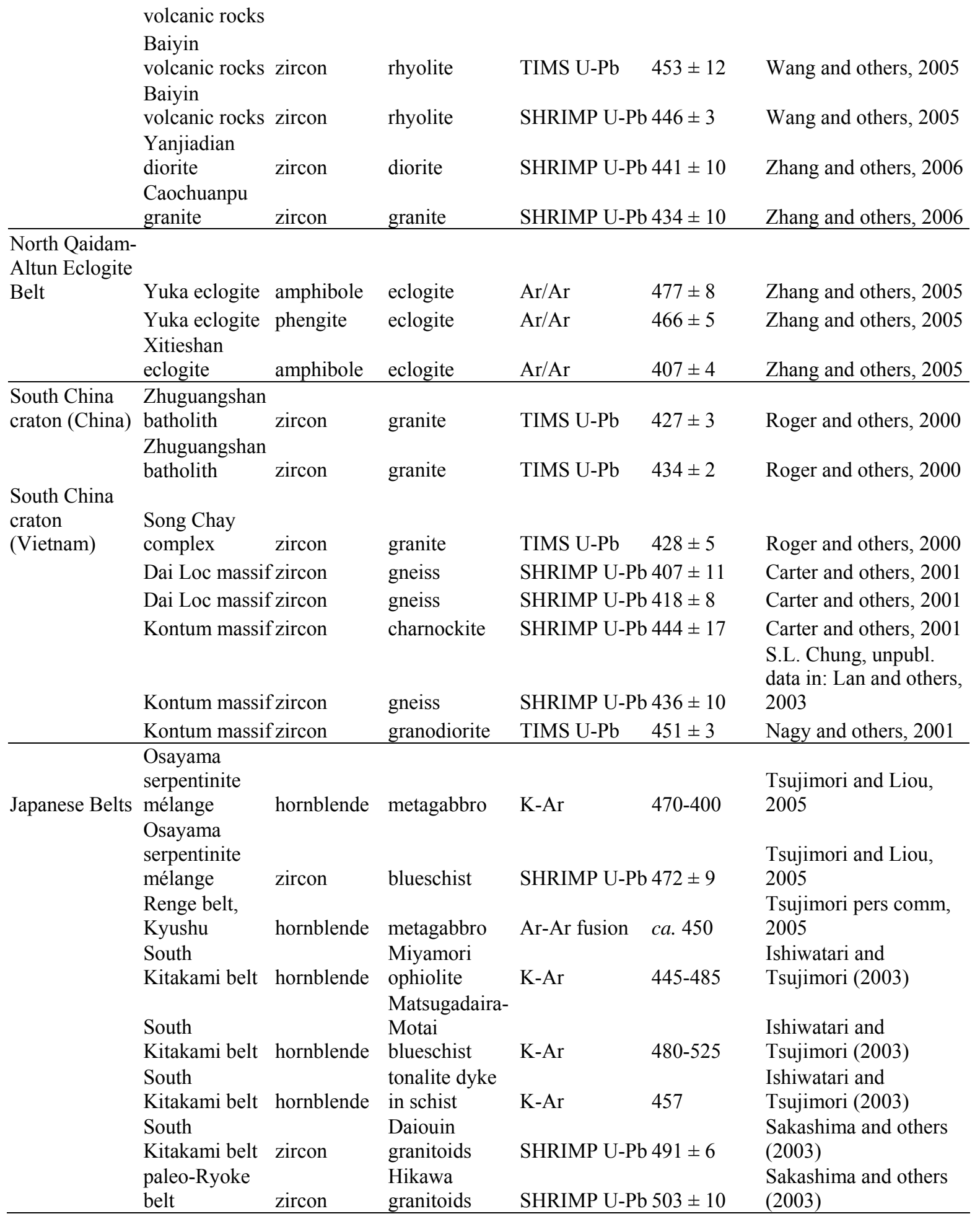

Tab. 6. $\quad$ TIMS $=$ Thermal Ionization Mass Spectrometry; SHRIMP $=$ Sensitive High-Resolution Ion MicroProbe. 
